\title{
Development of Rofecoxib-Based Fluorescent Probes and Investigations on Their Solvatochromism, AIE Activity, Mechanochromism and COX-2-Targeted Bioimaging
}

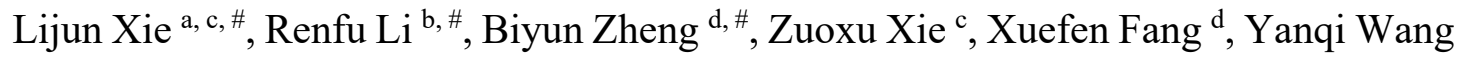

${ }^{\mathrm{b}}$, Gregory D. Cuny ${ }^{\mathrm{c}}$, Zhenli Li ${ }^{\mathrm{e}}$, Bin Lin ${ }^{\mathrm{e}}{ }^{*}$, Xueyuan Chen ${ }^{\mathrm{b},}{ }^{*}$, Ming $\mathrm{Hu}^{\mathrm{c}, *}$

${ }^{a}$ Fujian Provincial Key Laboratory of Screening for Novel Microbial Products, Fujian Institute of Microbiology, Fuzhou, Fujian 350007, P.R. China

${ }^{b}$ CAS Key Laboratory of Design and Assembly of Functional Nanostructures, and Fujian Key Laboratory of Nanomaterials, Fujian Institute of Research on the Structure of Matter, Chinese Academy of Sciences, Fuzhou, Fujian 350002, P.R. China

${ }^{\mathrm{c}}$ Department of Pharmacological and Pharmaceutical Sciences, College of Pharmacy, University of Houston, Houston, TX 77204, United States

${ }^{\mathrm{d}}$ Department of Gastroenterology, Fujian Medical University Union Hospital, Fuzhou, Fujian 350007, P.R. China

e Department of Medicinal Chemistry, School of Pharmaceutical Engineering, Shenyang Pharmaceutical University, Shenyang, Liaoning 110016, P.R. China

\footnotetext{
Author Contributions

${ }^{*}$ Corresponding authors

*E-mail: randybinlin@gmail.com (B.L.); xchen@fjirsm.ac.cn (X.C.); mhu4@uh.edu (M.H.)

${ }^{\#}$ Equal contribution
} 


\section{Table of Contents}

1. Instruments $\ldots \ldots \ldots \ldots \ldots \ldots \ldots \ldots \ldots \ldots \ldots \ldots \ldots \ldots \ldots \ldots, \ldots \ldots \ldots, \ldots \ldots \ldots$

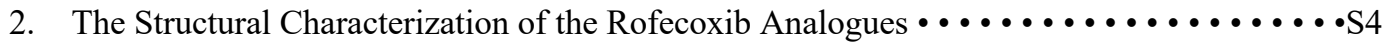

3. The Pictures of the Compounds in Vials and Fluorescent Spectra $\ldots \ldots \ldots \ldots \ldots$...... S14

4. The Photophysical Data of the Rofecoxib Analogues $(\ldots \ldots \ldots \ldots \ldots \ldots \ldots$ S22

5. Cell Viability Assay $\ldots \ldots \ldots \ldots \ldots \ldots \ldots \ldots \ldots \ldots \ldots \ldots \ldots \ldots \ldots \ldots \ldots \ldots \ldots \ldots \ldots \ldots \ldots \ldots$

6. Western Blotting Analysis for Raw264.7 and HeLa Cells COX-2 Protein Expression •..•S23

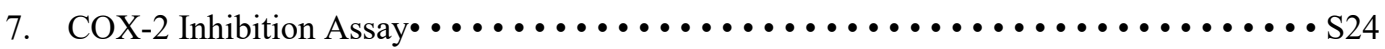

8. Incubation Study of $2 \mathbf{2} 16$ and $\mathrm{COX}-2 \cdot \ldots \ldots \ldots \ldots \ldots \ldots \ldots \ldots \ldots \ldots \ldots \ldots \ldots \ldots \ldots \ldots \ldots \ldots \ldots \ldots \ldots$

9. Cell Culture and Fluorescence Imaging $\ldots \ldots \ldots \ldots \ldots \ldots \ldots \ldots \ldots \ldots \ldots \ldots \ldots \ldots \ldots \ldots$

10. Human Esophageal Tissue Fluorescence Imaging $\ldots \ldots \ldots \ldots \ldots \ldots \ldots \ldots \ldots$ S26

11. Statistics and Reproducibility $\ldots \ldots \ldots \ldots \ldots \ldots \ldots \ldots \ldots \ldots \ldots \ldots \ldots \ldots \ldots \ldots \ldots \ldots \ldots \ldots$

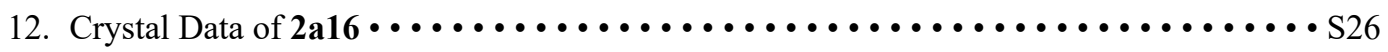

13. Crystal Structure Analysis of 2a16 $\ldots \ldots \ldots \ldots \ldots \ldots \ldots \ldots \ldots \ldots \ldots \ldots \ldots \ldots \ldots \ldots \ldots$

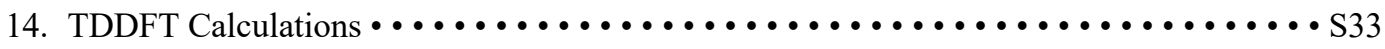

15. Docking Study of $2 \mathbf{a} 16$ in the Active Site of COX-2 $\ldots \ldots \ldots \ldots \ldots \ldots \ldots \ldots \ldots$ S37

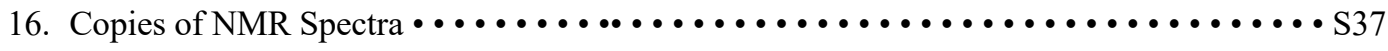

17. References $\ldots \ldots \ldots \ldots \ldots \ldots \ldots \ldots \ldots \ldots \ldots \ldots \ldots \ldots \ldots \ldots \ldots \ldots \ldots \ldots \ldots \ldots$ 


\section{Instruments}

High-resolution mass spectra (HRMS) were obtained at the Mass Spectrometry Service Center of Fujian institute of microbiology on an Agilent 6545 Q-TOF LCMS. Nuclear magnetic resonance (NMR) spectra were obtained on a Bruker UNI-500 and AVII-500B instrument and JEOL 600MHz spectrometers (Framingham, MA) using deuterated solvent (DMSO-d6). Photoluminescence (PL) excitation and emission spectra and PL decays were recorded on the FLS980 spectrometer (Edinburgh, UK) equipped with both continuous Xenon $(450 \mathrm{~W})$. PL, AIE were taken by using a Canon 70D digital camera without using any filter. A differential scanning calorimetry (DSC) trace was obtained on a DSC Q2000 under nitrogen atmosphere. Powder X-ray diffraction (PXRD) patterns were recorded on a Rigaku (Ultima IV) diffractometer. Single crystal X-ray diffraction (SXRD) data were measured on a Bruker Smart APEX CCD-based diffractometer. The absolute PLQYs of sample were measured by employing a standard barium sulfate coated integrating sphere (150 $\mathrm{mm}$ in diameter, Edinburgh, UK) as the sample chamber that was mounted on the FLS980 spectrometer with the entry and output port of the sphere located in $90^{\circ}$ geometry from each other in the plane of the spectrometer. A standard tungsten lamp was used to correct the optical response of the instrument. All the spectral data were recorded at room temperature unless otherwise noted, and corrected for the spectral response of both the spectrometer and the integrating sphere. 


\section{The Structural Characterization of the Rofecoxib Analogues}

2a1: (5Z)-5-(4-cyanobenzylidene)-4-(4-(methylsulfonyl) phenyl)-3-phenylfuran-2(5H)-one<smiles>CS(=O)(=O)c1ccc(C2=C(c3ccccc3)C(=O)O/C2=C\c2ccc(C#N)cc2)cc1</smiles>

Chemical Formula: $\mathrm{C}_{25} \mathrm{H}_{17} \mathrm{NO}_{4} \mathrm{~S}$

Exact Mass: 427.0878

2a1

${ }^{1} \mathrm{H}-\mathrm{NMR}\left(400 \mathrm{MHz}, \mathrm{DMSO}-d_{6}\right) \delta 8.04(\mathrm{~d}, J=8.5 \mathrm{~Hz}, 2 \mathrm{H}), 7.96(\mathrm{~d}, J=8.6 \mathrm{~Hz}, 2 \mathrm{H}), 7.88(\mathrm{~d}, J=8.6 \mathrm{~Hz}$, 2H), $7.67(\mathrm{~d}, J=8.5 \mathrm{~Hz}, 2 \mathrm{H}), 7.35-7.31(\mathrm{~m}, 5 \mathrm{H}), 6.16(\mathrm{~s}, 1 \mathrm{H}), 3.28(\mathrm{~s}, 3 \mathrm{H}) .{ }^{13} \mathrm{C}-\mathrm{NMR}(101 \mathrm{MHz}$, DMSO- $\left.d_{6}\right) \delta 167.7,149.9,149.0,142.3,138.1,135.1,133.2,131.3,130.9,129.9,129.9,129.7,129.07$, 128.9, 128.1, 127.5, 119.2, 111.3, 111.1, 43.7. HR-MS (ESI): calcd for $\mathrm{C}_{25} \mathrm{H}_{17} \mathrm{NNaO}_{4} \mathrm{~S}: 450.0776$ $\left([\mathrm{M}+\mathrm{Na}]^{+}\right)$, found: 450.0772 .

2a2: (5Z)-5-(benzylidene)-4-(4-(methylsulfonyl)phenyl)-3-phenylfuran-2(5H)-one<smiles></smiles>

Chemical Formula: $\mathrm{C}_{24} \mathrm{H}_{18} \mathrm{O}_{4} \mathrm{~S}$

Exact Mass: 402.0926

2a2

$\mathbf{2 a} 2$ was obtained as yellow powder in $86 \%$ yield.

${ }^{1} \mathrm{H}-\mathrm{NMR}\left(400 \mathrm{MHz}, \mathrm{DMSO}-d_{6}\right) \delta 8.04(\mathrm{~d}, J=8.7 \mathrm{~Hz}, 2 \mathrm{H}), 7.79(\mathrm{~d}, J=7.4 \mathrm{~Hz}, 2 \mathrm{H}), 7.67(\mathrm{~d}, J=8.8 \mathrm{~Hz}$, 2H), $7.47-7.39(\mathrm{~m}, 3 \mathrm{H}), 7.38$ - $7.27(\mathrm{~m}, 2 \mathrm{H}), 6.06(\mathrm{~s}, 1 \mathrm{H}), 3.28$ (s, 3H). ${ }^{13} \mathrm{C}-\mathrm{NMR}(101 \mathrm{MHz}$, DMSOd6) $\delta 168.1,149.4,147.9,142.2,135.4,133.4,131.0,130.8,129.8,129.6,129.5,129.2,129.0,128.1$, 126.2, 113.3, 43.7.HR-MS (ESI): calcd for $\mathrm{C}_{24} \mathrm{H}_{18} \mathrm{NaO}_{4} \mathrm{~S}: 425.0823$ ([M+Na $\left.]^{+}\right)$, found: 425.0817.

2a3: (5Z)-5-(4-methylsulfonylbenzylidene)-4-(4-(methylsulfonyl)phenyl)-3-phenylfuran-2(5H)-one 


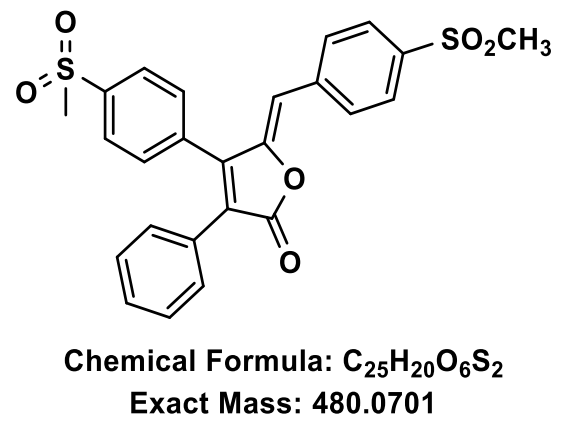

$2 \mathrm{a} 3$

$\mathbf{2 a 3}$ was obtained as yellow powder in $88 \%$ yield.

${ }^{1} \mathrm{H}-\mathrm{NMR}\left(400 \mathrm{MHz}, \mathrm{DMSO}-d_{6}\right) \delta 8.09-8.00(\mathrm{~m}, 4 \mathrm{H}), 7.96(\mathrm{~d}, J=8.5 \mathrm{~Hz}, 2 \mathrm{H}), 7.68(\mathrm{~d}, J=8.5 \mathrm{~Hz}, 2 \mathrm{H})$, $7.39-7.25(\mathrm{~m}, 5 \mathrm{H}), 6.19(\mathrm{~s}, 1 \mathrm{H}), 3.28(\mathrm{~s}, 3 \mathrm{H}), 3.22(\mathrm{~s}, 3 \mathrm{H}) .{ }^{13} \mathrm{C}-\mathrm{NMR}\left(101 \mathrm{MHz}, \mathrm{DMSO}-d_{6}\right) \delta 167.8$, $149.9,149.1,142.3,140.8,138.3,135.1,131.4,130.9,129.9,129.9,129.7,129.0,128.9,128.1,127.9$, 127.5, 111.1, 43.9, 43.8. HR-MS (ESI): calcd for $\mathrm{C}_{25} \mathrm{H}_{20} \mathrm{NaO}_{6} \mathrm{~S}_{2}: 503.0599$ ([M+Na] $\left.]^{+}\right)$, found: 503.0588 . 2a4: (5Z)-5-(2, 6-dimethylbenzylidene)-4-(4-(methylsulfonyl) phenyl)-3-phenylfuran-2(5H)-one

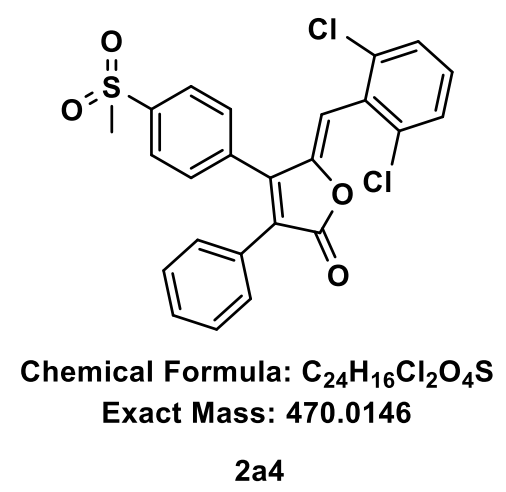

2a4 was obtained as yellow powder in $68 \%$ yield.

${ }^{1} \mathrm{H}-\mathrm{NMR}\left(400 \mathrm{MHz}, \mathrm{DMSO}-d_{6}\right) \delta 8.06(\mathrm{~d}, J=8.3 \mathrm{~Hz}, 2 \mathrm{H}), 7.70(\mathrm{~d}, J=8.3 \mathrm{~Hz}, 2 \mathrm{H}), 7.56(\mathrm{~d}, J=8.1 \mathrm{~Hz}$, 2H), $7.45-7.40(\mathrm{~m}, 3 \mathrm{H}), 7.37-7.30(\mathrm{~m}, 5 \mathrm{H}), 6.16(\mathrm{~s}, 1 \mathrm{H}), 3.28$ (s, 3H). ${ }^{13} \mathrm{C}-\mathrm{NMR}(101 \mathrm{MHz}, \mathrm{DMSO}-$ $\left.d_{6}\right) \delta 167.4,149.9,147.2,142.5,134.7,134.6,134.6,131.5,130.8,130.7,130.0,129.8,129.1,128.9$, 128.7, 128.6, 128.3, 107.7, 43.7. HR-MS (ESI): calcd for $\mathrm{C}_{24} \mathrm{H}_{16} \mathrm{Cl}_{2} \mathrm{NaO}_{4} \mathrm{~S}: 493.0044\left([\mathrm{M}+\mathrm{Na}]^{+}\right)$, found: 493.0034.

2a5: (5Z)-5-(2, 6-dichlorobenzylidene)-4-(4-(methylsulfonyl)phenyl)-3-phenylfuran-2(5H)-one 


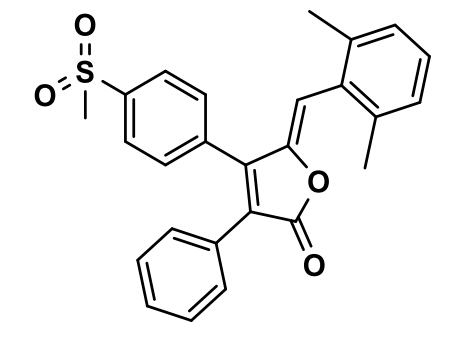

Chemical Formula: $\mathrm{C}_{26} \mathrm{H}_{22} \mathrm{O}_{4} \mathrm{~S}$

Exact Mass: 430.1239

2a5

2a5 was obtained as yellow powder in 73\% yield.

${ }^{1} \mathrm{H}-\mathrm{NMR}\left(400 \mathrm{MHz}, \mathrm{DMSO}-d_{6}\right) \delta 8.04(\mathrm{~d}, J=8.6 \mathrm{~Hz}, 2 \mathrm{H}), 7.73(\mathrm{~d}, J=8.6 \mathrm{~Hz}, 2 \mathrm{H}), 7.37-7.27(\mathrm{~m}, 5 \mathrm{H})$, $7.21-7.01(\mathrm{~m}, 3 \mathrm{H}), 6.38(\mathrm{~s}, 1 \mathrm{H}), 3.27(\mathrm{~s}, 3 \mathrm{H}), 2.20(\mathrm{~s}, 6 \mathrm{H}) .{ }^{13} \mathrm{C}-\mathrm{NMR}\left(101 \mathrm{MHz}, \mathrm{DMSO}-d_{6}\right) \delta 168.0$ $148.4,148.0,142.2,136.8,135.4,132.0,130.8,129.7,129.7,129.0,128.1,127.8,127.2,112.78,43.7$, 20.9. HR-MS (ESI): calcd for $\mathrm{C}_{26} \mathrm{H}_{22} \mathrm{NaO}_{4} \mathrm{~S}: 453.1136$ ([M+Na] $]^{+}$), found: 453.1125 .

2a6: (5Z)-5-(4-hydroxybenzylidene)-4-(4-(methylsulfonyl) phenyl)-3-phenylfuran-2(5H)-one<smiles>CS(=O)(=O)c1ccc(C2=C(c3ccccc3)C(=O)O/C2=C\c2ccc(O)cc2)cc1</smiles>

Chemical Formula: $\mathrm{C}_{24} \mathrm{H}_{18} \mathrm{O}_{5} \mathrm{~S}$

Exact Mass: 418.09

$2 \mathrm{a} 6$

$\mathbf{2 a 6}$ was obtained as yellow powder in $89 \%$ yield.

${ }^{1} \mathrm{H}-\mathrm{NMR}\left(600 \mathrm{MHz}, \mathrm{DMSO}-d_{6}\right) \delta 10.08(\mathrm{~s}, 1 \mathrm{H}), 8.02(\mathrm{~d}, J=8.0 \mathrm{~Hz}, 2 \mathrm{H}), 7.68-7.59$ (m, 4H), $7.32-$ $7.23(\mathrm{~m}, 5 \mathrm{H}), 6.81(\mathrm{~d}, J=8.4 \mathrm{~Hz}, 2 \mathrm{H}), 5.95(\mathrm{~s}, 1 \mathrm{H}), 3.27(\mathrm{~s}, 3 \mathrm{H}) .{ }^{13} \mathrm{C}-\mathrm{NMR}\left(151 \mathrm{MHz}, \mathrm{DMSO}-d_{6}\right) \delta$ $168.2,159.5,149.5,145.7,142.1,135.7,133.2,130.8,129.5,129.3,128.9,128.0,124.6,124.5,116.5$, 114.2, 43.8. HR-MS (ESI): calcd for $\mathrm{C}_{24} \mathrm{H}_{18} \mathrm{O}_{5} \mathrm{SNa}: 441.0773$ ([M+Na $\left.]^{+}\right)$, found: 441.0784 .

2a7: (5Z)-5-(3-hydroxybenzylidene)-4-(4-(methylsulfonyl) phenyl)-3-phenylfuran-2(5H)-one 

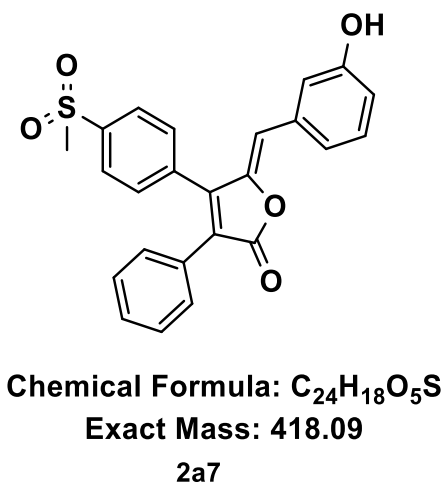

2a7 was obtained as light-yellow powder in $86 \%$ yield.

${ }^{1} \mathrm{H}-\mathrm{NMR}\left(600 \mathrm{MHz}, \mathrm{DMSO}-d_{6}\right) \delta 9.63(\mathrm{~s}, 1 \mathrm{H}), 8.03(\mathrm{~d}, J=7.1 \mathrm{~Hz}, 2 \mathrm{H}), 7.66(\mathrm{~d}, J=7.1 \mathrm{~Hz}, 2 \mathrm{H}), 7.37-$ $7.26(\mathrm{~m}, 6 \mathrm{H}), 7.19(\mathrm{t}, J=7.2 \mathrm{~Hz}, 1 \mathrm{H}), 7.12(\mathrm{~d}, J=7.0 \mathrm{~Hz}, 1 \mathrm{H}), 6.76(\mathrm{~d}, J=7.6 \mathrm{~Hz}, 1 \mathrm{H}), 5.94(\mathrm{~s}, 1 \mathrm{H})$, 3.28 (s, 3H). ${ }^{13} \mathrm{C}-\mathrm{NMR}\left(151 \mathrm{MHz}, \mathrm{DMSO}-d_{6}\right) \delta 168.1,158.1,149.4,147.8,142.1,135.4,134.5,130.8$, 130.3, 129.6, 129.2, 129.0, 128.1, 126.1, 122.5, 117.3, 117.0, 113.6, 43.8.HR-MS (ESI): calcd for $\mathrm{C}_{24} \mathrm{H}_{18} \mathrm{NaO}_{5} \mathrm{~S}: 441.0773\left([\mathrm{M}+\mathrm{Na}]^{+}\right)$, found: 441.0764 .

2a8: (5Z)-5-(2-hydroxybenzylidene)-4-(4-(methylsulfonyl) phenyl)-3-phenylfuran-2(5H)-one<smiles>CS(=O)(=O)c1ccc(C2=C(c3ccccc3)C(=O)O/C2=C\c2ccccc2O)cc1</smiles>

\section{Chemical Formula: $\mathrm{C}_{24} \mathrm{H}_{18} \mathrm{O}_{5} \mathrm{~S}$ \\ Exact Mass: 418.09 \\ 2a8}

$\mathbf{2 a 8}$ was obtained as yellow powder in $91 \%$ yield.

${ }^{1} \mathrm{H}-\mathrm{NMR}\left(600 \mathrm{MHz}, \mathrm{DMSO}-d_{6}\right) \delta 10.09(\mathrm{~s}, 1 \mathrm{H}), 8.05(\mathrm{~d}, J=7.6 \mathrm{~Hz}, 2 \mathrm{H}), 8.01(\mathrm{~d}, J=7.8 \mathrm{~Hz}, 1 \mathrm{H}), 7.67$ $(\mathrm{d}, J=7.6 \mathrm{~Hz}, 2 \mathrm{H}), 7.34-7.26(\mathrm{~m}, 5 \mathrm{H}), 7.18(\mathrm{t}, J=7.6 \mathrm{~Hz}, 1 \mathrm{H}), 6.91(\mathrm{t}, J=7.5 \mathrm{~Hz}, 1 \mathrm{H}), 6.86(\mathrm{~d}, J=$ $8.0 \mathrm{~Hz}, 1 \mathrm{H}), 6.32(\mathrm{~s}, 1 \mathrm{H}), 3.30(\mathrm{~s}, 3 \mathrm{H}) .{ }^{13} \mathrm{C}-\mathrm{NMR}\left(151 \mathrm{MHz}, \mathrm{DMSO}-d_{6}\right) \delta 168.2,156.7,149.5,147.2$, $142.3,135.8,131.6,130.9,130.8,129.5,129.4,129.3,128.9,128.1,125.4,120.3,120.2,116.2,107.7$, 43.6. HR-MS (ESI): calcd for $\mathrm{C}_{24} \mathrm{H}_{18} \mathrm{NaO}_{5} \mathrm{~S}: 441.0773\left([\mathrm{M}+\mathrm{Na}]^{+}\right)$, found: 441.0763 .

2a9: (5Z)-5-(2-hydroxyl-5-fluorobenzylidene)-4-(4-(methylsulfonyl) phenyl)-3-phenylfuran-2(5H)one 


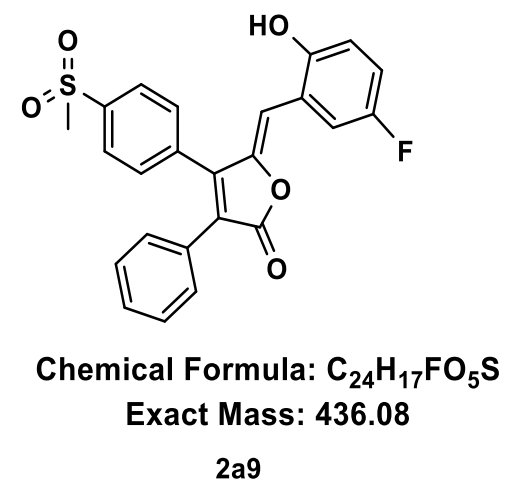

2a9 was obtained as yellow powder in $82 \%$ yield.

${ }^{1} \mathrm{H}-\mathrm{NMR}\left(600 \mathrm{MHz}, \mathrm{DMSO}-d_{6}\right) \delta 10.14(\mathrm{~s}, 1 \mathrm{H}), 8.05(\mathrm{~d}, J=7.6 \mathrm{~Hz}, 2 \mathrm{H}), 7.73(\mathrm{~d}, J=10.1 \mathrm{~Hz}, 1 \mathrm{H}), 7.66$ $(\mathrm{d}, J=7.5 \mathrm{~Hz}, 2 \mathrm{H}), 7.36-7.22(\mathrm{~m}, 5 \mathrm{H}), 7.06(\mathrm{t}, J=8.3 \mathrm{~Hz}, 1 \mathrm{H}), 6.91-6.82(\mathrm{~m}, 1 \mathrm{H}), 6.25(\mathrm{~s}, 1 \mathrm{H}), 3.30$ $(\mathrm{s}, 3 \mathrm{H}) .{ }^{13} \mathrm{C}-\mathrm{NMR}\left(151 \mathrm{MHz}, \mathrm{DMSO}-d_{6}\right) \delta 167.9,156.6,155.0,153.1,149.3,147.9,142.3,135.5,130.8$, $129.6,129.6,129.1,129.0,128.1,126.1,121.1,121.0,118.2,118.0,117.2,117.1,116.0,115.9,106.4$, 43.6. HR-MS (ESI): calcd for $\mathrm{C}_{24} \mathrm{H}_{18} \mathrm{FO}_{5} \mathrm{~S}: 437.0853\left([\mathrm{M}+\mathrm{H}]^{+}\right)$, found: 437.0851 .

2a10: (5Z)-5-(2-hydroxyl-3-methoxylbenzylidene)-4-(4-(methylsulfonyl)phenyl)-3-phenylfuran2(5H)-one<smiles>CCOc1cccc(/C=C2\OC(=O)C(c3ccccc3)=C2c2ccc(S(C)(=O)=O)cc2)c1O</smiles>

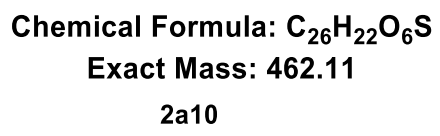

2a10 was obtained as light yellow powder in $81 \%$ yield.

${ }^{1} \mathrm{H}-\mathrm{NMR}\left(600 \mathrm{MHz}, \mathrm{DMSO}-d_{6}\right) \delta 9.10(\mathrm{~s}, 1 \mathrm{H}), 8.05(\mathrm{~d}, J=8.0 \mathrm{~Hz}, 2 \mathrm{H}), 7.68(\mathrm{~d}, J=8.0 \mathrm{~Hz}, 2 \mathrm{H}), 7.62$ $(\mathrm{d}, J=7.9 \mathrm{~Hz}, 1 \mathrm{H}), 7.33-7.26(\mathrm{~m}, 5 \mathrm{H}), 6.95(\mathrm{~d}, J=7.8 \mathrm{~Hz}, 1 \mathrm{H}), 6.85(\mathrm{t}, J=8.0 \mathrm{~Hz}, 1 \mathrm{H}), 6.35(\mathrm{~s}, 1 \mathrm{H})$, $4.03(\mathrm{q}, J=6.8 \mathrm{~Hz}, 2 \mathrm{H}), 3.30(\mathrm{~s}, 3 \mathrm{H}), 1.28(\mathrm{t}, J=6.9 \mathrm{~Hz}, 3 \mathrm{H}) .{ }^{13} \mathrm{C}-\mathrm{NMR}\left(151 \mathrm{MHz}, \mathrm{DMSO}-d_{6}\right) \delta 168.2$, $149.6,147.3,147.1,146.4,142.3,130.8,129.5,129.5,129.3,129.0,128.0,122.3,120.7,120.0,114.7$, 107.7, 64.8, 43.6, 15.0. HR-MS (ESI): Calcd for $\mathrm{C}_{26} \mathrm{H}_{22} \mathrm{NaO}_{6} \mathrm{~S}: 485.1034$ ([M+Na $\left.]^{+}\right)$, found: 485.1020 . 2a11: (5Z)-5-(2-hydroxyl-5chlorobenzylidene)-4-(4-(methylsulfonyl)phenyl)-3-phenylfuran2(5H)-one 
2a11 was obtained as yellow powder in 73\% yield.<smiles>CS(=O)(=O)c1ccc(C2=C(c3ccccc3)C(=O)OC2=Cc2cc(Cl)ccc2O)cc1</smiles>

Chemical Formula: $\mathrm{C}_{24} \mathrm{H}_{17} \mathrm{ClO}_{5} \mathrm{~S}$

Exact Mass: 452.05

2a11

${ }^{1} \mathrm{H}-\mathrm{NMR}\left(600 \mathrm{MHz}, \mathrm{DMSO}-\mathrm{d}_{6}\right) \delta 10.44(\mathrm{~s}, 1 \mathrm{H}), 8.05(\mathrm{~d}, J=7.7 \mathrm{~Hz}, 2 \mathrm{H}), 7.97(\mathrm{~s}, 1 \mathrm{H}), 7.66(\mathrm{~d}, J=7.8$ $\mathrm{Hz}, 2 \mathrm{H}), 7.36-7.26(\mathrm{~m}, 5 \mathrm{H}), 7.23(\mathrm{~d}, J=8.7 \mathrm{~Hz}, 2 \mathrm{H}), 6.88(\mathrm{~d}, J=8.7 \mathrm{~Hz}, 2 \mathrm{H}), 6.22(\mathrm{~s}, 1 \mathrm{H}), 6.22(\mathrm{~s}$, 3H). ${ }^{13} \mathrm{C}-\mathrm{NMR}\left(151 \mathrm{MHz}, \mathrm{DMSO}-d_{6}\right) \delta 167.9,155.5,149.2,148.0,142.3,135.5,130.9,130.8,129.6$, 129.6, 129.1, 129.0, 128.1, 126.2, 123.6, 121.9, 117.8, 105.9, 43.6. HR-MS (ESI): calcd for $\mathrm{C}_{24} \mathrm{H}_{17} \mathrm{ClNaO}_{5} \mathrm{~S}: 475.0377\left([\mathrm{M}+\mathrm{Na}]^{+}\right)$, found: 475.0372.

2a12: (5Z)-5-(4-(dimethylamino)benzylidene)-4-(4-(methylsulfonyl)phenyl)-3-phenylfuran-2(5H)one<smiles>CN(C)c1ccc(/C=C2\OC(=O)C(c3ccccc3)=C2c2ccc(S(C)(=O)=O)cc2)cc1</smiles>

Chemical Formula: $\mathrm{C}_{26} \mathrm{H}_{23} \mathrm{NO}_{4} \mathrm{~S}$

Exact Mass: 445.13

2a12

2 a12 was obtained as yellow powder in $86 \%$ yield.

${ }^{1} \mathrm{H}-\mathrm{NMR}\left(600 \mathrm{MHz}, \mathrm{DMSO}-d_{6}\right) \delta 8.01(\mathrm{~d}, J=7.8 \mathrm{~Hz}, 2 \mathrm{H}), 7.69-7.59(\mathrm{~m}, 4 \mathrm{H}), 7.27(\mathrm{~s}, 5 \mathrm{H}), 6.72(\mathrm{~d}, J$ $=8.0 \mathrm{~Hz}, 2 \mathrm{H}), 5.93(\mathrm{~s}, 1 \mathrm{H}), 3.28(\mathrm{~s}, 3 \mathrm{H}), 2.96(\mathrm{~s}, 3 \mathrm{H}) \cdot{ }^{13} \mathrm{C}-\mathrm{NMR}\left(151 \mathrm{MHz}, \mathrm{DMSO}-d_{6}\right) \delta 168.3,151.3$, $149.3,144.5,141.9,136.0,132.9,130.8,129.8,129.4,129.0,128.9,128.0,122.8,120.9,115.3,112.5$, 43.8. HR-MS (ESI): calcd for: $446.1426\left([\mathrm{M}+\mathrm{H}]^{+}\right)$, found:446.1419.Chemical Formula: $\mathrm{C}_{26} \mathrm{H}_{24} \mathrm{NO}_{4} \mathrm{~S}$ Exact Mass: 446.1426

2a13: (5Z)-4-(4-(methylsulfonyl)phenyl)-3-phenyl-5-(4-(pyrrolidin-1-yl)benzylidene)furan-2(5H)one 


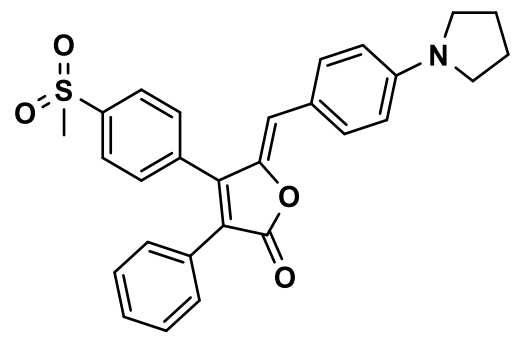

Chemical Formula: $\mathrm{C}_{28} \mathrm{H}_{25} \mathrm{NO}_{4} \mathrm{~S}$

Exact Mass: 471.15

2a13

$\mathbf{2 a 1 3}$ was obtained as red powder in $78 \%$ yield.

${ }^{1} \mathrm{H}-\mathrm{NMR}\left(600 \mathrm{MHz}, \mathrm{DMSO}-d_{6}\right) \delta 8.01(\mathrm{~d}, J=8.0 \mathrm{~Hz}, 2 \mathrm{H}), 7.63(\mathrm{~d}, J=6.9 \mathrm{~Hz}, 4 \mathrm{H}), 7.34-7.18(\mathrm{~m}, 5 \mathrm{H})$, $6.57(\mathrm{~d}, J=8.6 \mathrm{~Hz}, 2 \mathrm{H}), 5.92(\mathrm{~s}, 1 \mathrm{H}), 3.31-3.20(\mathrm{~m}, 7 \mathrm{H}), 1.96-1.89(\mathrm{~m}, 4 \mathrm{H}) .{ }^{13} \mathrm{C}-\mathrm{NMR}(151 \mathrm{MHz}$, DMSO-d $\left.{ }_{6}\right) \delta 168.3,149.3,148.8,144.1,141.9,136.1,135.3,133.1,130.8,129.9,129.4,128.9,128.0$, 122.4, 120.5, 115.7, 112.5, 47.7, 43.8, 25.4. HR-MS (ESI): calcd for $\mathrm{C}_{28} \mathrm{H}_{25} \mathrm{NNaO}_{4} \mathrm{~S}: 472.1577\left([\mathrm{M}+\mathrm{H}]^{+}\right)$, found: 472.1574 .

2a14: (5Z)-5-(4-(4-methylpiperazin-1-yl)benzylidene)-4-(4-(methylsulfonyl)phenyl)-3-phenylfuran-2(5H)-one

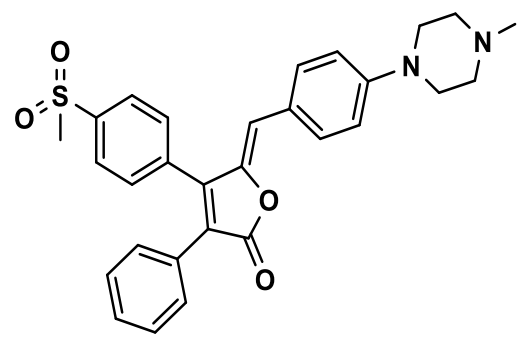

Chemical Formula: $\mathrm{C}_{29} \mathrm{H}_{28} \mathrm{~N}_{2} \mathrm{O}_{4} \mathrm{~S}$

Exact Mass: $\mathbf{5 0 0 . 1 8}$

2a14

$\mathbf{2 a 1 4}$ was obtained as orange powder in $72 \%$ yield.

${ }^{1} \mathrm{H}-\mathrm{NMR}\left(600 \mathrm{MHz}, \mathrm{DMSO}-d_{6}\right) \delta 8.01(\mathrm{~s}, 2 \mathrm{H}), 7.63(\mathrm{~d}, J=7.7 \mathrm{~Hz}, 2 \mathrm{H}), 7.27(\mathrm{~s}, 5 \mathrm{H}), 6.95(\mathrm{~s}, 2 \mathrm{H}), 5.94$ (s, 1H), $3.30-3.19(\mathrm{~m}, 8 \mathrm{H}), 2.38(\mathrm{~s}, 3 \mathrm{H}), 2.17$ (s, 3H). ${ }^{13} \mathrm{C}-\mathrm{NMR}\left(151 \mathrm{MHz}, \mathrm{DMSO}-d_{6}\right) \delta 168.2,151.7$, $149.4,145.2,142.0,135.9,132.7,130.8,129.7,129.4,129.1,128.9,128.0,123.6,123.2,123.0,114.8$, 114.6, 54.8, 47.1, 46.2, 43.8 .

HR-MS (ESI): calcd for $\mathrm{C}_{29} \mathrm{H}_{29} \mathrm{~N}_{2} \mathrm{O}_{4} \mathrm{~S}: 501.1848\left([\mathrm{M}+\mathrm{H}]^{+}\right)$, found: 501.1834 .

2a15: (5Z)-4-(4-(methylsulfonyl)phenyl)-3-phenyl-5-(2-(pyrrolidin-1-yl)benzylidene)furan-2(5H)one 


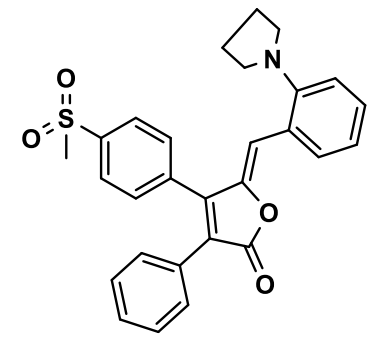

Chemical Formula: $\mathrm{C}_{28} \mathrm{H}_{25} \mathrm{NO}_{4} \mathrm{~S}$

Exact Mass: 471.1504

$2 a 15$

$\mathbf{2 a 1 5}$ was obtained as orange powder in $71 \%$ yield.

${ }^{1} \mathrm{H}-\mathrm{NMR}\left(400 \mathrm{MHz}, \mathrm{DMSO}-d_{6}\right) \delta 8.05(\mathrm{~d}, J=8.7 \mathrm{~Hz}, 2 \mathrm{H}), 7.85(\mathrm{~d}, J=9.9 \mathrm{~Hz}, 1 \mathrm{H}), 7.69(\mathrm{~d}, J=8.7 \mathrm{~Hz}$, 2H), $7.37-7.28(\mathrm{~m}, 5 \mathrm{H}), 7.25-7.14(\mathrm{~m}, 1 \mathrm{H}), 6.99-6.86(\mathrm{~m}, 2 \mathrm{H}), 6.02(\mathrm{~s}, 1 \mathrm{H}), 3.28(\mathrm{~s}, 3 \mathrm{H}), 3.11-$ $2.98(\mathrm{~m}, 4 \mathrm{H}), 1.75-1.71(\mathrm{~m}, 4 \mathrm{H}) .{ }^{13} \mathrm{C}-\mathrm{NMR}\left(101 \mathrm{MHz}, \mathrm{DMSO}-d_{6}\right) \delta 168.3,150.3,149.5,146.5,142.2$, 136.0, 131.6, 130.7, 130.6, 129.4, 129.4, 129.0, 128.0, 124.9, 123.0, 120.6, 116.8, 112.3, 52.6, 43.7, 24.9. HR-MS (ESI): calcd for $\mathrm{C}_{25} \mathrm{H}_{20} \mathrm{NaO}_{6} \mathrm{~S}: 471.0878\left([\mathrm{M}+\mathrm{Na}]^{+}\right)$, found: 471.0863 .

2a16: (Z)-4-(4-(methylsulfonyl)phenyl)-5-(2-morpholinobenzylidene)-3-phenylfuran-2(5H)-one

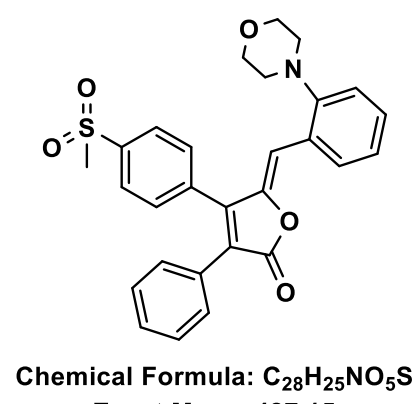

Exact Mass: 487.15

$2 \mathrm{a} 16$

2a16 was obtained as yellow powder in $76 \%$ yield.

${ }^{1} \mathrm{H}-\mathrm{NMR}\left(600 \mathrm{MHz}, \mathrm{DMSO}-d_{6}\right) \delta 8.10(\mathrm{~d}, J=7.3 \mathrm{~Hz}, 2 \mathrm{H}), 8.01(\mathrm{~d}, J=7.3 \mathrm{~Hz}, 1 \mathrm{H}), 7.71(\mathrm{~d}, J=7.3 \mathrm{~Hz}$, 2H), $7.38-7.28(\mathrm{~m}, 6 \mathrm{H}), 7.17(\mathrm{t}, J=6.9 \mathrm{~Hz}, 1 \mathrm{H}), 7.08(\mathrm{~d}, J=7.6 \mathrm{~Hz}, 1 \mathrm{H}), 6.18(\mathrm{~s}, 1 \mathrm{H}), 3.43(\mathrm{~s}, 4 \mathrm{H})$, 3.27 (s, 3H), $2.77(\mathrm{~s}, 4 \mathrm{H}) .{ }^{13} \mathrm{C}-\mathrm{NMR}\left(151 \mathrm{MHz}, \mathrm{DMSO}-d_{6}\right) \delta 168.2,152.5,149.8,148.0,142.25,136.1$, $131.1,131.0,130.7,129.6,129.4,129.2,129.0,128.1,126.5,125.3,123.9,119.7,109.5,66.9,53.2,43.8$. HR-MS (ESI): calcd for $\mathrm{C}_{28} \mathrm{H}_{25} \mathrm{NNaO}_{5} \mathrm{~S}: 510.1351$ ([M+Na $]^{+}$), found: 510.1357 .

2a17: (Z)-4-(4-(methylsulfonyl)phenyl)-5-(4-morpholinobenzylidene)-3-phenylfuran-2(5H)-One 


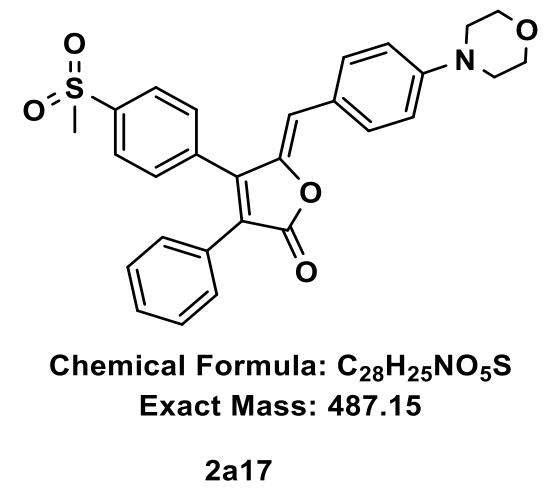

2a17 was obtained as red powder in $89 \%$ yield.

${ }^{1} \mathrm{H}-\mathrm{NMR}\left(400 \mathrm{MHz}, \mathrm{DMSO}-d_{6}\right) \delta 8.02(\mathrm{~d}, J=8.5 \mathrm{~Hz}, 2 \mathrm{H}), 7.67(\mathrm{~d}, J=9.1 \mathrm{~Hz}, 2 \mathrm{H}), 7.63(\mathrm{~d}, J=8.6 \mathrm{~Hz})$, $7.32-7.25(\mathrm{~m}, 5 \mathrm{H}), 6.97(\mathrm{~d}, J=9.2 \mathrm{~Hz}, 2 \mathrm{H}), 5.95(\mathrm{~s}, 1 \mathrm{H}), 3.71-3.66(\mathrm{~m}, 4 \mathrm{H}), 3.28(\mathrm{~s}, 3 \mathrm{H}), 3.23-3.19$ $(\mathrm{m}, 4 \mathrm{H}) .{ }^{13} \mathrm{C}-\mathrm{NMR}\left(101 \mathrm{MHz}, \mathrm{DMSO}-d_{6}\right) \delta 168.2,151.8,149.4,145.47$ 142.0 $135.8,132.6,130.8,129.6$, 129.5, 129.2, 128.9, 128.0, 123.8, 123.5, 114.6, 114.5, 66.4, 47.4, 43.8. HR-MS (ESI): calcd for $\mathrm{C}_{28} \mathrm{H}_{26} \mathrm{NO}_{5} \mathrm{~S}: 488.1532\left([\mathrm{M}+\mathrm{H}]^{+}\right)$, found: 488.1523.

2b1: (Z)-5-(4-hydroxybenzylidene)-3-(4-methoxyphenyl)-4-(4-(methylsulfonyl)phenyl)furan2(5H)-one

2b1 was obtained as yellow powder in $89 \%$ yield.

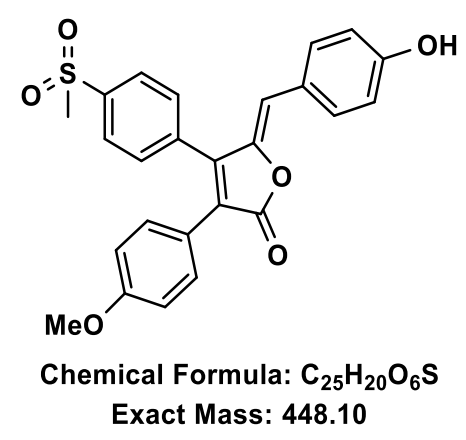

2b1

${ }^{1} \mathrm{H}-\mathrm{NMR}\left(600 \mathrm{MHz}, \mathrm{DMSO}-d_{6}\right) \delta 10.04(\mathrm{~s}, 1 \mathrm{H}), 8.03(\mathrm{~d}, J=7.2 \mathrm{~Hz}, 2 \mathrm{H}), 7.64(\mathrm{~s}, 4 \mathrm{H}), 7.23(\mathrm{~d}, J=8.1$ $\mathrm{Hz}, 2 \mathrm{H}), 6.87(\mathrm{~d}, J=8.0 \mathrm{~Hz}, 2 \mathrm{H}), 6.80(\mathrm{~d}, J=7.7 \mathrm{~Hz}, 2 \mathrm{H}), 5.88(\mathrm{~s}, 1 \mathrm{H}), 3.70(\mathrm{~s}, 3 \mathrm{H}), 3.28(\mathrm{~s}, 3 \mathrm{H}) .{ }^{13} \mathrm{C}-$ NMR (151 MHz,DMSO-d6) $\delta 168.4,160.1,159.3,147.7,145.8,142.0,136.1,133.0,130.8,130.8,128.1$, 124.7, 124.0, 121.6, 116.5, 114.5, 113.4, 55.7, 43.8. HR-MS (ESI): calcd for $\mathrm{C}_{25} \mathrm{H}_{20} \mathrm{NaO}_{6} \mathrm{~S}: 471.0878$ $\left([\mathrm{M}+\mathrm{Na}]^{+}\right)$, found: 471.0868 .

2b2: (Z)-5-(3-hydroxybenzylidene)-3-(4-methoxyphenyl)-4-(4-(methylsulfonyl)phenyl)furan2(5H)-one 
$\mathbf{2 b 2}$ was obtained as yellow powder in $86 \%$ yield.

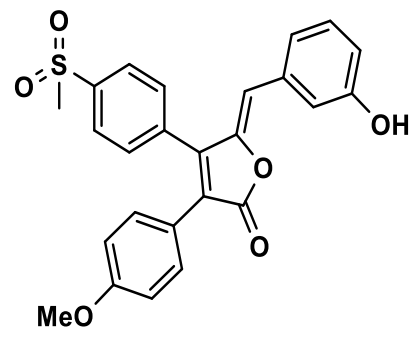

Chemical Formula: $\mathrm{C}_{25} \mathrm{H}_{20} \mathrm{O}_{6} \mathrm{~S}$

Exact Mass: $\mathbf{4 4 8 . 1 0}$

$2 b 2$

${ }^{1} \mathrm{H}-\mathrm{NMR}\left(600 \mathrm{MHz}, \mathrm{DMSO}-d_{6}\right) \delta 9.61(\mathrm{~s}, 1 \mathrm{H}), 8.04(\mathrm{~d}, J=7.9 \mathrm{~Hz}, 2 \mathrm{H}), 7.66(\mathrm{~d}, J=7.9 \mathrm{~Hz}, 2 \mathrm{H}), 7.31$ (s, 1H), $7.25(\mathrm{~d}, J=8.4 \mathrm{~Hz}, 2 \mathrm{H}), 7.18(\mathrm{t}, J=7.8 \mathrm{~Hz}, 1 \mathrm{H}), 7.09(\mathrm{~d}, J=7.6 \mathrm{~Hz}, 1 \mathrm{H}), 6.88(\mathrm{~d}, J=8.4 \mathrm{~Hz}$, 2H), $6.74(\mathrm{~d}, J=7.9 \mathrm{~Hz}, 1 \mathrm{H}), 5.87(\mathrm{~s}, 1 \mathrm{H}), 3.70(\mathrm{~s}, 3 \mathrm{H}), 3.28(\mathrm{~s}, 3 \mathrm{H}) .{ }^{13} \mathrm{C}-\mathrm{NMR}\left(151 \mathrm{MHz}, \mathrm{DMSO}-d_{6}\right)$ $\delta 168.3,160.3,158.1,147.9,147.5,142.0,135.8,134.6,131.0,130.8,130.3,128.2,125.5,122.4,121.4$, 117.1, 116.9, 114.5, 112.8, 55.7, 43.8. HR-MS (ESI): calcd for $\mathrm{C}_{25} \mathrm{H}_{20} \mathrm{NaO}_{6} \mathrm{~S}: 471.0878\left([\mathrm{M}+\mathrm{Na}]^{+}\right)$, found: 471.0871 .

2b3: (Z)-5-(2-hydroxybenzylidene)-3-(4-methoxyphenyl)-4-(4-(methylsulfonyl)phenyl)furan2(5H)-one

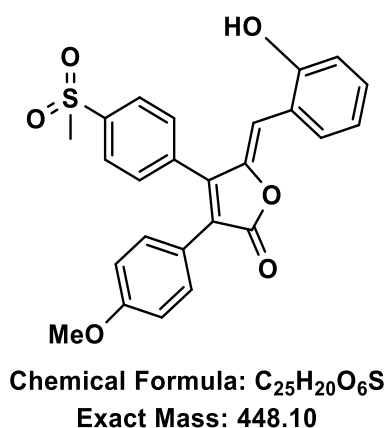

$2 b 3$

$\mathbf{2 b 3}$ was obtained as yellow powder in $78 \%$ yield.

${ }^{1} \mathrm{H}-\mathrm{NMR}\left(600 \mathrm{MHz}, \mathrm{DMSO}-d_{6}\right) \delta 10.05(\mathrm{~s}, 1 \mathrm{H}), 8.06(\mathrm{~d}, J=8.0 \mathrm{~Hz}, 2 \mathrm{H}), 8.00(\mathrm{~d}, J=7.7 \mathrm{~Hz}, 1 \mathrm{H}), 7.67$ $(\mathrm{d}, J=8.0 \mathrm{~Hz}, 2 \mathrm{H}), 7.24(\mathrm{~d}, J=8.5 \mathrm{~Hz}, 2 \mathrm{H}), 7.17(\mathrm{t}, J=7.5 \mathrm{~Hz}, 1 \mathrm{H}), 6.91-6.83(\mathrm{~m}, 4 \mathrm{H}), 6.26(\mathrm{~s}, 1 \mathrm{H})$, 3.70 (s, 3H), $3.31(\mathrm{~s}, 3 \mathrm{H}) .{ }^{13} \mathrm{C}-\mathrm{NMR}\left(151 \mathrm{MHz}, \mathrm{DMSO}-d_{6}\right) \delta 168.4,160.2,156.6,147.7,147.3,142.1$, 136.2, 131.3, 130.9, 130.8, 128.1, 124.9, 121.5, 120.5, 120.2, 116.1, 114.5, 106.9, 55.7, 43.7. HR-MS (ESI): calcd for $\mathrm{C}_{25} \mathrm{H}_{20} \mathrm{NaO}_{6} \mathrm{~S}: 471.0878\left([\mathrm{M}+\mathrm{Na}]^{+}\right)$, found: 471.0863 . 


\section{The Pictures of the Compounds in Vials and Their Fluorescent Spectra}

The left part of the picture for each compound was taken in a darkroom under a handheld UV lamp. The right part of the picture was taken under ambient light conditions as viewed with naked eyes. The solution was prepared in DMSO $(0.1 \mathrm{mM})$ and solid-state emission can vary depending on packing of residual solvent molecules. The normalized absorption and fluorescence emission spectra were also presented next to its corresponding picture of the compound in a glass vial for each compound.
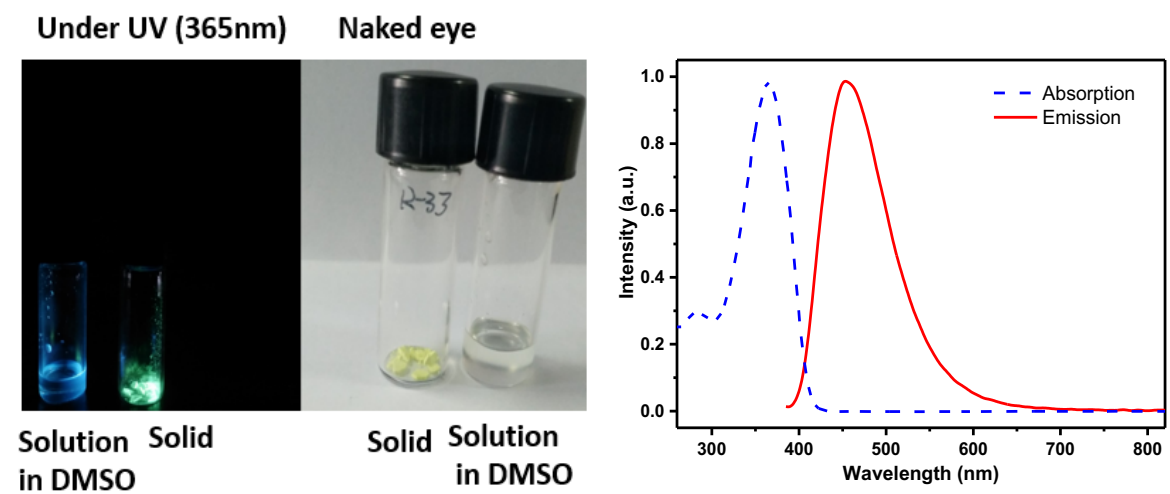

Figure S1. The picture of the compound in a glass vial and fluorescent spectra of $\mathbf{2 a 1}$
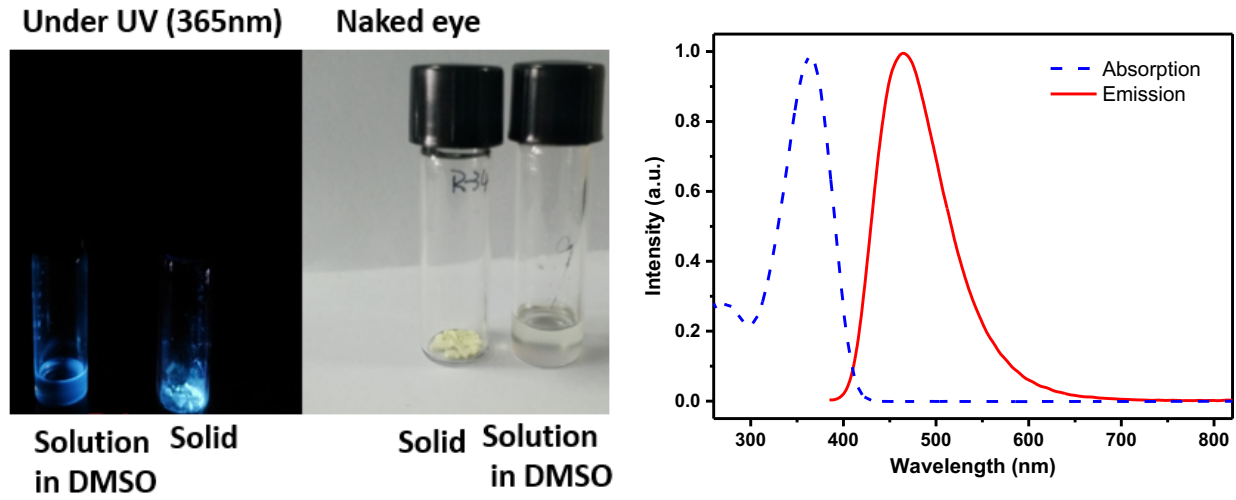

Figure S2. The picture of the compound in a glass vial and fluorescent spectra of $\mathbf{2} \mathbf{a} 2$
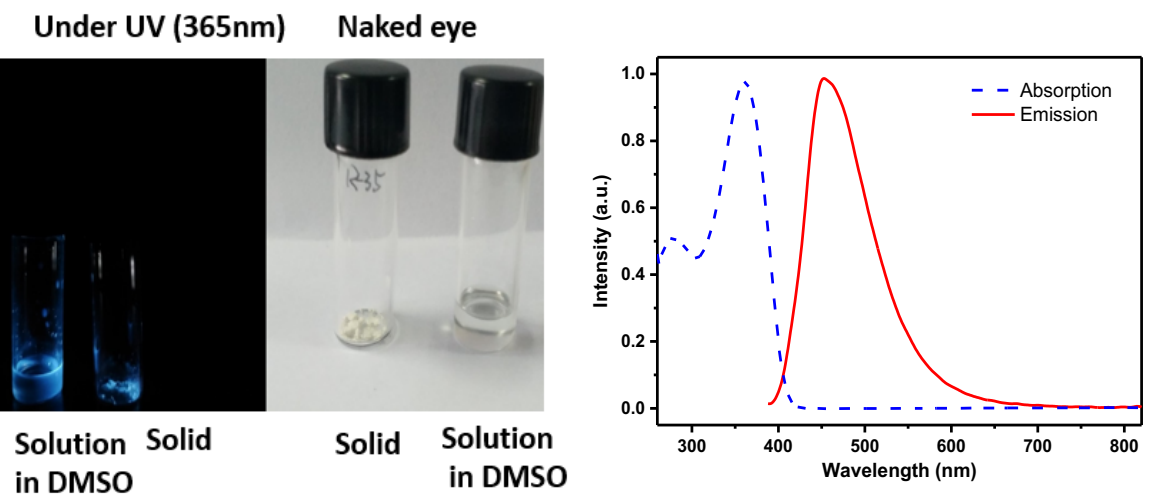

Figure S3. The picture of the compound in a glass vial and fluorescent spectra of $\mathbf{2 a 3}$ 

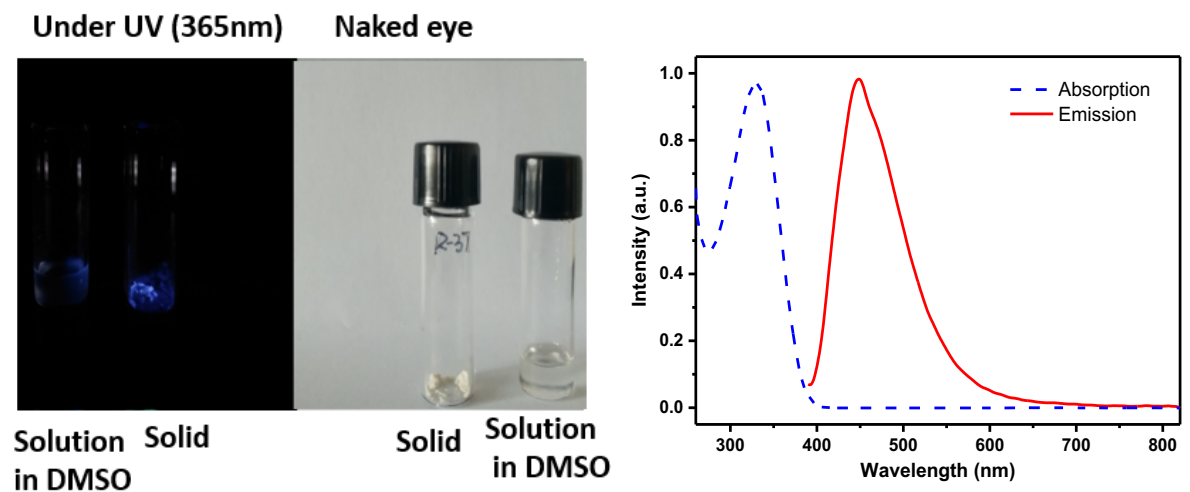

Figure S4. The picture of the compound in a glass vial and fluorescent spectra of 2a4
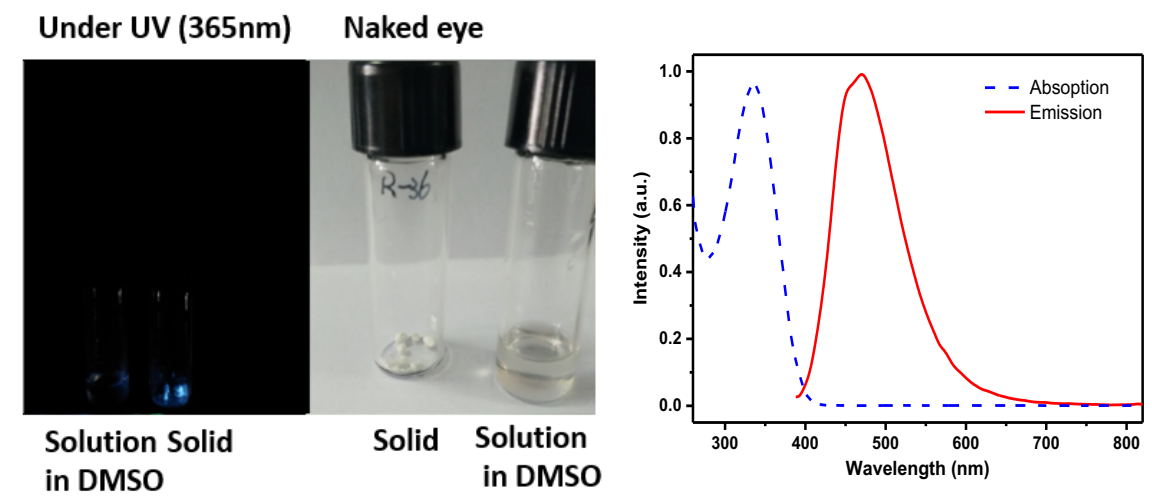

Figure S5. The picture of the compound in a glass vial and fluorescent spectra of 2a5
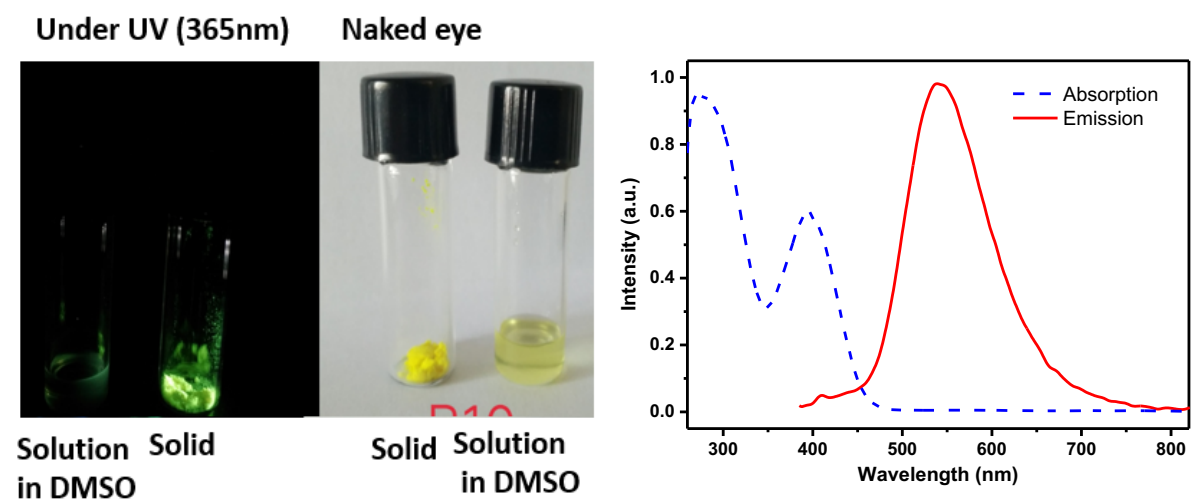

Figure S6. The picture of the compound in a glass vial and fluorescent spectra of 2 a6 

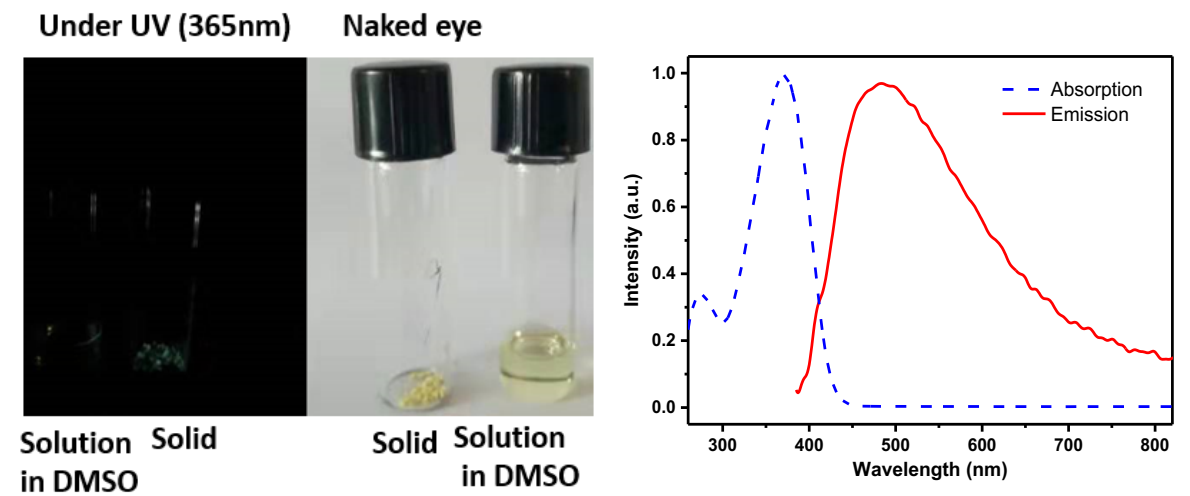

Figure S7. The picture of the compound in a glass vial and fluorescent spectra of $2 \mathrm{a} 7$
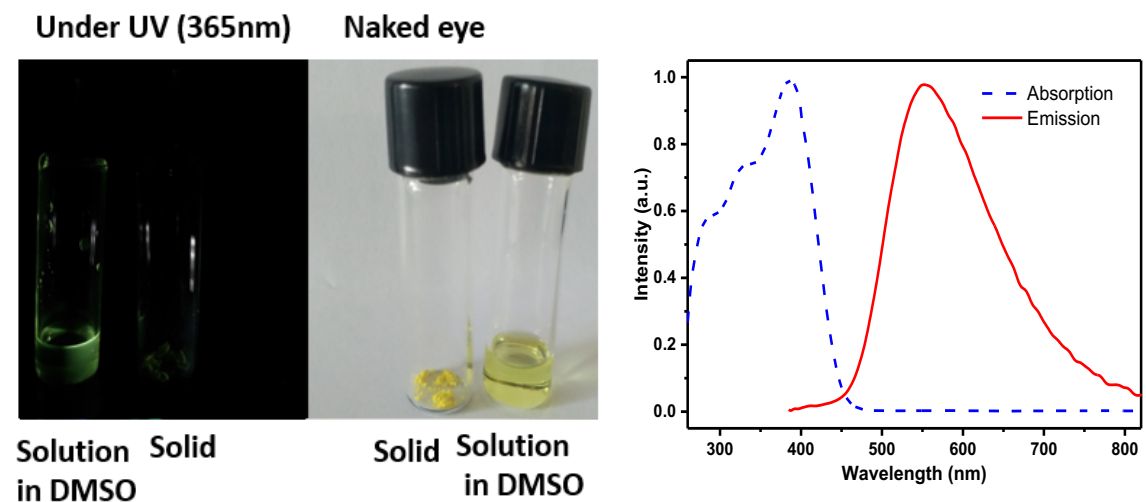

Figure S8. The picture of the compound in a glass vial and fluorescent spectra of 2a8
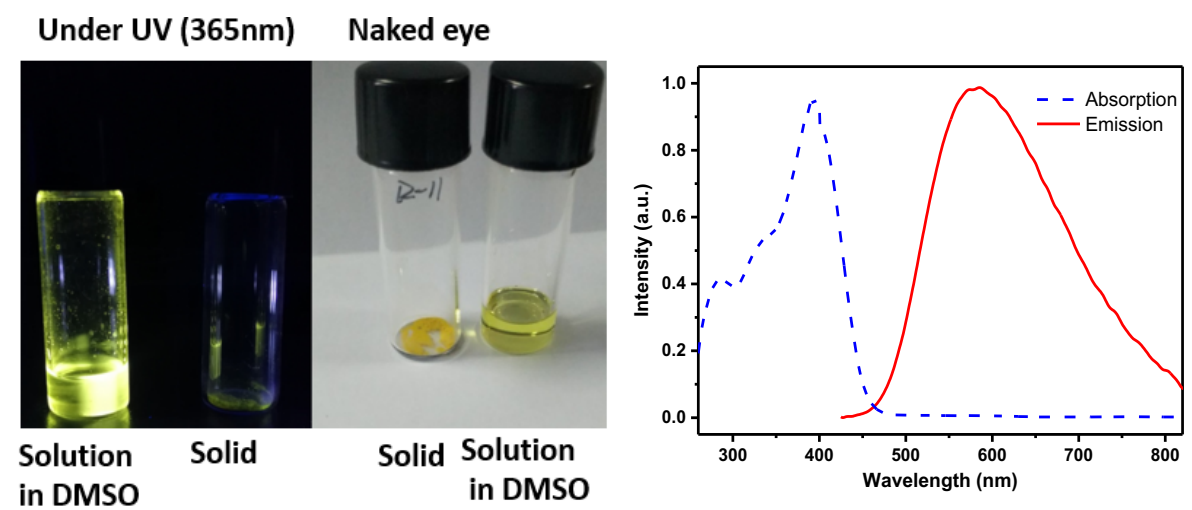

Figure S9. The picture of the compound in a glass vial and fluorescent spectra of 2a9 


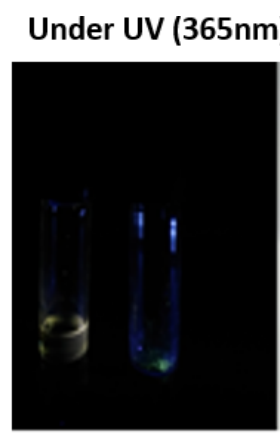

Solution Solid in DMSO
Naked eye

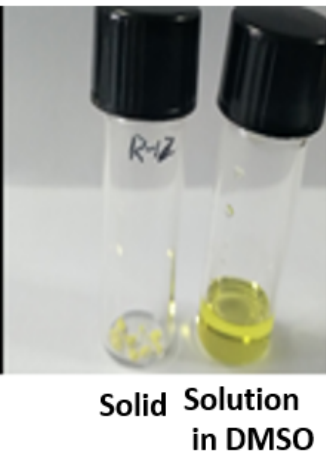

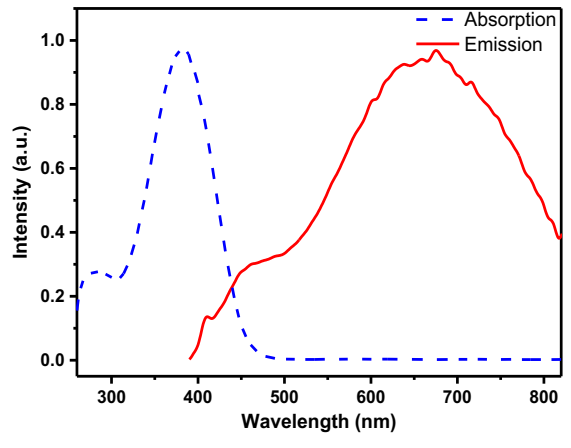

Figure S10. The picture of the compound in a glass vial and fluorescent spectra of 2a10

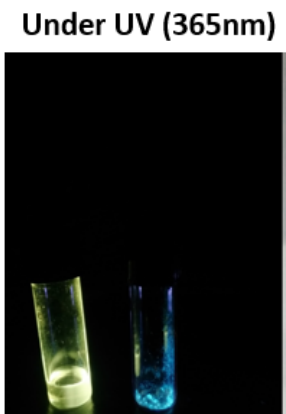

Solution Solid in DMSO

\section{Naked eye}

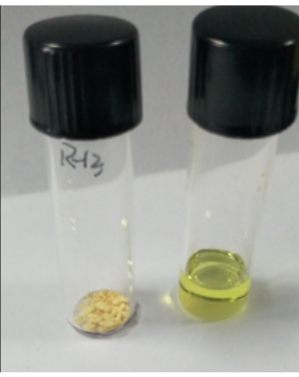

Solid Solution in DMSO

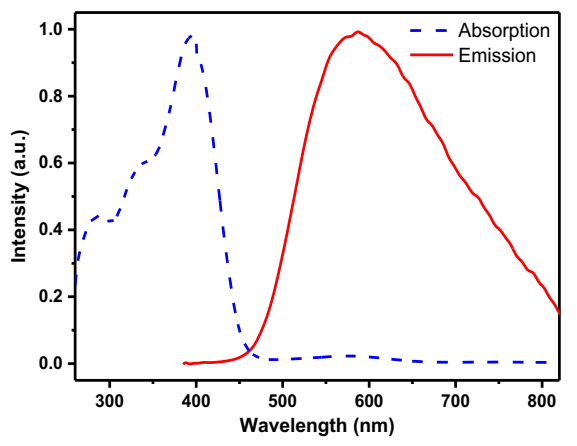

Figure S11. The picture of the compound in a glass vial and fluorescent spectra of 2a11

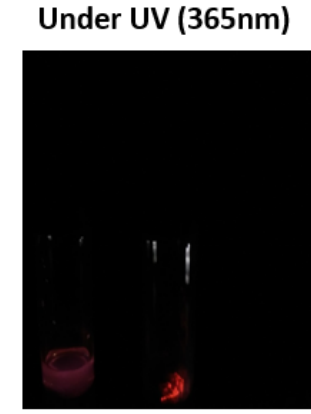

Solution Solid in DMSO
Naked eye

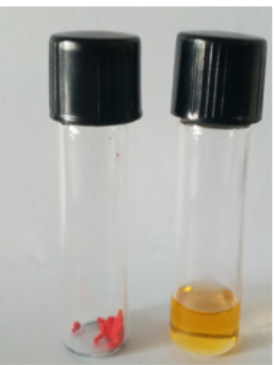

Solid Solution in DMSO

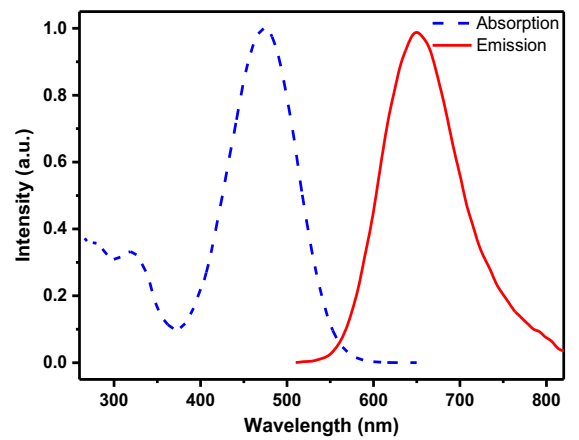

Figure S12. The picture of the compound in a glass vial and fluorescent spectra of 2 a12 


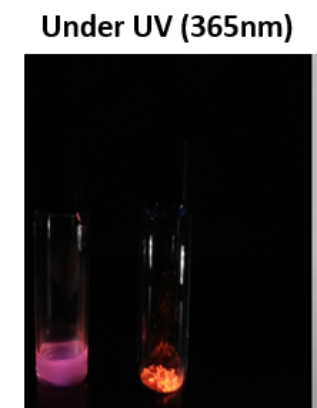

Solution Solid in DMSO
Naked eye

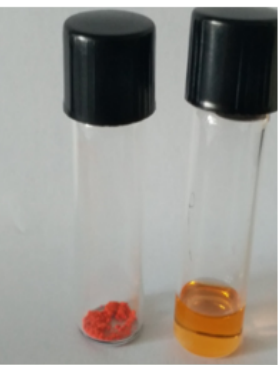

Solid Solution in DMSO

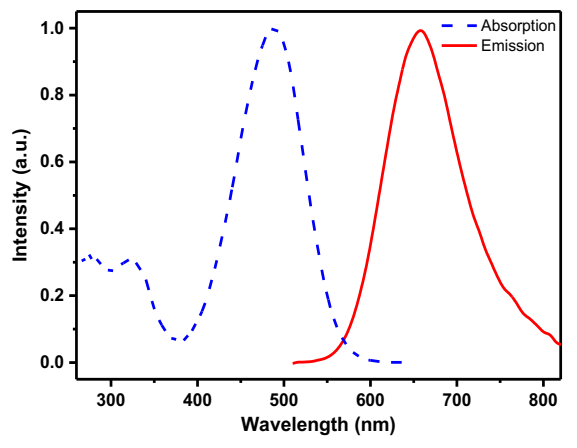

Figure S13. The picture of the compound in a glass vial and fluorescent spectra of 2a13
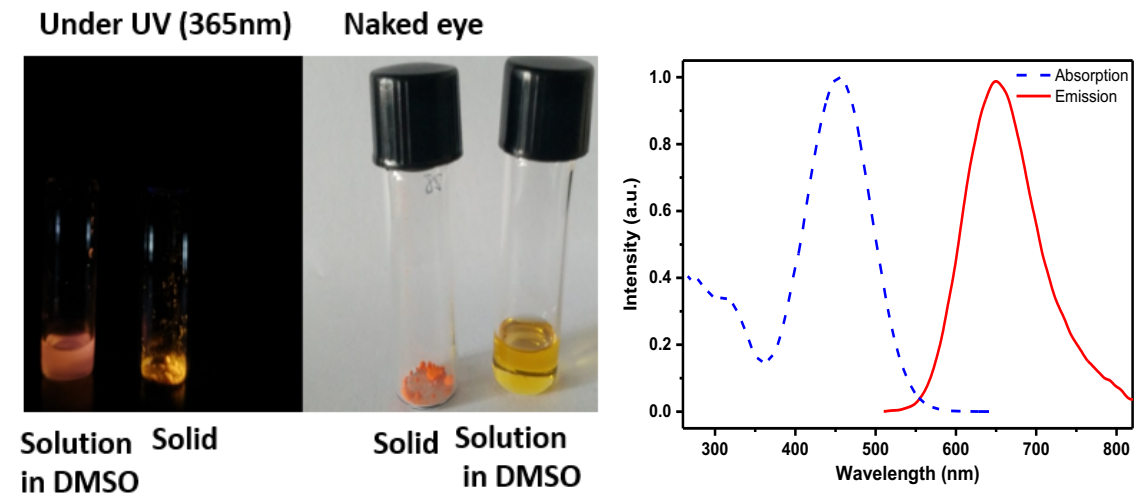

Figure S14. The picture of the compound in a glass vial and fluorescent spectra of 2a14
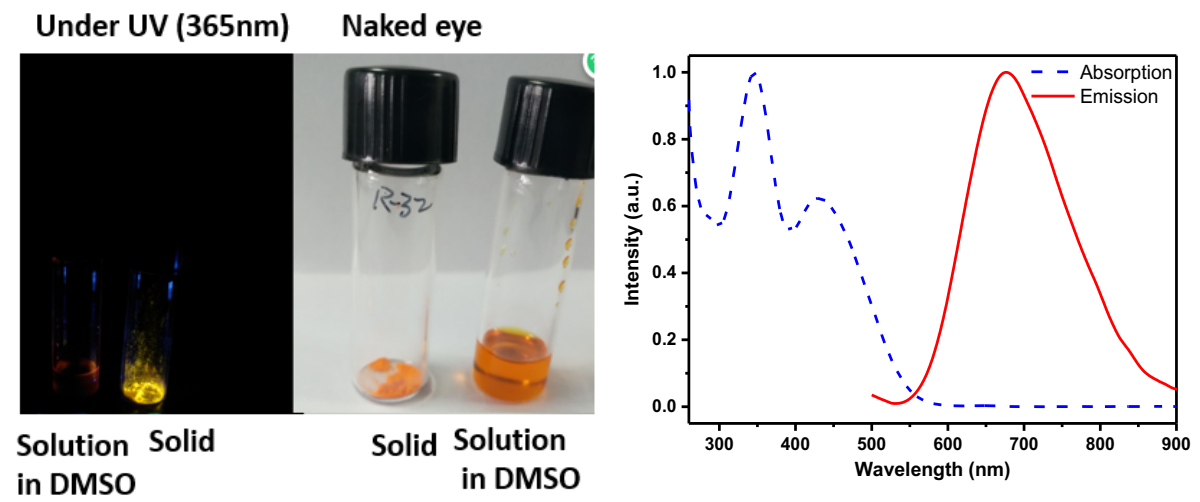

Figure S15. The picture of the compound in a glass vial and fluorescent spectra of 2 a15 


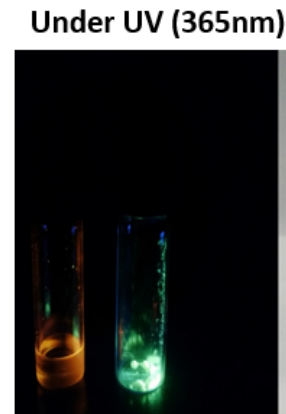

Solution Solid in DMSO
Naked eye

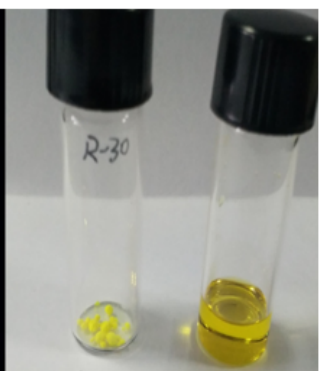

Solid Solution

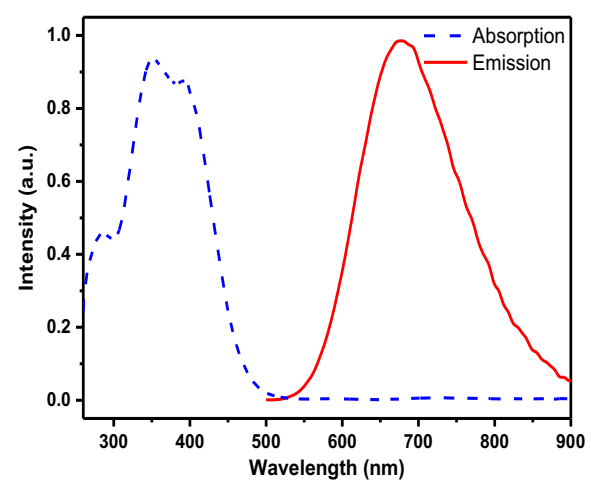

Figure S16. The picture of the compound in a glass vial and fluorescent spectra of 2 a16

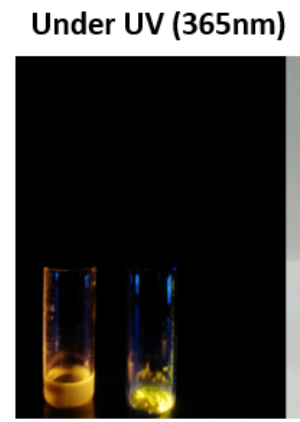

Solution Solid in DMSO

\section{Naked eye}

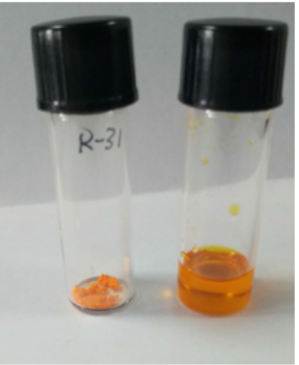

Solid Solution in DMSO

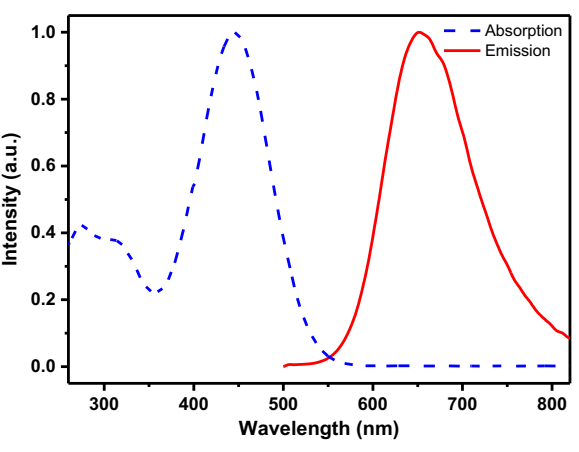

Figure S17. The picture of the compound in a glass vial and fluorescent spectra of 2a17

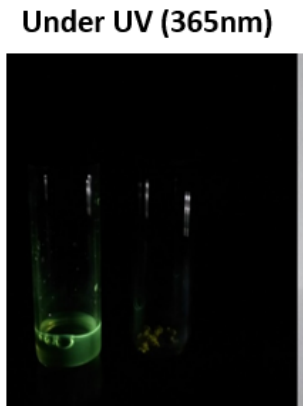

Solution Solid in DMSO

\section{Naked eye}

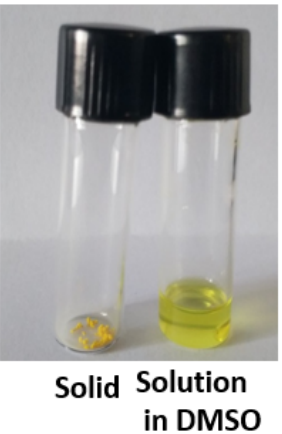

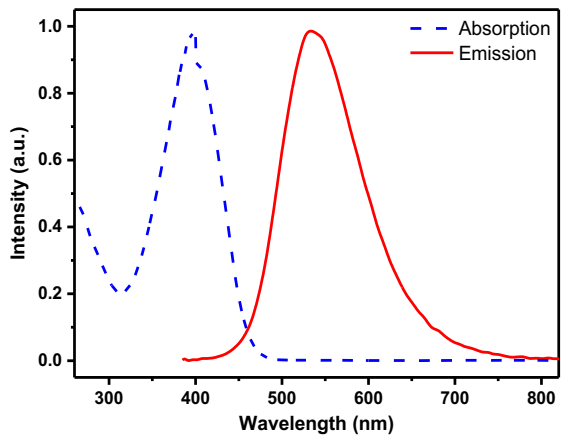

Figure S18. The picture of the compound in a glass vial and fluorescent spectra of $\mathbf{2 b 1}$ 


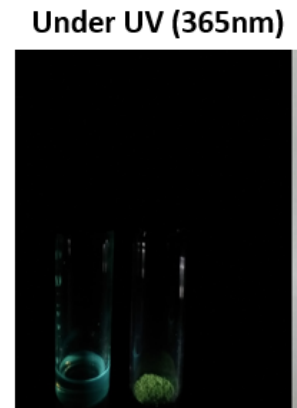

Solution Solid in DMSO

\section{Naked eye}

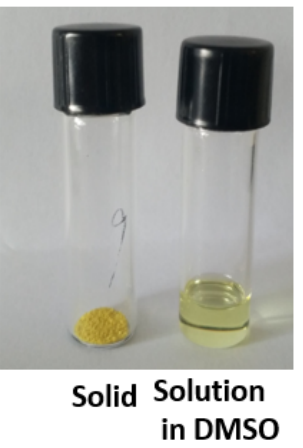

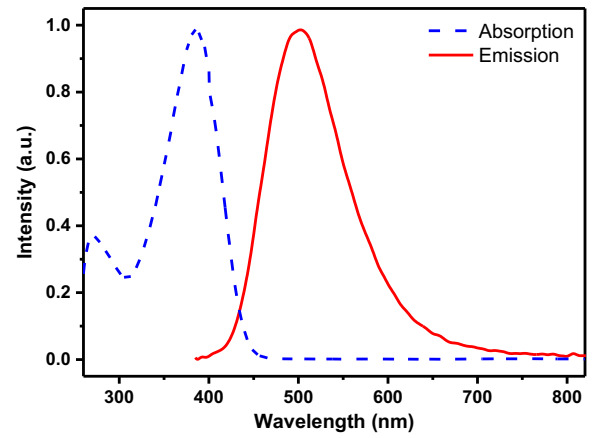

Figure S19. The picture of the compound in a glass vial and fluorescent spectra of $\mathbf{2} \mathbf{b 2}$
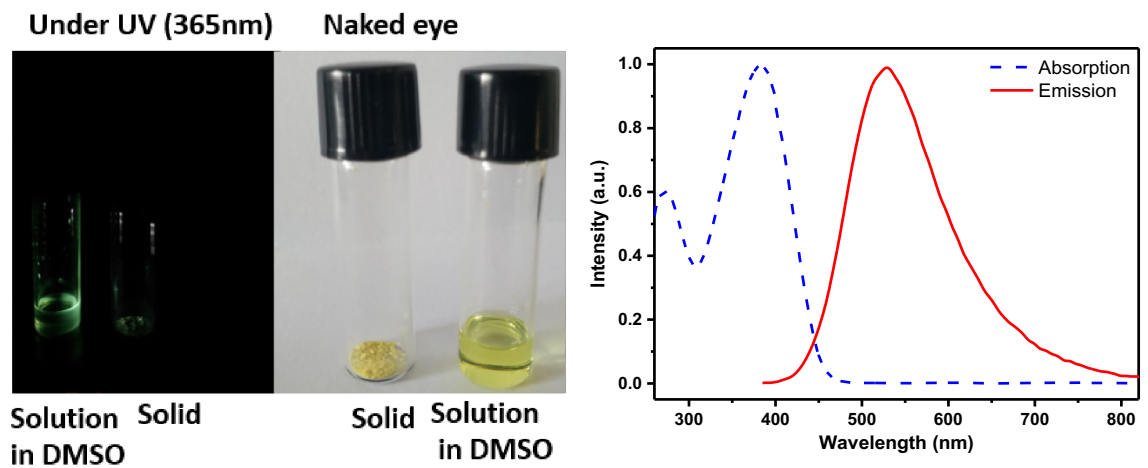

Figure S20. The picture of the compound in a glass vial and fluorescent spectra of $\mathbf{2 b 3}$

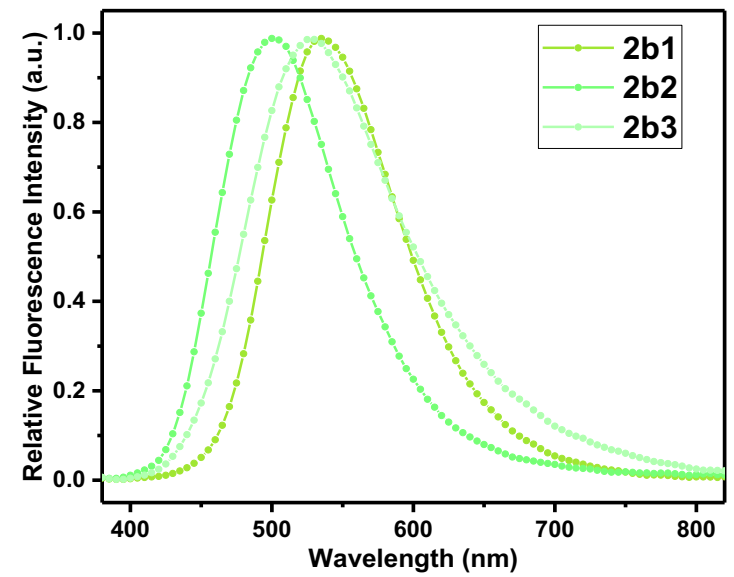

Figure S21. The emission spectra of those compounds with $\mathrm{OH}$ group located at different position on ring C. (2b1-2b3). 


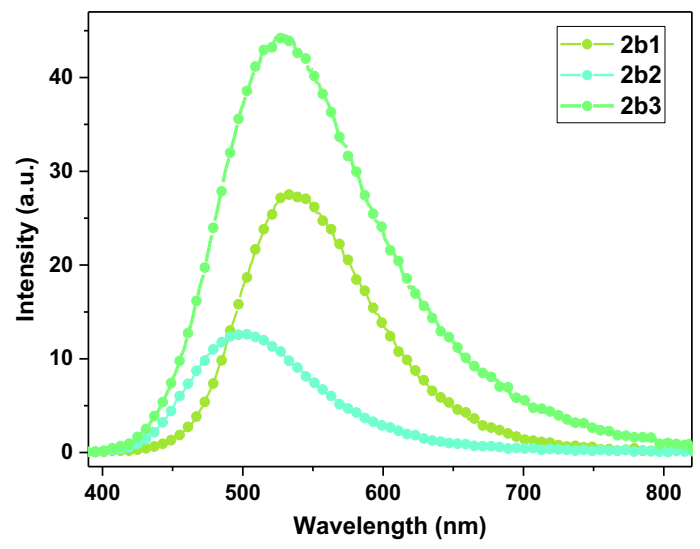

Figure S22. The fluorescent intensity of those compounds in the DMSO $(100 \mu \mathrm{M})$ with $\mathrm{OH}$ group located at different position on ring C. (2b1-2b3)

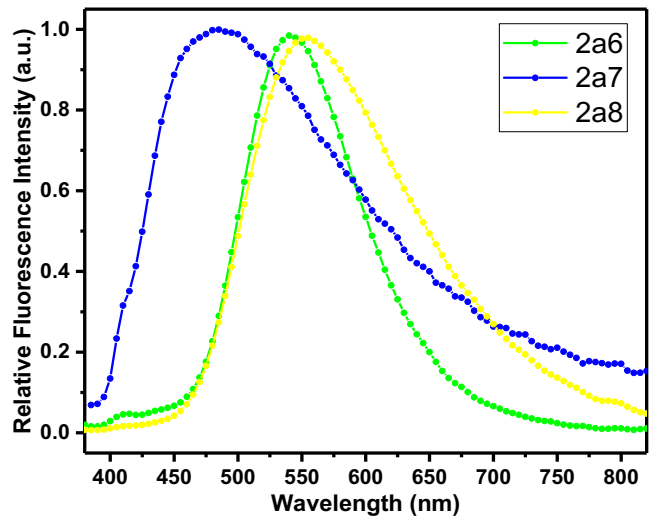

Figure S23. The emission spectra of those compounds in the DMSO $(100 \mu \mathrm{M})$ with OH group located at different position on ring C. (2a6-2a8).

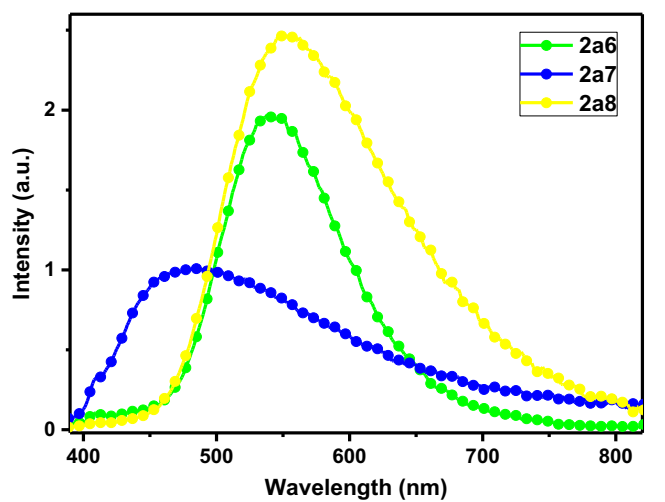

Figure S24. The fluorescent intensity of those compounds in the DMSO $(100 \mu \mathrm{M})$ with OH group located at different position on ring C. (2a6-2a8) 


\section{The Photophysical Data of the Rofecoxib Analogues}

Table S1. Photophysical data of 2a1-2a17 and 2b1-2b3.

\begin{tabular}{cccccc}
\hline Compoud & $\begin{array}{c}\lambda_{\max } \\
(\mathbf{n m})^{\mathbf{a}}\end{array}$ & $\begin{array}{c}\boldsymbol{\lambda}_{\max } \\
\mathbf{( n m})^{\mathbf{b}}\end{array}$ & $\boldsymbol{\Delta} \boldsymbol{\lambda}(\mathbf{n m})^{\mathbf{c}}$ & $\boldsymbol{\Delta v} \mathbf{( c m}^{-\mathbf{1}} \mathbf{c}^{\mathbf{c}}$ & $\boldsymbol{\Phi}_{\mathbf{f}^{\mathbf{d}}}$ \\
\hline $\mathbf{2 a 1}$ & 365 & 455 & 90 & 5419 & 0.38 \\
$\mathbf{2 a 2}$ & 364 & 462 & 98 & 5828 & 0.26 \\
$\mathbf{2 a 3}$ & 361 & 453 & 92 & 5626 & 0.06 \\
$\mathbf{2 a 4}$ & 329 & 449 & 120 & 8123 & 0.03 \\
$\mathbf{2 a 5}$ & 335 & 471 & 136 & 8619 & 0.04 \\
$\mathbf{2 a 6}$ & 394 & 541 & 148 & 6896 & 0.23 \\
$\mathbf{2 a 7}$ & 372 & 483 & 111 & 6178 & 0.02 \\
$\mathbf{2 a 8}$ & 387 & 556 & 169 & 7854 & 0.01 \\
$\mathbf{2 a 9}$ & 394 & 580 & 186 & 8139 & $<0.01$ \\
$\mathbf{2 a 1 0}$ & 382 & 664 & 282 & 11118 & 0.01 \\
$\mathbf{2 a 1 1}$ & 394 & 587 & 193 & 8345 & 0.03 \\
$\mathbf{2 a 1 2}$ & 474 & 661 & 187 & 5968 & 0.11 \\
$\mathbf{2 a 1 3}$ & 487 & 656 & 169 & 5290 & 0.18 \\
$\mathbf{2 a 1 4}$ & 454 & 649 & 195 & 6618 & 0.18 \\
$\mathbf{2 a 1 5}$ & 432 & 680 & 248 & 8442 & 0.25 \\
$\mathbf{2 a 1 6}$ & 391 & 677 & 286 & 10804 & 0.94 \\
$\mathbf{2 a 1 7}$ & 446 & 652 & 206 & 7084 & 0.40 \\
$\mathbf{2 b 1}$ & 398 & 537 & 139 & 6504 & $<0.01$ \\
$\mathbf{2 b 2}$ & 386 & 500 & 114 & 5907 & 0.03 \\
$\mathbf{2 b 3}$ & 385 & 530 & 145 & 7106 & 0.02 \\
\hline
\end{tabular}

${ }^{a}$ The maximal absorption of the rofecoxib analogues. ${ }^{b}$ The maximal emission of the rofecoxib analogues. ${ }^{\mathrm{c}}$ Stokes shift with two units. ${ }^{\mathrm{d}} \Phi_{\mathrm{f}}$ is the solid absolute fluorescence quantum yield measured by FLS980 spectrometer (Edinburgh). 


\section{Cell Viability Assay}

Method: Approximately $5 \times 10^{3}$ cells were seeded on 96 -well clear bottom plate and incubated for one day. After incubation, the cells were treated with probes $(\mathbf{2 a 1 2}, \mathbf{2 a 1 3}, \mathbf{2 a 1 6})$ for $24 \mathrm{~h}$. To analyze cell viability of the probe on cells, we performed cell viability assay using Cell proliferation kit I by following the manufacturer's instructions. The absorbance level was analyzed at $490 \mathrm{~nm}$. The treated wells relative to that in the control wells and the culture medium was used as a control.

Results: Raw264.7 and HeLa cells treated with compounds at various concentrations showed very low cytotoxicity (concentration under $12 \mu \mathrm{M}$ ).

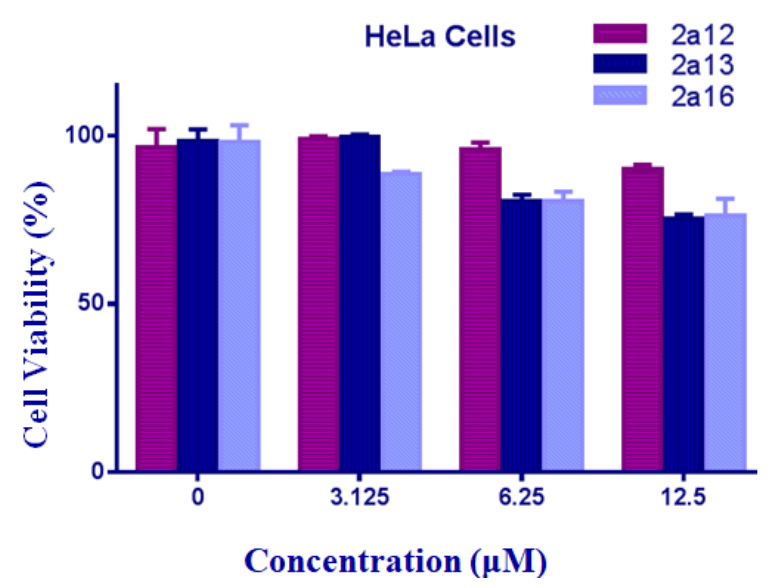

Figure S25. Cell viability values (\%) estimated by MTT assays using HeLa cells, cultured in the presence of 3.125-12.5 $\mu \mathrm{M}$ of 2a12, $2 \mathbf{a 1 3}$ and 2a16 for $24 \mathrm{~h}$ at $37^{\circ} \mathrm{C}$.

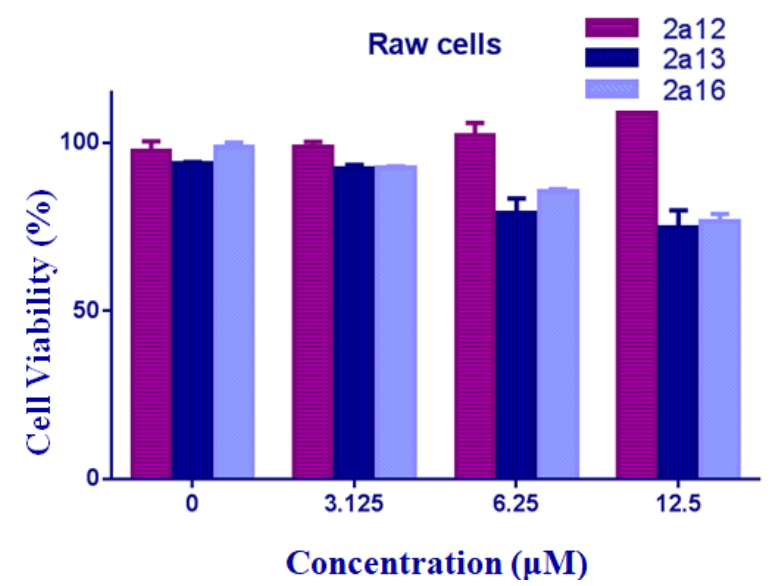

Figure S26. Cell viability values (\%) estimated by MTT assays using Raw264.7 cells. cultured in the presence of 3.125-12.5 $\mu \mathrm{M}$ of 2a12, $2 \mathrm{a} 13$ and $\mathbf{2 a 1 6}$ for $24 \mathrm{~h}$ at $37^{\circ} \mathrm{C}$.

\section{Western Blotting Analysis for Raw264.7 and HeLa Cells COX-2 Protein Expression}

Raw264.7 and HeLa cells were collected to extract protein. The protein concentration was determined by Bio spectrometer (Eppendorf). Protein samples were separated by SDS-PAGE and electro-transferred 
onto nitrocellulose blotting membrane (GE Healthcare). The membrane was incubated overnight at $4{ }^{\circ} \mathrm{C}$ with 1:1000 COX-2 antibody (Cell Signaling) and Actin (Invitrogen) separately. The goat anti-rabbit secondary antibody was used to blot target proteins. Signals were detected by chemiluminescence ECL detection (Advansta) and ChemiDoc imaging system (Bio-RAD).

Method: After the cell was stabilized for one day, the cell was collected to test COX-2 expression at the protein level.

Results: The COX-2 expression level in HeLa cells was higher than that in Raw264.7 cells. The western blotting analysis also confirmed that the COX-2 levels are down-regulated in the presence of the celecoxib.

\section{COX-2 Inhibition Assay}

Method: Recombinant human COX-2 (1.25 unit) was incubated with $1 \mu \mathrm{M}$ hematin, $5 \mathrm{mM}$ L-glutatione, $5 \mathrm{mM}$ dopamine haydrochloride, $5 \mathrm{mM}$ EDTA and different concentrations of inhibitors or vector (DMSO) in $150 \mu \mathrm{L}$ potassium phosphate buffer $(\mathrm{pH} 8.0)$ at $37{ }^{\circ} \mathrm{C}$ for 15 minutes. Then $50 \mu \mathrm{L}$ AA was introduced into the samples at $10 \mu \mathrm{M}$ to start the reaction. After incubated 10 minutes, the samples were put on the ice and stopped by adding $50 \mu \mathrm{L}$ stop solution, which contains $1 \%$ formic acid and $100 \mathrm{ng} / \mathrm{mL}$ PGE2- $d 4$ (internal standard). Before using UPLC-MS/MS to measure the PGE2, the $\mathrm{pH}$ of samples was adjusted by $0.5 \mathrm{M} \mathrm{NaOH}$ solution to around 8 .

\section{Incubation Study of $2 \mathrm{a} 16$ and COX-2}

Method: Prepared $1 \mu \mathrm{M}$ fluorescent probe $\mathbf{2 a 1 6}$ solution in PBS ( $\mathrm{pH}=7.4$ ) containing 10\% DMSO with or without COX-2 enzyme (4Kunit/mL). The PBS containing $10 \%$ DMSO with or without COX-2 enzyme were used as negative control. The emission spectra were obtained using Cytation 5 imaging reader (BioTek) with a fixed excitation wavelength at $480 \mathrm{~nm}$. The single point fluorescent intensity were area scanning of fluorescent intensity are both detected by Cytation 5 with fluorescence excitation at 480 $\mathrm{nm}$, emission at $590 \mathrm{~nm}$.

\section{Cell Culture and Fluorescence Imaging}

Cell Culture: Human cervical cancer (HeLa), mouse monocyte/macrophage (Raw264.7) cell lines were obtained from American type culture collection. All cells were cultured in Dulbecco's modified Eagle's 
media (Hyclone) supplemented with 10\% fetal bovine serum (Cell Signaling Technology) and $1 \%$ penicillin-streptomycin (Hyclone). Cultures were incubated at $37^{\circ} \mathrm{C} / 5 \% \mathrm{CO}_{2}$.

Fluorescence Imaging: We assessed the COX-2-targeting ability of 2a16 in different cell lines. 2 a16 was incubated with two different live cell lines-Raw264.7 and carcinoma cell lines HeLa for $2 \mathrm{~h}$, and them washed with PBS buffer 3 times. Subsequently, the fluorescence picture of the compound in a glass vials were taken. In order to confirm that $\mathbf{2 a 1 6}$ could specifically target COX-2, the expression of COX2 was blocked by treatment with celecoxib, which specifically inhibits the expression of COX-2. After treatment of the HeLa cells with celecoxib $(0$ and $100 \mu \mathrm{M})$ for $12 \mathrm{~h}$, Western blotting showed that the expression of COX-2 in the cells was markedly reduced. After $12 \mathrm{~h}$ of celecoxib treatment, the HeLa cells were incubated for another $2 \mathrm{~h}$ with $\mathbf{2 a 1 6}(2 \mu \mathrm{M})$. Cell imaging showed that the fluorescence intensity of the HeLa cells decreased significantly. Taken together, the evidence shows that the luminescence of $2 \mathbf{a 1 6}$ is linked to COX-2 expression, suggesting, in turn, that $\mathbf{2 a 1 6}$ could specifically recognize COX-2 in human cancer cells.

Results: We then observed bright red fluorescence of $\mathbf{2 a 1 6}$ in carcinoma HeLa cell lines, which have COX-2 over-expression, we could rarely observe any fluorescence in the Raw264.7, where the COX-2 expression is lower. Cell imaging showed that the fluorescence intensity of the HeLa cells decreased significantly after treatment with celecoxib for $12 \mathrm{~h}$, down-regulating the COX-2 expression level, the evidence shows that the luminescence of $\mathbf{2 a 1 6}$ is linked to COX-2 expression, suggesting, in turn, that 2a16 could specifically recognize COX-2 in human cancer cells.

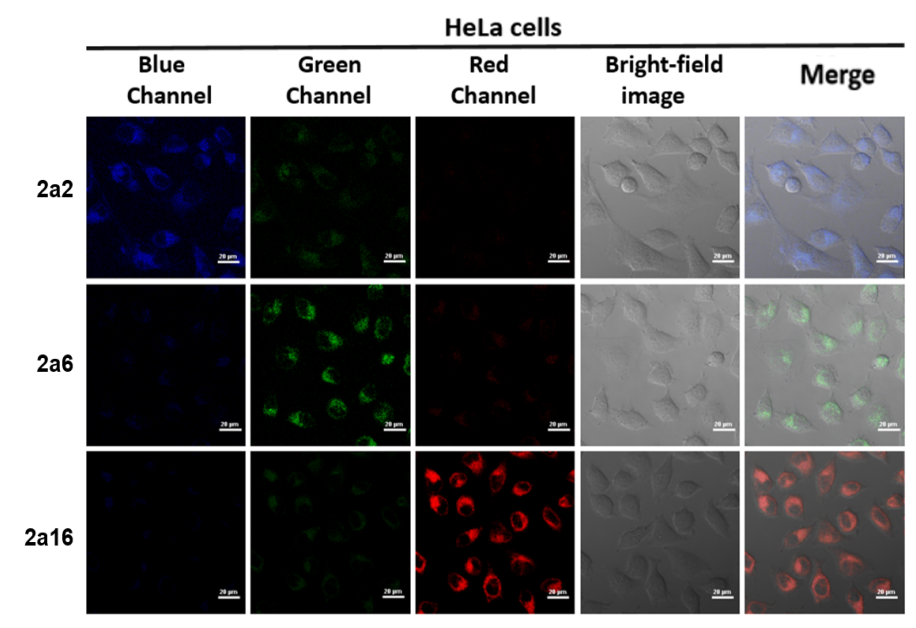

Figure S27. Imaging ability of rofecoxib analogues. HeLa cells were treated with 2a2, 2a6 and 2a16 (5 $\mu \mathrm{M})$ for 2 h. (Magnification: $\times$ 40; $\lambda$ ex: $405 \mathrm{~nm}$; Green, $\lambda \mathrm{em}$ : 500-550 nm; Red, $\lambda \mathrm{em}$ : 570-1000 nm. 


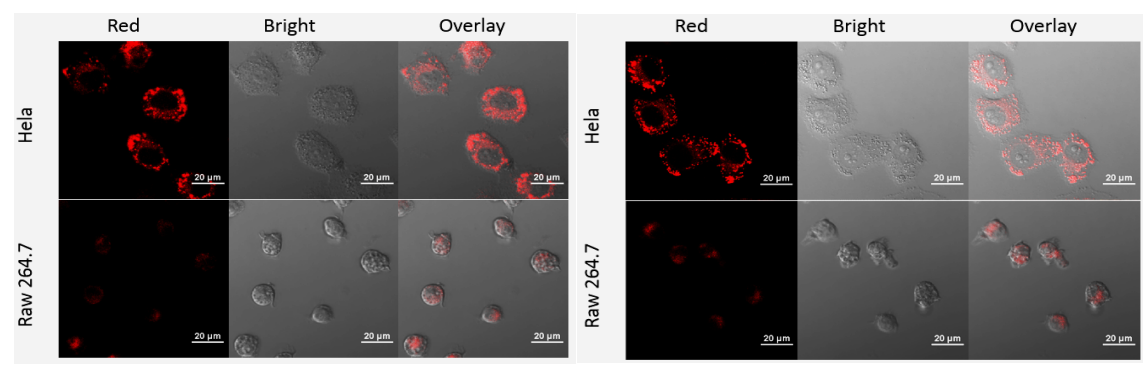

Figure S28. Confocal microscopy picture of the compound in a glass vials of Raw264.7 and HeLa cell lines. All cells were treated with $2 \mathrm{a16}(2 \mu \mathrm{M})$ for $2 \mathrm{~h}$ and washed with PBS buffer three times.

(Raw264.7, HeLa cells) (Magnification: $\times$ 40; $\lambda$ ex: 405 nm; Green, $\lambda$ em: 500-550 nm; Red, $\lambda$ em: 570$1000 \mathrm{~nm}$.

\section{Human Esophageal Tissue Fluorescence Imaging}

Human ESCC and adjacent tissues were collected and fixed in $10 \%$ formalin overnight at $4{ }^{\circ} \mathrm{C}$. All tissues were processed for embedding in paraffin following standard methods, and then the tissues sections were mounted on glass slides. For fluorescence imaging, sections were incubated with $10 \mu \mathrm{M} 2 \mathrm{a} 16$ for $0.5 \mathrm{~h}$, and then washed by PBS for 3 times at room temperature. After stained by DAPI and treated by antifade reagent, picture of the compound in a glass vials were collected on a confocal laser scanning microscope.

\section{Statistics and Reproducibility}

Student's t-test was used for comparisons of two groups $(\mathrm{n} \geq 3)$. P values less than 0.05 were considered significant. Error bars indicate the standard deviation (s.d.). All experiments were performed three or more times independently under identical or similar conditions.

\section{Crystal Data of 2 a16}

The crystal structure of $\mathbf{2 a 1 6}$ has been deposited into The Cambridge Crystallographic Data Centre (CCDC) with the CCDC deposit number as 2063013. The following is the detailed crystallographic information:

Number Label Charge SybylType "Xfrac + ESD" "Yfrac + ESD" "Zfrac + ESD" "Symm. op." $1 \mathrm{~S} 10$ S.o2 0.41057(2) 0.82539(10) 0.44231(3) x,y,z

$2 \mathrm{O} 00.20 .42102(8) 1.0501(3) 0.44506(10) \mathrm{x}, \mathrm{y}, \mathrm{z}$

3 O2 $00.20 .40987(7) 0.7204(3) 0.51016(8) x, y, z$ 
4 O3 0 O.2 0.01699(6) 0.7456(2) 0.03947(8) x,y,z $5 \mathrm{O} 400.30 .10142(5)$ 0.53019(18) 0.06229(6) x,y,z 6 O5 $00.30 .44613(6) 0.3120(2) 0.19511(9) \mathrm{x}, \mathrm{y}, \mathrm{z}$ 7 N1 0 N.3 0.31765(6) 0.1760(2) 0.12560(8) x,y,z 8 C1 0 C.3 0.46727(9) 0.7006(5) 0.41140(13) x,y,z 9 H1A 0 H 0.5088840 .7164220 .450257 x,y,z 10 H1B 0 H 0.4669530 .7638720 .363879 x,y,z 11 H1C 0 H 0.4571240 .5530550 .403077 x,y,z 12 C2 0 C.3 0.33700(7) 0.7766(3) 0.36689(9) x,y,z 13 C3 0 C.2 0.30970(8) 0.9366(3) 0.31560(10) x,y,z 14 H3 0 H 0.3290441 .0688090 .321746 x,y,z 15 C4 0 C.2 0.25353(8) 0.8999(3) 0.25506(10) x,y,z 16 H4 0 H 0.2352231 .0077420 .219982 x,y,z 17 C5 0 C.2 0.22410(7) 0.7049(2) 0.24586(9) x,y,z 18 C6 0 C.2 0.25092(8) 0.5456(3) 0.29926(9) x,y,z 19 H6 0 H 0.2306560 .4151460 .294337 x,y,z 20 C7 0 C.2 0.30787(8) 0.5808(3) 0.35988(10) x,y,z 21 H7 0 H 0.3262750 .4740980 .395414 x,y,z 22 C8 0 C.2 0.16535(7) 0.6705(2) 0.17823(9) x,y,z 23 C9 0 C.2 0.11060(7) 0.7852(3) 0.15591(9) x,y,z 24 C10 0 C.2 0.09172(7) 0.9621(3) 0.19444(10) x,y,z 25 C11 0 C.2 0.11161(9) 0.9719(3) 0.27455(12) x,y,z 26 H11 0 H $0.1363240 .8631130 .304111 x, y, z$ 27 C12 0 C.2 0.09521(11) 1.1409(4) 0.31091(14) x,y,z 28 H12 0 H 0.1092851 .1468020 .364728 x,y,z 29 C13 0 C.2 0.05787(11) 1.3015(4) 0.26737(17) x,y,z 30 H13 0 H 0.0468461 .4159860 .291822 x,y,z 31 C14 0 C.2 0.03705(10) 1.2924(3) 0.18820(15) x,y,z 32 H14 0 H 0.0117111 .4007120 .159093 x,y,z 33 C15 0 C.2 0.05325(8) 1.1243(3) 0.15117(12) x,y,z 
34 H15 0 H 0.0385531 .1189120 .097333 x,y,z

35 C16 0 C.2 0.06934(7) 0.6974(3) 0.08128(10) x,y,z

36 C17 0 C.2 0.16032(7) 0.5105(3) 0.12031(9) x,y,z

37 C18 0 C.2 0.20438(7) 0.3689(3) 0.11911(9) x,y,z

38 H18 0 H 0.2433430 .3824960 .159435 x,y,z

39 C19 0 C.2 0.20187(7) 0.1974(3) 0.06564(9) x,y,z

40 C20 0 C.2 0.14470(8) 0.1187(3) 0.01298(10) x,y,z

41 H20 0 H 0.1065490 .1885940 .006550 x,y,z

42 C21 0 C.2 0.14415(9) -0.0608(3) -0.02946(11) x,y,z

43 H21 0 H $0.105726-0.112648-0.063766$ x,y,z

44 C22 0 C.2 0.20056(10) -0.1637(3) -0.02113(12) x,y,z

45 H22 0 H $0.199941-0.286718-0.049035$ x,y,z

46 C23 0 C.2 0.25779(9) -0.0855(3) 0.02822(11) x,y,z

47 H23 0 H $0.295646-0.1539720 .032177$ x,y,z

48 C24 0 C.2 0.25973(7) 0.0940(3) 0.07206(9) x,y,z

49 C25 0 C.3 0.34142(9) 0.3653(3) 0.09848(12) x,y,z

50 H25A 0 H 0.3072840 .4682600 .079665 x,y,z

51 H25B 0 H 0.3556330 .3282470 .056008 x,y,z

52 C26 0 C.3 0.39590(9) 0.4593(3) 0.16349(13) x,y,z

53 H26A 0 H 0.4121610 .5815140 .144499 x,y,z

54 H26B 0 H 0.3805290 .5067100 .203921 x,y,z

55 C27 0 C.3 0.42290(9) 0.1290(3) 0.22109(12) x,y,z

56 H27A 0 H 0.4072490 .1678050 .262206 x,y,z

57 H27B 0 H 0.4576090 .0290720 .242121 x,y,z

58 C28 0 C.3 0.37012(8) 0.0261(3) 0.15650(12) x,y,z

59 H28A 0 H $0.385782-0.0172610 .115851$ x,y,z

60 H28B 0 H $0.355205-0.0987360 .175681$ x,y,z

Number Atom1 Atom2 Type Polymeric Cyclicity Length SybylType

$1 \mathrm{~S} 1 \mathrm{O} 1$ Unknown no acyclic 1.438(2) un

2 S1 O2 Unknown no acyclic 1.420(2) un 
3 S1 C1 Unknown no acyclic 1.748(3) 1

4 S1 C2 Unknown no acyclic 1.770(1) 1

5 O3 C16 Unknown no acyclic 1.193(2) 2

6 O4 C16 Unknown no cyclic 1.389(2) 1

7 O4 C17 Unknown no cyclic 1.381(2) 1

8 O5 C26 Unknown no cyclic 1.418(2) 1

9 O5 C27 Unknown no cyclic 1.418(3) 1

10 N1 C24 Unknown no acyclic 1.423(2) 1

11 N1 C25 Unknown no cyclic 1.466(3) 1

12 N1 C28 Unknown no cyclic 1.460(2) 1

13 C1 H1A Unknown no acyclic 0.9601

14 C1 H1B Unknown no acyclic 0.9601

15 C1 H1C Unknown no acyclic 0.9601

16 C2 C3 Unknown no cyclic 1.373(2) 1

17 C2 C7 Unknown no cyclic 1.384(3) 1

18 C3 H3 Unknown no acyclic 0.9301

19 C3 C4 Unknown no cyclic 1.376(2) un

20 C4 H4 Unknown no acyclic 0.9301

21 C4 C5 Unknown no cyclic 1.380(2) un

22 C5 C6 Unknown no cyclic 1.389(2) un

23 C5 C8 Unknown no acyclic 1.476(2) un

24 C6 H6 Unknown no acyclic 0.9301

25 C6 C7 Unknown no cyclic 1.387(2) un

26 C7 H7 Unknown no acyclic 0.9301

27 C8 C9 Unknown no cyclic 1.356(2) un

28 C8 C17 Unknown no cyclic 1.446(2) un

29 C9 C10 Unknown no acyclic 1.464(3) un 30 C9 C16 Unknown no cyclic 1.470(2) un

31 C10 C11 Unknown no cyclic 1.386(3) un

32 C10 C15 Unknown no cyclic 1.396(2) un 
33 C11 H11 Unknown no acyclic 0.9301

34 C11 C12 Unknown no cyclic 1.377(3) un

35 C12 H12 Unknown no acyclic 0.9301

36 C12 C13 Unknown no cyclic 1.380(3) un

37 C13 H13 Unknown no acyclic 0.9301

38 C13 C14 Unknown no cyclic 1.368(4) un

39 C14 H14 Unknown no acyclic 0.9301

40 C14 C15 Unknown no cyclic 1.378(3) un

41 C15 H15 Unknown no acyclic 0.9301

42 C17 C18 Unknown no acyclic 1.336(3) un

43 C18 H18 Unknown no acyclic 0.9301

44 C18 C19 Unknown no acyclic 1.453(3) un

45 C19 C20 Unknown no cyclic 1.398(2) un

46 C19 C24 Unknown no cyclic 1.416(2) un

47 C20 H20 Unknown no acyclic 0.9301

48 C20 C21 Unknown no cyclic 1.376(3) un

49 C21 H21 Unknown no acyclic 0.9301

50 C21 C22 Unknown no cyclic 1.378(3) un

$51 \mathrm{C} 22 \mathrm{H} 22$ Unknown no acyclic 0.9301

52 C22 C23 Unknown no cyclic 1.376(3) un

$53 \mathrm{C} 23 \mathrm{H} 23$ Unknown no acyclic 0.9301

54 C23 C24 Unknown no cyclic 1.385(3) un

55 C25 H25A Unknown no acyclic 0.9701

56 C25 H25B Unknown no acyclic 0.9701

57 C25 C26 Unknown no cyclic 1.500(2) 1

58 C26 H26A Unknown no acyclic 0.9701

59 C26 H26B Unknown no acyclic 0.9701

60 C27 H27A Unknown no acyclic 0.9701

61 C27 H27B Unknown no acyclic 0.9701

62 C27 C28 Unknown no cyclic 1.500(2) 1 
63 C28 H28A Unknown no acyclic 0.9701

64 C28 H28B Unknown no acyclic 0.9701

\section{Crystal Structure Analysis of 2a16}

For its mechanochromism, it was hypothesized that the two-color mechanochromic luminescence

(MCL) of $2 \mathbf{a 1 6}$ was ascribed to the force-induced transformation of the molecular packing. Therefore, it was of great significance to study the mechanism on MCL of $2 \mathbf{a 1 6}$ by analyzing the single crystal of the compound. To our delight, a single crystal of $\mathbf{2 a 1 6}$ was obtained and analyzed by X-ray diffraction. Compound 2a16 packed in the monoclinic crystal system, from which two representative tetramers were extracted to illustrate its intermolecular packing. As shown in Figure S29A, the phenyl group (ring A) and 4-(methylsulfonyl)phenyl group (ring B) adopted a twisted conformation to connect to the lactone ring, with their dihedral angles as $33.91^{\circ}$ and $57.26^{\circ}$, respectively. The other phenyl group (ring C) adopted a less twisted conformation to connect to the double bond with the dihedral angle as $19.58^{\circ}$. The dihedral angles among the phenyl rings were calculated to be $59.46^{\circ}, 53.21^{\circ}$, and $57.86^{\circ}$. It is interesting to note that two $\mathrm{C}-\mathrm{H} \cdots \mathrm{O}$ interactions existed between the oxygen atom of the morpholine ring and the $\mathrm{C}-\mathrm{H}$ of methylsulfonyl group and also another $\mathrm{C}-\mathrm{H}$ of the morpholine ring (2.472 and $2.552 \AA$, respectively) (Figure S29B). In addition, one C-H $\cdots \pi$ interaction was formed between the C$\mathrm{H}$ of the phenyl ring and the double bond adjacent to the lactone ring (2.872 $\AA$ ). Two more $\mathrm{C}-\mathrm{H} \cdots \mathrm{O}$ interactions existed between the oxygen atom of the ketone group and two $\mathrm{C}-\mathrm{H}$ of the neighboring phenyl groups (2.622 and $2.537 \AA$, respectively) (Figure S30). Such interactions between adjacent molecules greatly restricted their rotations and efficiently suppressed their nonradiative relaxation therefore enabled the molecules to emit intense emission in crystals. It is worth mentioning that the cooperation of those multiple interactions made it possible for the molecules to arrange in a slipped parallel manner within the crystals along the $\mathrm{a}, \mathrm{b}$, and $\mathrm{c}$ directions with intermolecular distances of $22.337,6.324$, and $18.417 \AA$, respectively (Figure S29C). Such tight packing greatly favored the AIE effect and mechanochromic luminescence of compound 2a16 as observed experimentally. 
A

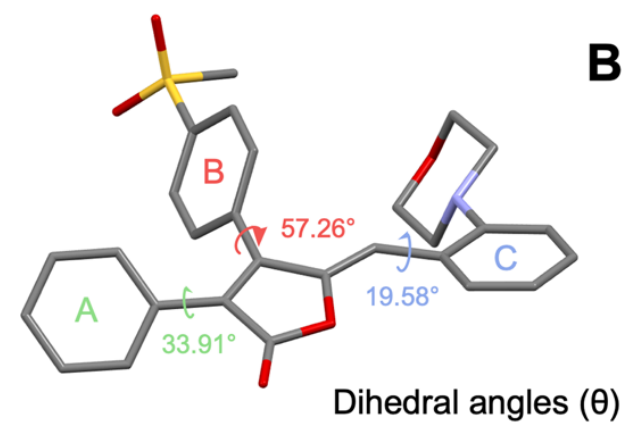
$A-B$
$A--C$
$B$-- C
$59.46^{\circ}$
$53.21^{\circ}$
$57.86^{\circ}$

C

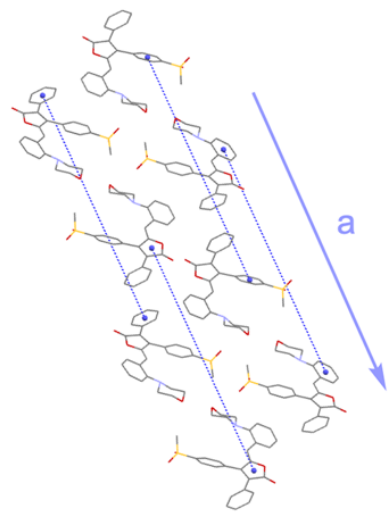

Direction a

$d=22.337 \AA$
B

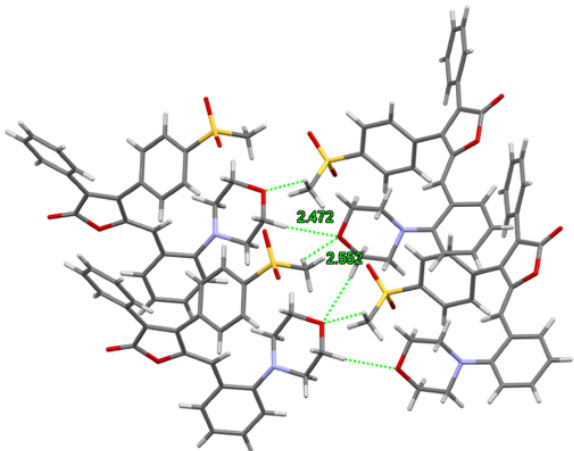

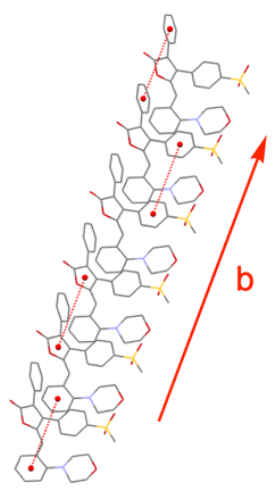

Direction b

$d=6.324 \AA$

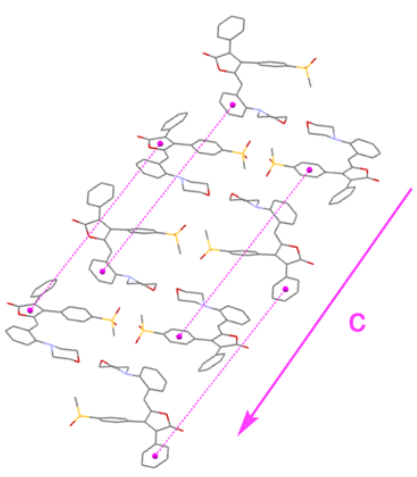

Direction c

$\mathrm{d}=18.417 \AA$

Figure S29. (A) Single crystal structure of 2a16. (B) Two dimers extracted from the single-crystal structure of $2 \mathbf{a 1 6}$ with bond lengths. (C) Molecular stacking structures along the a, b, and c directions in the crystal.
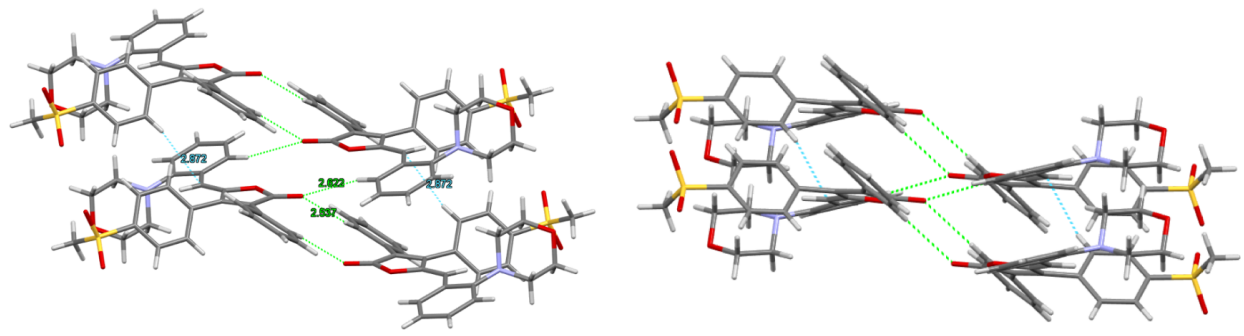

$$
\begin{aligned}
& \mathrm{C}-\mathrm{H} \cdots \mathrm{O} 2.622,2.537 \AA \\
& \mathrm{C}-\mathrm{H} \cdots \mathrm{C}\left(s p^{2}\right) \quad 2.872 \AA
\end{aligned}
$$

Side view

Figure S30. Two dimers extracted from the single-crystal structure of $\mathbf{2 a 1 6}$ with bond lengths, and side view of two dimers. 


\section{TDDFT (Time-Dependent Density Functional Theory) Calculations}

TDDFT calculations at the B3LYP/6-311++G(2d,p) level in DMSO were performed to predict the absorption and emission spectra for compounds 2a2, 2a6, 2a12 and 2a16 using Gaussian 09 package ${ }^{1}$. Solvent effects were taken into account by employing the default IEFPCM model for DMSO. The differences between LUMO and HOMO molecular orbital energies at the ground state were used to calculate the maximum absorption wavelength. The energy differences between the optimized first excited state and the corresponding ground state were used to calculate the emission spectra by applying Franck-Condon principle. The calculated spectra were shown in Table S2.

14.1 Table S2. Calculations of Absorption and Emission Spectra for Compounds 2a2, 2a6 and 2 a12

\begin{tabular}{ccccccccc}
\hline \multirow{2}{*}{ Cpds } & HOMO & LUMO & Energy Gap & Energy Gap & $\lambda$ abs(nm) & $\lambda$ abs $(\mathrm{nm})$ & $\lambda$ em(nm) & $\lambda$ em(nm) \\
\cline { 6 - 9 } & (Hartree) & (Hartree) & $($ Hartree) & $(\mathrm{eV})$ & Calc & Exp & Calc & Exp \\
\hline $\mathbf{2 a 2}$ & -.22835 & -.10749 & 0.12086 & 3.28877 & 377 & 364 & 536 & 461 \\
$\mathbf{2 a 6}$ & -.21847 & -.10421 & 0.11426 & 3.10917 & 399 & 394 & 551 & 547 \\
$\mathbf{2 a 1 2}$ & -0.1977 & -0.09949 & 0.09821 & 2.67243 & 464 & 464 & 618 & 656 \\
\hline
\end{tabular}

\subsection{The Coordinates of the Optimized Geometries}

compound 2a2

Energy: -1019354.7318759

$\begin{array}{lrrr}\mathrm{O} & 5.42035 & -1.69055 & -0.73683 \\ \mathrm{~S} & 4.40298 & -2.46222 & -0.00700 \\ \mathrm{C} & 2.88611 & -1.48720 & 0.01681 \\ \mathrm{C} & 1.97041 & -1.67319 & 1.05219 \\ \mathrm{C} & 0.79849 & -0.91801 & 1.06619 \\ \mathrm{C} & 0.54197 & 0.02653 & 0.05781 \\ \mathrm{C} & -0.70493 & 0.82282 & 0.06638 \\ \mathrm{C} & -0.85339 & 2.18396 & 0.02389 \\ \mathrm{C} & 0.14322 & 3.26321 & 0.06503 \\ \mathrm{C} & 1.34946 & 3.11699 & 0.77626 \\ \mathrm{C} & 2.28765 & 4.14505 & 0.80448 \\ \mathrm{C} & 2.04121 & 5.34099 & 0.12590 \\ \mathrm{C} & 0.84301 & 5.50384 & -0.57125 \\ \mathrm{C} & -0.10196 & 4.48025 & -0.59905 \\ \mathrm{C} & -2.31068 & 2.45913 & -0.01919 \\ \mathrm{O} & -2.96940 & 1.23043 & 0.02189 \\ \mathrm{C} & -2.03329 & 0.22196 & 0.05533 \\ \mathrm{C} & -2.37064 & -1.09003 & 0.02793 \\ \mathrm{C} & -3.68139 & -1.72360 & -0.00341 \\ \mathrm{C} & -3.72361 & -3.13376 & -0.04121 \\ \mathrm{C} & -4.93336 & -3.81956 & -0.07183 \\ & & & 533\end{array}$




$\begin{array}{lrrr}\mathrm{C} & -6.13651 & -3.11047 & -0.06438 \\ \mathrm{H} & -7.08408 & -3.64163 & -0.08772 \\ \mathrm{C} & -6.11409 & -1.71340 & -0.02644 \\ \mathrm{C} & -4.90690 & -1.02174 & 0.00347 \\ \mathrm{O} & -2.92826 & 3.49212 & -0.07539 \\ \mathrm{C} & 1.48747 & 0.20490 & -0.96684 \\ \mathrm{C} & 2.65863 & -0.54679 & -0.99039 \\ \mathrm{C} & 3.97529 & -3.89690 & -1.02604 \\ \mathrm{O} & 4.64400 & -2.94674 & 1.36083 \\ \mathrm{H} & 2.18787 & -2.38220 & 1.84440 \\ \mathrm{H} & 0.08659 & -1.04322 & 1.87640 \\ \mathrm{H} & 1.54357 & 2.20149 & 1.32485 \\ \mathrm{H} & 3.20986 & 4.01409 & 1.36387 \\ \mathrm{H} & 2.77456 & 6.14247 & 0.14838 \\ \mathrm{H} & 0.63879 & 6.43402 & -1.09445 \\ \mathrm{H} & -1.03721 & 4.61994 & -1.12797 \\ \mathrm{H} & -1.52590 & -1.77270 & 0.02625 \\ \mathrm{H} & -2.78910 & -3.69026 & -0.04671 \\ \mathrm{H} & -4.93834 & -4.90576 & -0.10094 \\ \mathrm{H} & -7.04693 & -1.15614 & -0.02020 \\ \mathrm{H} & -4.90571 & 0.06040 & 0.03208 \\ \mathrm{H} & 1.30097 & 0.94112 & -1.74212 \\ \mathrm{H} & 3.40087 & -0.39557 & -1.76760 \\ \mathrm{H} & 3.69718 & -3.55899 & -2.02620 \\ \mathrm{H} & 4.87375 & -4.51768 & -1.07167 \\ \mathrm{H} & 3.15887 & -4.44570 & -0.55263\end{array}$

compound 2a6

Energy: -1066557.1370296

$\begin{array}{lrrr}\mathrm{O} & 5.29425 & -2.61189 & -0.74836 \\ \mathrm{~S} & 4.15284 & -3.17352 & -0.01008 \\ \mathrm{C} & 2.84673 & -1.93152 & 0.01205 \\ \mathrm{C} & 1.90809 & -1.94636 & 1.04366 \\ \mathrm{C} & 0.90017 & -0.98325 & 1.05904 \\ \mathrm{C} & 0.83096 & -0.00147 & 0.05588 \\ \mathrm{C} & -0.24128 & 1.01796 & 0.06604 \\ \mathrm{C} & -0.12578 & 2.38398 & 0.02225 \\ \mathrm{C} & 1.05959 & 3.25206 & 0.06322 \\ \mathrm{C} & 2.21757 & 2.87687 & 0.77083 \\ \mathrm{C} & 3.33422 & 3.70785 & 0.80056 \\ \mathrm{C} & 3.31852 & 4.93183 & 0.12751 \\ \mathrm{C} & 2.17193 & 5.32172 & -0.56638 \\ \mathrm{C} & 1.04980 & 4.49619 & -0.59603 \\ \mathrm{C} & -1.50160 & 2.93292 & -0.01878\end{array}$




$\begin{array}{lrrr}\mathrm{O} & -2.38350 & 1.85292 & 0.02537 \\ \mathrm{C} & -1.65694 & 0.68277 & 0.05905 \\ \mathrm{C} & -2.24535 & -0.53929 & 0.03406 \\ \mathrm{C} & -3.65103 & -0.90079 & 0.00731 \\ \mathrm{C} & -3.98321 & -2.27442 & -0.01735 \\ \mathrm{C} & -5.29825 & -2.71141 & -0.04245 \\ \mathrm{C} & -6.33691 & -1.77184 & -0.04301 \\ \mathrm{O} & -7.61355 & -2.24628 & -0.06762 \\ \mathrm{C} & -6.03626 & -0.40323 & -0.01876 \\ \mathrm{C} & -4.71616 & 0.02681 & 0.00582 \\ \mathrm{O} & -1.91211 & 4.06531 & -0.07562 \\ \mathrm{C} & 1.79678 & -0.00041 & -0.96536 \\ \mathrm{C} & 2.80454 & -0.96016 & -0.99079 \\ \mathrm{C} & 3.45985 & -4.51061 & -1.01641 \\ \mathrm{O} & 4.30480 & -3.68625 & 1.36035 \\ \mathrm{H} & 1.98430 & -2.68708 & 1.83307 \\ \mathrm{H} & 0.17459 & -0.97488 & 1.86668 \\ \mathrm{H} & 2.23562 & 1.93875 & 1.31530 \\ \mathrm{H} & 4.21575 & 3.40148 & 1.35705 \\ \mathrm{H} & 4.19076 & 5.57942 & 0.15138 \\ \mathrm{H} & 2.14721 & 6.27593 & -1.08569 \\ \mathrm{H} & 0.15714 & 4.81317 & -1.12195 \\ \mathrm{H} & -1.55097 & -1.37451 & 0.03231 \\ \mathrm{H} & -3.18279 & -3.01056 & -0.01657 \\ \mathrm{H} & -5.54346 & -3.76837 & -0.06123 \\ \mathrm{H} & -8.23211 & -1.49870 & -0.06410 \\ \mathrm{H} & -6.84225 & 0.32852 & -0.01932 \\ \mathrm{H} & -4.50387 & 1.08808 & 0.02385 \\ \mathrm{H} & 1.75609 & 0.76258 & -1.73603 \\ \mathrm{H} & 3.56470 & -0.94856 & -1.76522 \\ \mathrm{H} & 3.24811 & -4.13581 & -2.01968 \\ \mathrm{H} & 4.22508 & -5.29001 & -1.05607 \\ \mathrm{H} & 2.55569 & -4.89096 & -0.53724\end{array}$

compound 2a12

Energy: -1103424.6780460

$\begin{array}{llll}\mathrm{O} & 5.46686 & -3.26331 & -0.73797 \\ \mathrm{~S} & 4.25172 & -3.65295 & -0.00625 \\ \mathrm{C} & 3.14235 & -2.23329 & 0.01766 \\ \mathrm{C} & 2.21069 & -2.11095 & 1.04843 \\ \mathrm{C} & 1.35281 & -1.01205 & 1.06146 \\ \mathrm{C} & 1.42540 & -0.03203 & 0.05673 \\ \mathrm{C} & 0.50999 & 1.13008 & 0.06572 \\ \mathrm{C} & 0.82133 & 2.46733 & 0.01978\end{array}$




\begin{tabular}{|c|c|c|c|}
\hline $\mathrm{C}$ & 2.12020 & 3.15404 & 0.05972 \\
\hline $\mathrm{C}$ & 3.21281 & 2.61494 & 0.76554 \\
\hline $\mathrm{C}$ & 4.43905 & 3.27379 & 0.79276 \\
\hline $\mathrm{C}$ & 4.60133 & 4.48734 & 0.12034 \\
\hline $\mathrm{C}$ & 3.52189 & 5.04057 & -0.57040 \\
\hline $\mathrm{C}$ & 2.29152 & 4.38704 & -0.59854 \\
\hline $\mathrm{C}$ & -0.45925 & 3.20691 & -0.02198 \\
\hline $\mathrm{O}$ & -1.48636 & 2.26472 & 0.02515 \\
\hline $\mathrm{C}$ & -0.93533 & 1.00156 & 0.05994 \\
\hline $\mathrm{C}$ & -1.69678 & -0.12421 & 0.03327 \\
\hline $\mathrm{C}$ & -3.13385 & -0.28108 & 0.00894 \\
\hline $\mathrm{C}$ & -3.66632 & -1.58838 & -0.02762 \\
\hline $\mathrm{C}$ & -5.02787 & -1.83586 & -0.05015 \\
\hline $\mathrm{C}$ & -5.95813 & -0.76690 & -0.03848 \\
\hline $\mathrm{N}$ & -7.31680 & -0.99506 & -0.06797 \\
\hline $\mathrm{C}$ & -8.24651 & 0.11970 & 0.01863 \\
\hline $\mathrm{C}$ & -7.82712 & -2.35582 & -0.05475 \\
\hline $\mathrm{C}$ & -5.43023 & 0.54911 & 0.00340 \\
\hline $\mathrm{C}$ & -4.06641 & 0.78216 & 0.02421 \\
\hline $\mathrm{O}$ & -0.70379 & 4.38770 & -0.08158 \\
\hline $\mathrm{C}$ & 2.38251 & -0.17233 & -0.96335 \\
\hline $\mathrm{C}$ & 3.24145 & -1.26721 & -0.98629 \\
\hline $\mathrm{C}$ & 3.37353 & -4.86820 & -1.02260 \\
\hline $\mathrm{O}$ & 4.32195 & -4.19101 & 1.36132 \\
\hline $\mathrm{H}$ & 2.17871 & -2.85429 & 1.83840 \\
\hline $\mathrm{H}$ & 0.63565 & -0.89776 & 1.86857 \\
\hline $\mathrm{H}$ & 3.09478 & 1.68466 & 1.31097 \\
\hline $\mathrm{H}$ & 5.26743 & 2.84156 & 1.34761 \\
\hline $\mathrm{H}$ & 5.55884 & 5.00070 & 0.14257 \\
\hline $\mathrm{H}$ & 3.63497 & 5.98881 & -1.08912 \\
\hline $\mathrm{H}$ & 1.45290 & 4.83056 & -1.12199 \\
\hline $\mathrm{H}$ & -1.12887 & -1.05056 & 0.02765 \\
\hline $\mathrm{H}$ & -2.98294 & -2.43499 & -0.03696 \\
\hline $\mathrm{H}$ & -5.37193 & -2.86281 & -0.07434 \\
\hline $\mathrm{H}$ & -8.11259 & 0.82165 & -0.81489 \\
\hline $\mathrm{H}$ & -9.26770 & -0.26178 & -0.02634 \\
\hline $\mathrm{H}$ & -8.13241 & 0.68056 & 0.95736 \\
\hline $\mathrm{H}$ & -7.53770 & -2.89843 & 0.85715 \\
\hline $\mathrm{H}$ & -8.91681 & -2.33067 & -0.10220 \\
\hline $\mathrm{H}$ & -7.46632 & -2.92869 & -0.91929 \\
\hline $\mathrm{H}$ & -6.09731 & 1.40254 & 0.02000 \\
\hline $\mathrm{H}$ & -3.71030 & 1.80444 & 0.05450 \\
\hline $\mathrm{H}$ & 2.45256 & 0.58723 & -1.73532 \\
\hline $\mathrm{H}$ & 3.99574 & -1.36618 & -1.76030 \\
\hline
\end{tabular}




$\begin{array}{llll}\mathrm{H} & 3.22328 & -4.46062 & -2.02418 \\ \mathrm{H} & 4.01541 & -5.75187 & -1.06487 \\ \mathrm{H} & 2.42106 & -5.11363 & -0.54891\end{array}$

\section{Docking Study of 2 a16 in the Active Site of COX-2}

The experimental crystallographic structure of COX-2 complex were retrieved from the Protein Data Bank (PDB: 5KIR). The molecular model of the compounds was built by Discovery Studio 3.5. Both the proteins and the ligands were prepared by adding polar hydrogen atoms and partial charges with the assistance of AutoDockTools 1.5.6. The molecular docking was carried out by AutoDock 4.2. Grid points were set at 50 at $x, y, z$ axes. The number of Dock runs was set at 20 . All other parameters were kept as their default values.

\section{The NMR spectra of the target compounds}

${ }^{1} \mathrm{H}-\mathrm{NMR}$ (600 MHz, DMSO- $d_{6}$ ) for $\mathbf{2 a 1}$

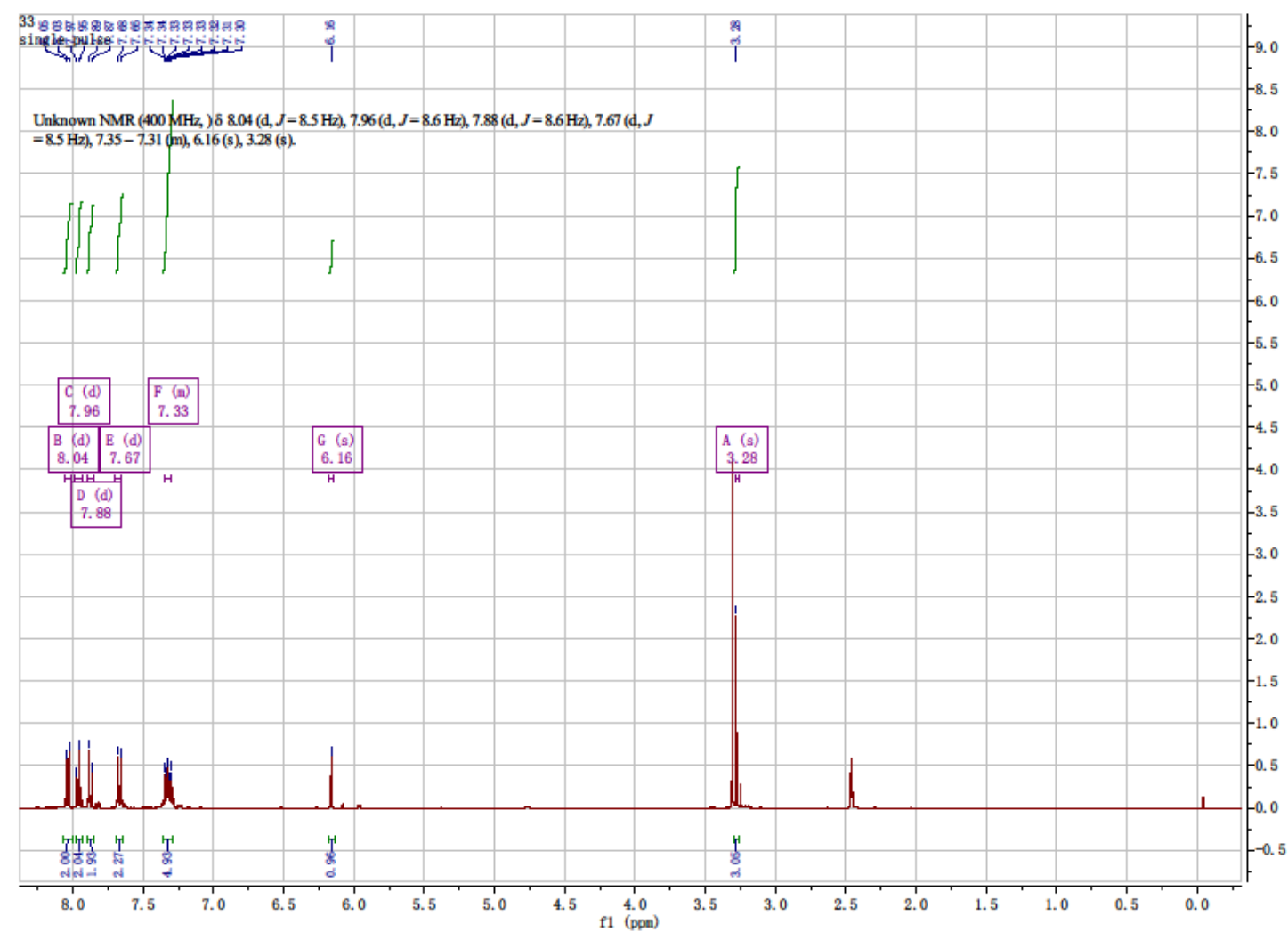


${ }^{13} \mathrm{C}-\mathrm{NMR}$ (151 MHz, DMSO-d6) for $\mathbf{2 a 1}$

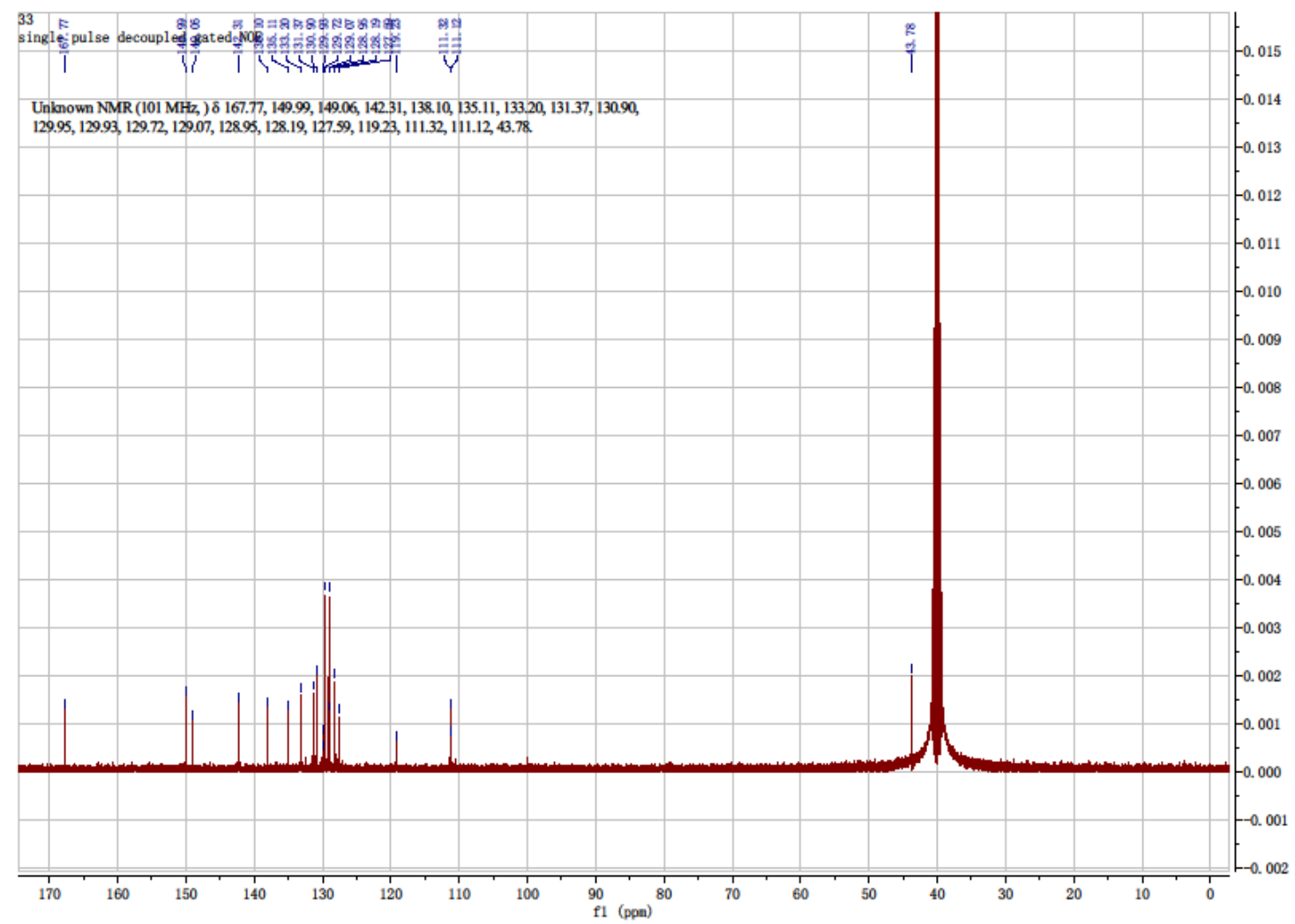

${ }^{1} \mathrm{H}-\mathrm{NMR}$ (600 MHz, DMSO-d6) for $\mathbf{2 a 2}$

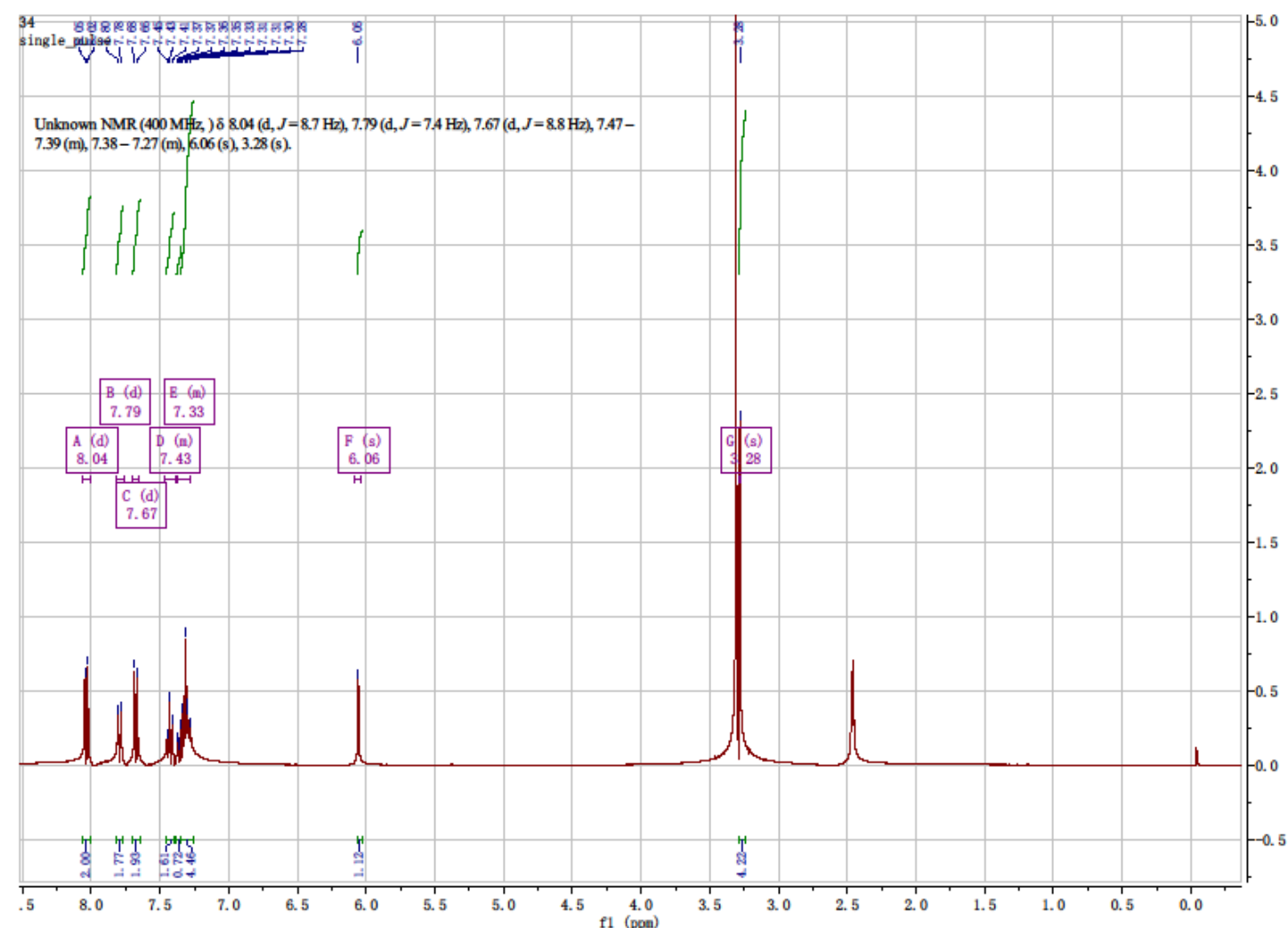


${ }^{13} \mathrm{C}-\mathrm{NMR}$ (151 MHz, DMSO-d6) for $\mathbf{2 a 2}$

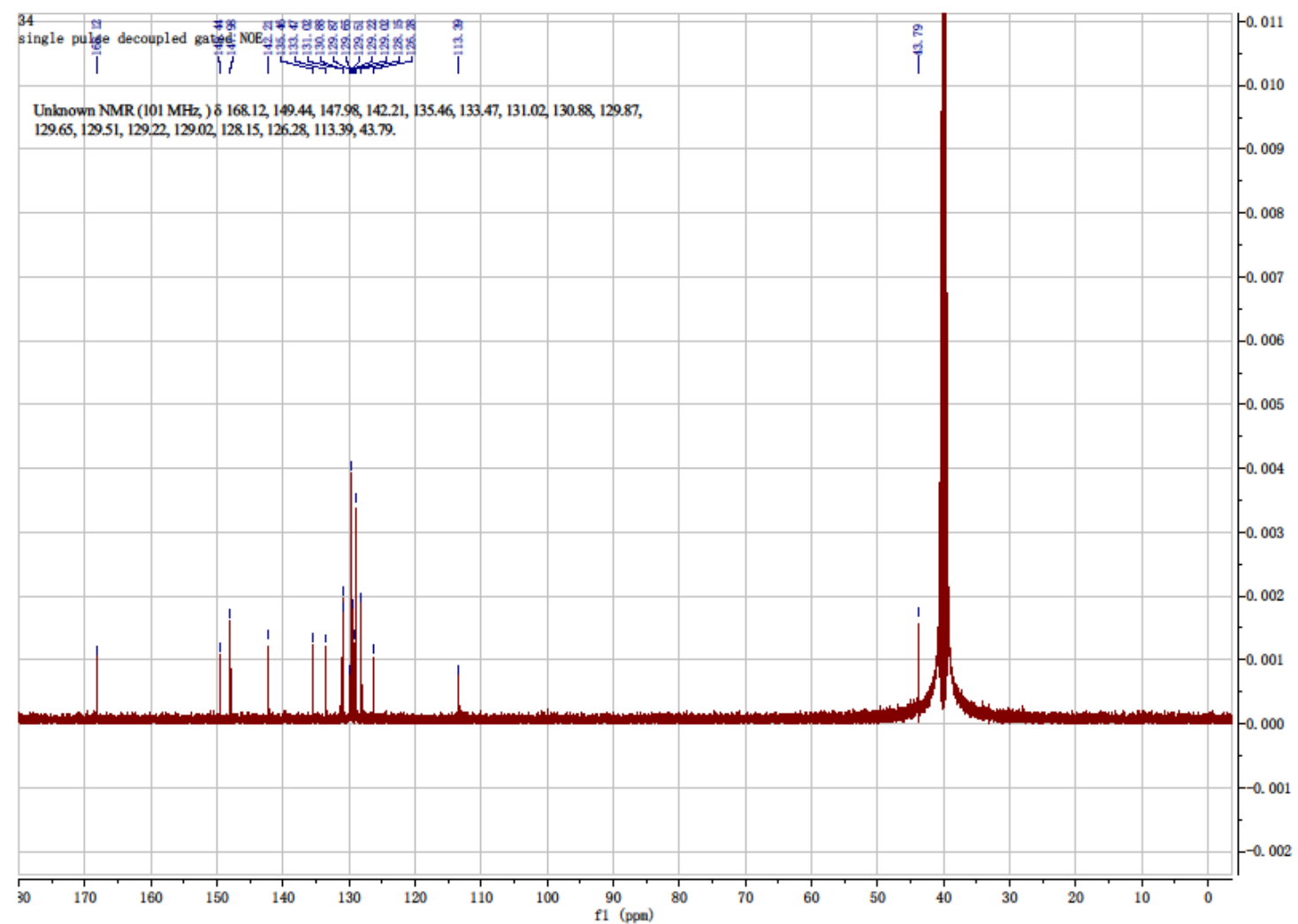


${ }^{1} \mathrm{H}-\mathrm{NMR}$ (600 MHz, DMSO-d6) for $\mathbf{2 a 3}$

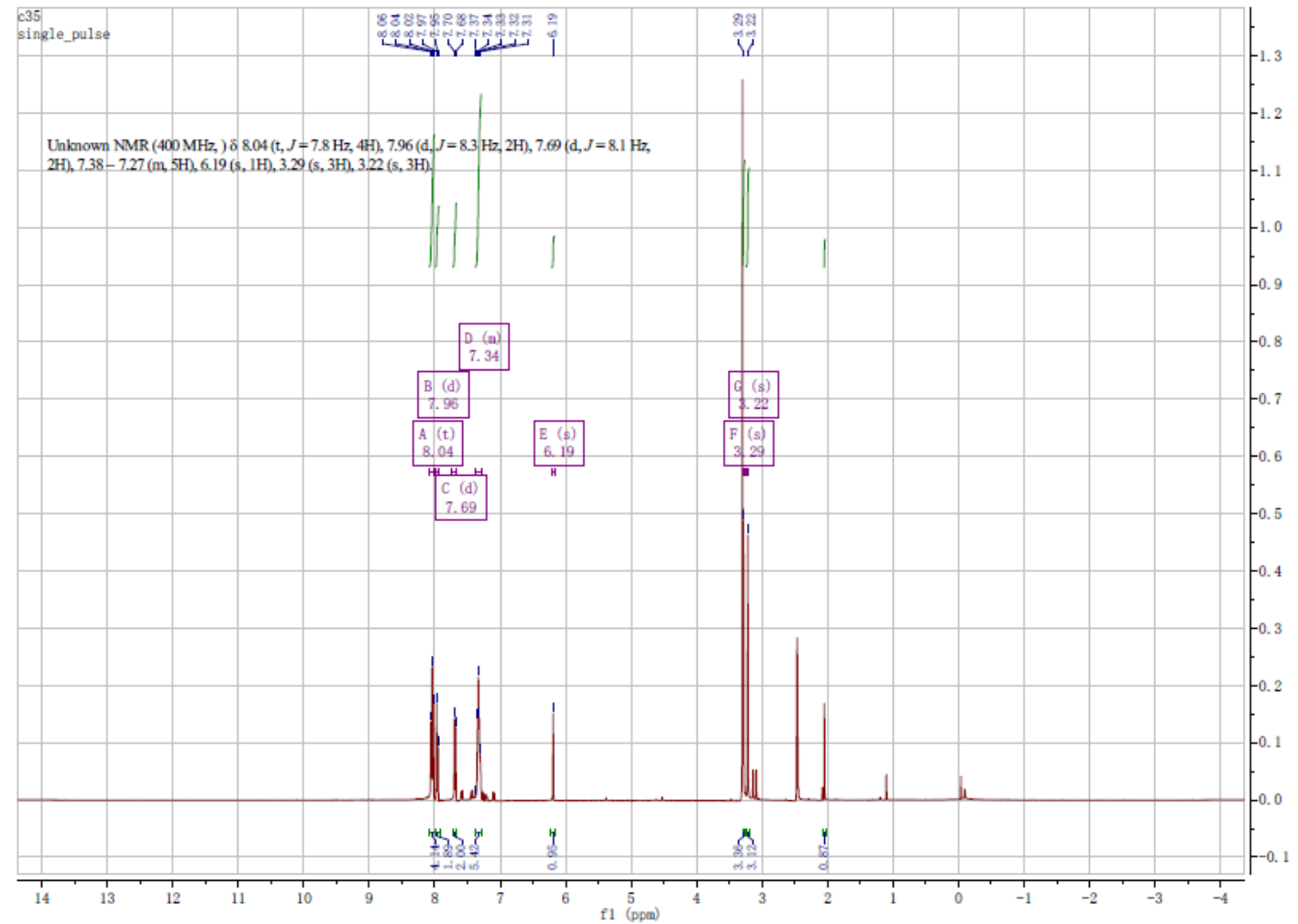

${ }^{13} \mathrm{C}-\mathrm{NMR}$ (151 MHz, DMSO-d6) for $\mathbf{2 a 3}$

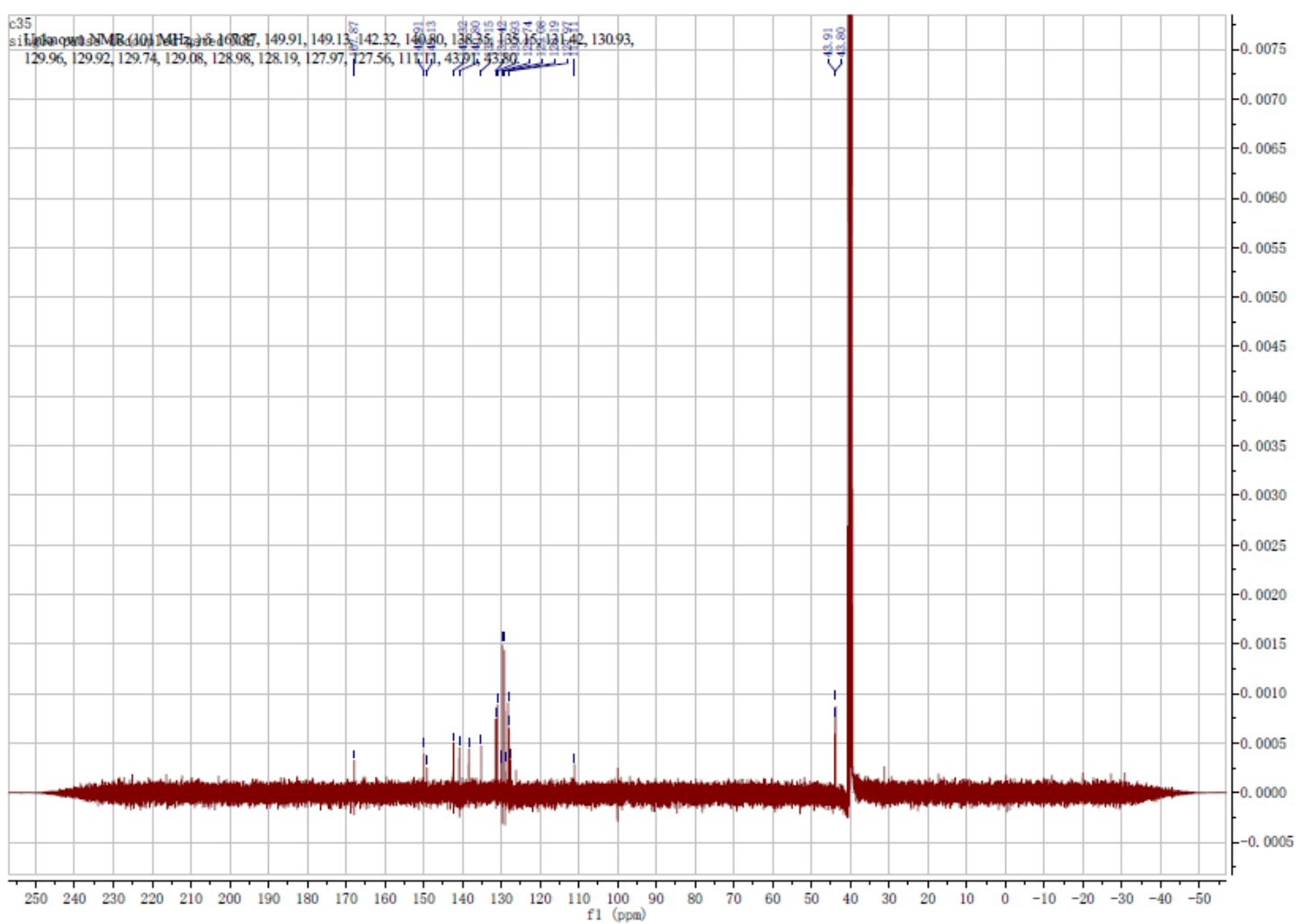


${ }^{1} \mathrm{H}-\mathrm{NMR}$ (600 MHz, DMSO-d6) for 2a4

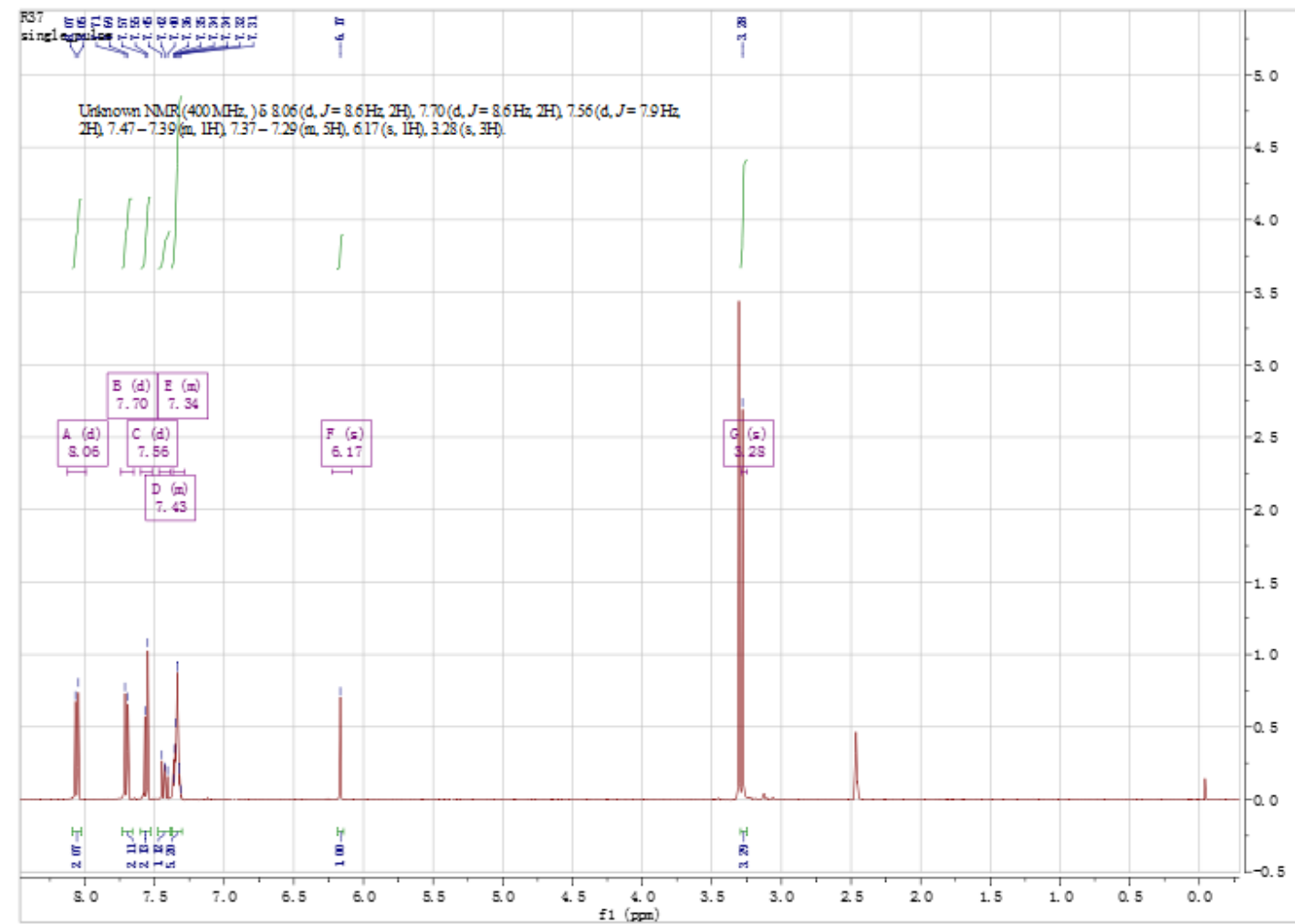

${ }^{13} \mathrm{C}-\mathrm{NMR}$ (151 MHz, DMSO-d6) for $\mathbf{2 a 4}$

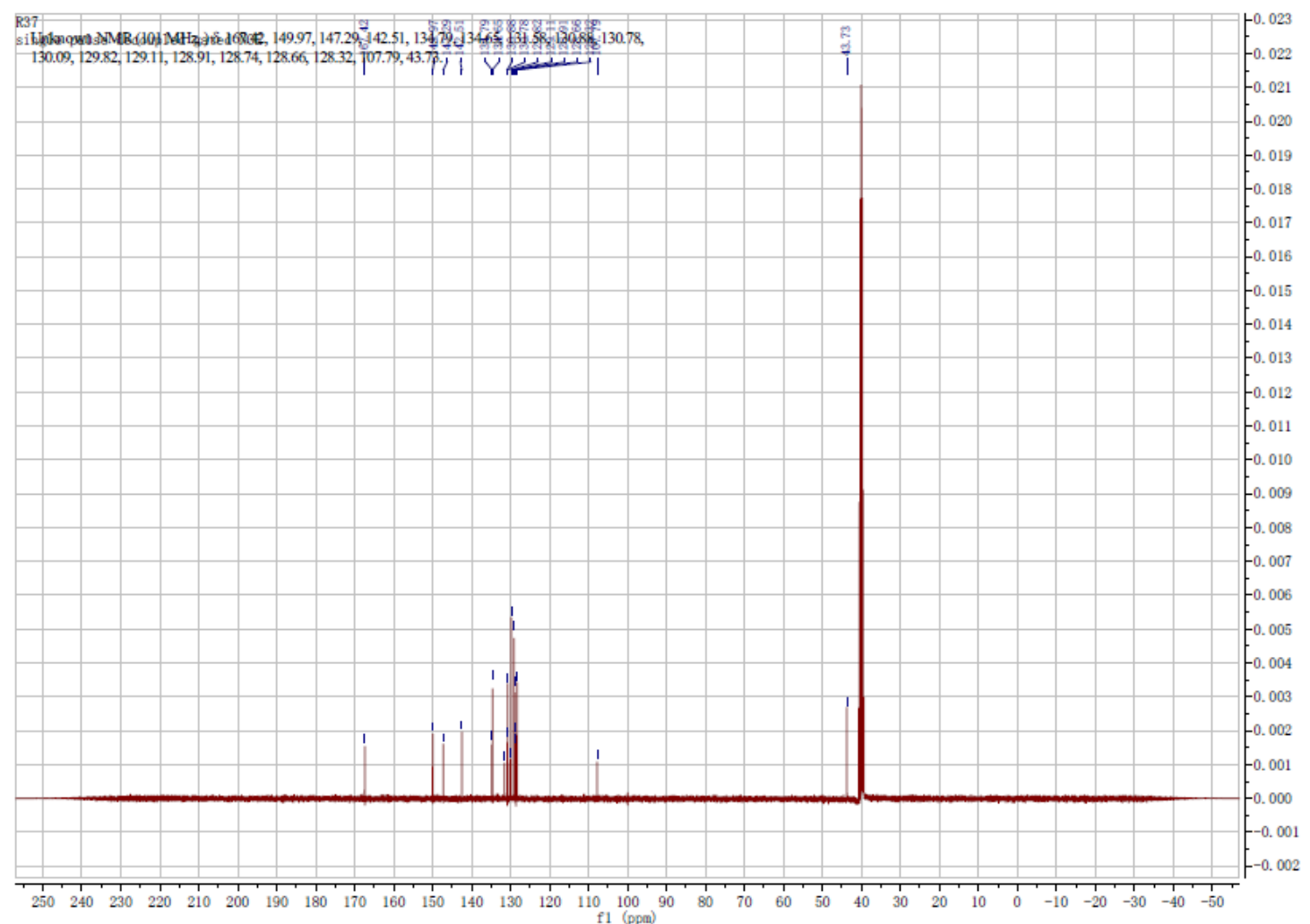


${ }^{1} \mathrm{H}-\mathrm{NMR}$ (600 MHz, DMSO-d6) for $\mathbf{2 a 5}$

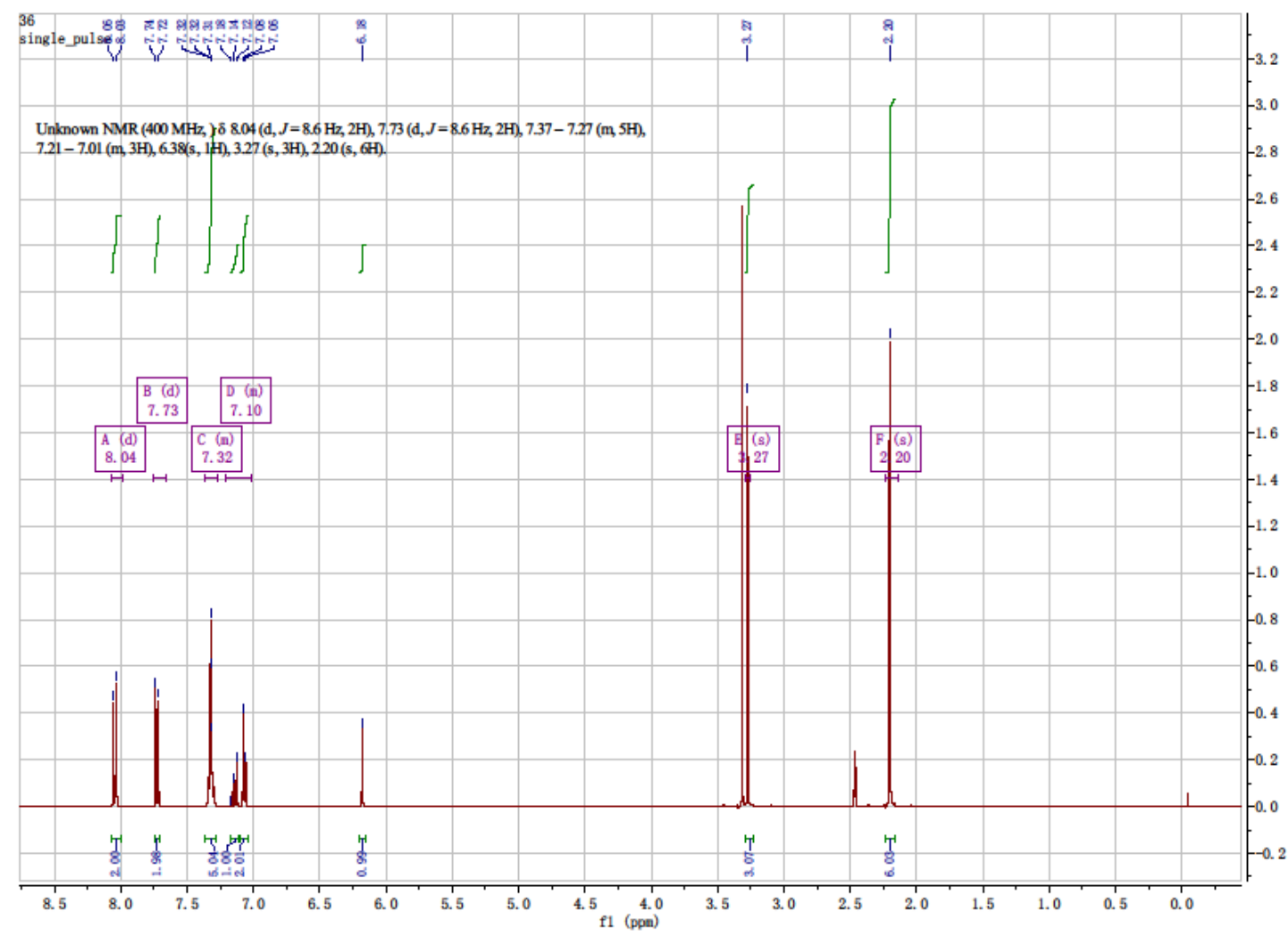

${ }^{13} \mathrm{C}-\mathrm{NMR}$ (151 MHz, DMSO-d6) for $\mathbf{2 a 5}$

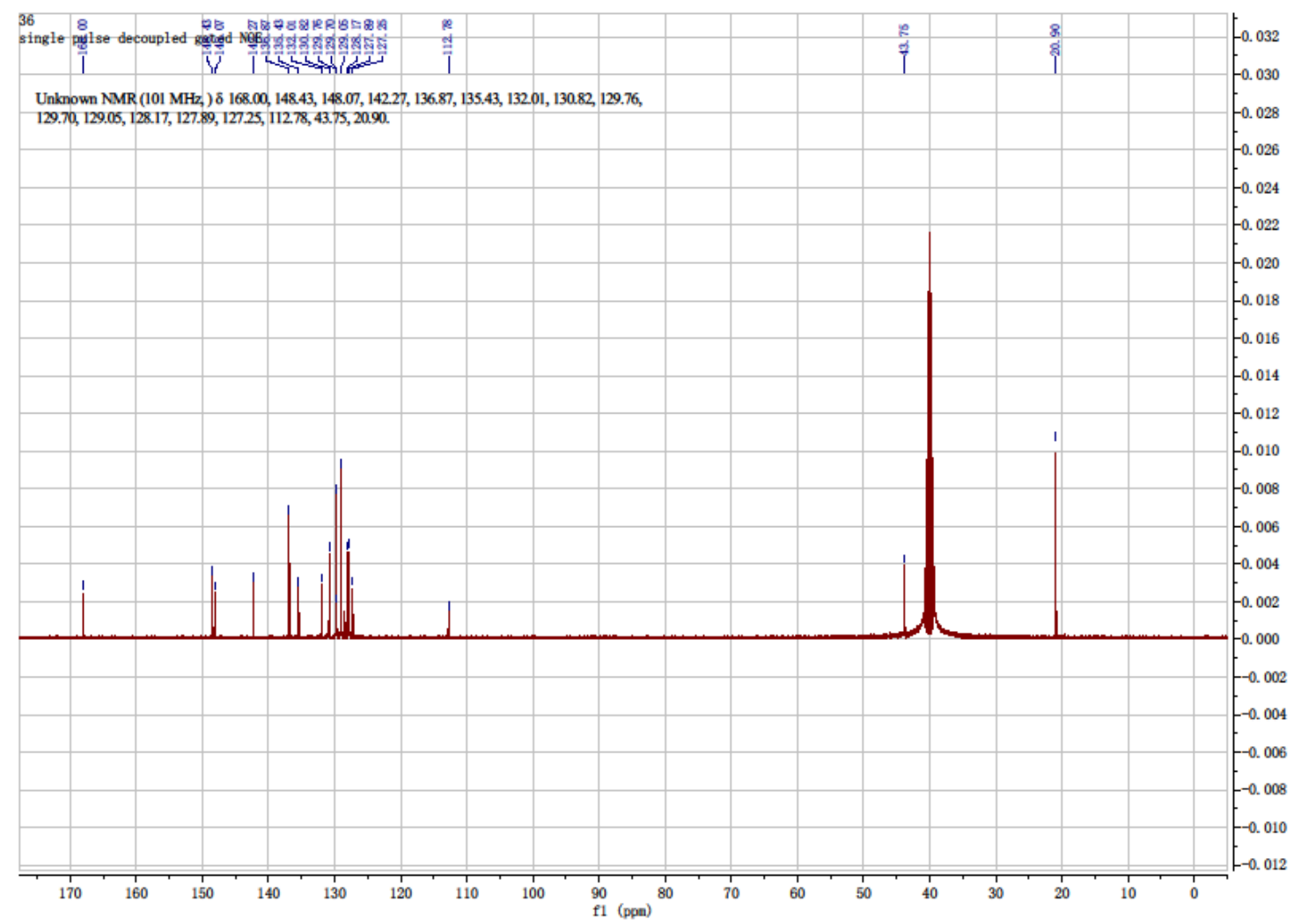


${ }^{1} \mathrm{H}-\mathrm{NMR}$ (600 MHz, DMSO-d6) for $\mathbf{2 a 6}$

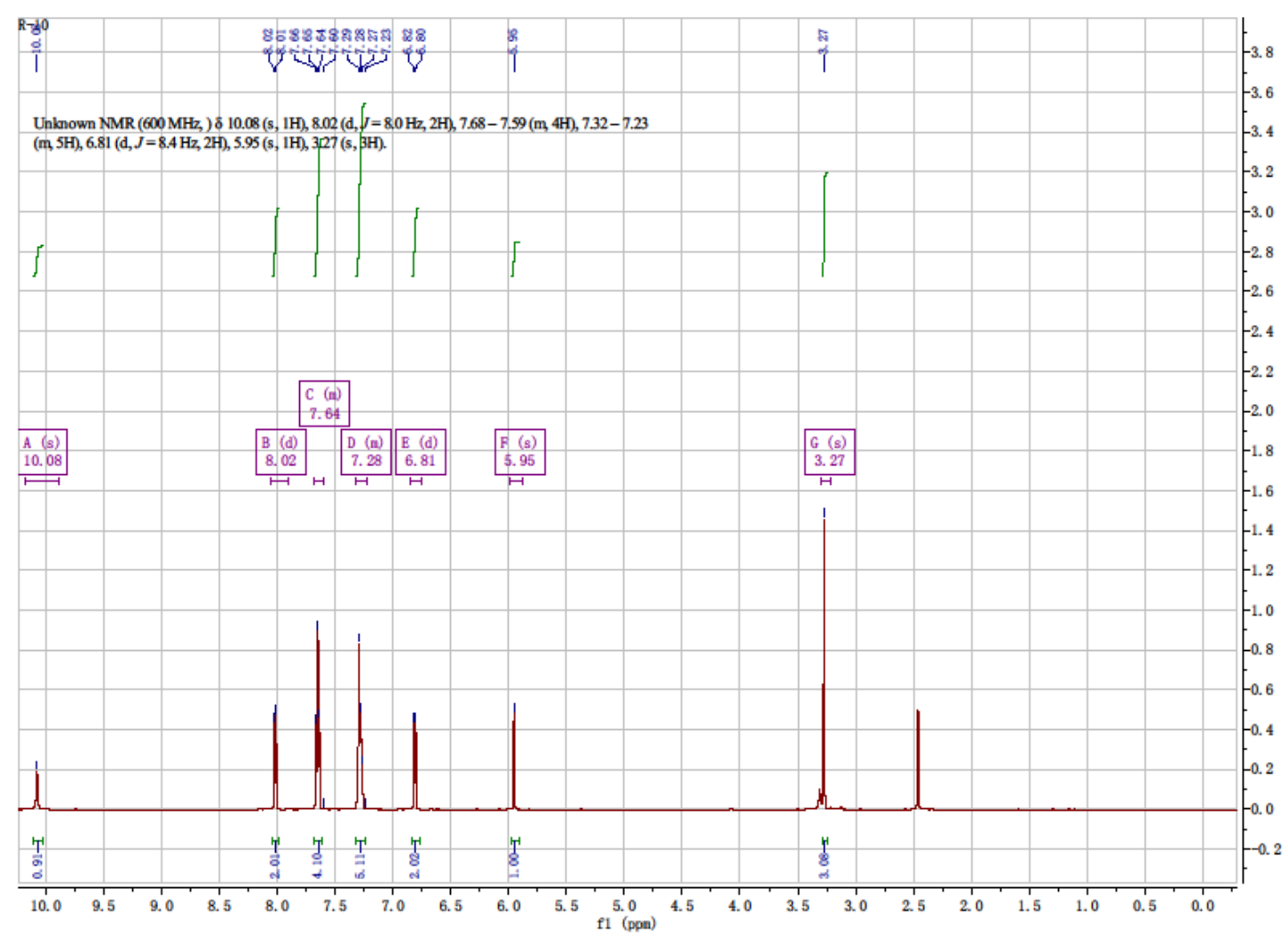

${ }^{13} \mathrm{C}-\mathrm{NMR}$ (151 MHz, DMSO-d6) for $\mathbf{2 a 6}$

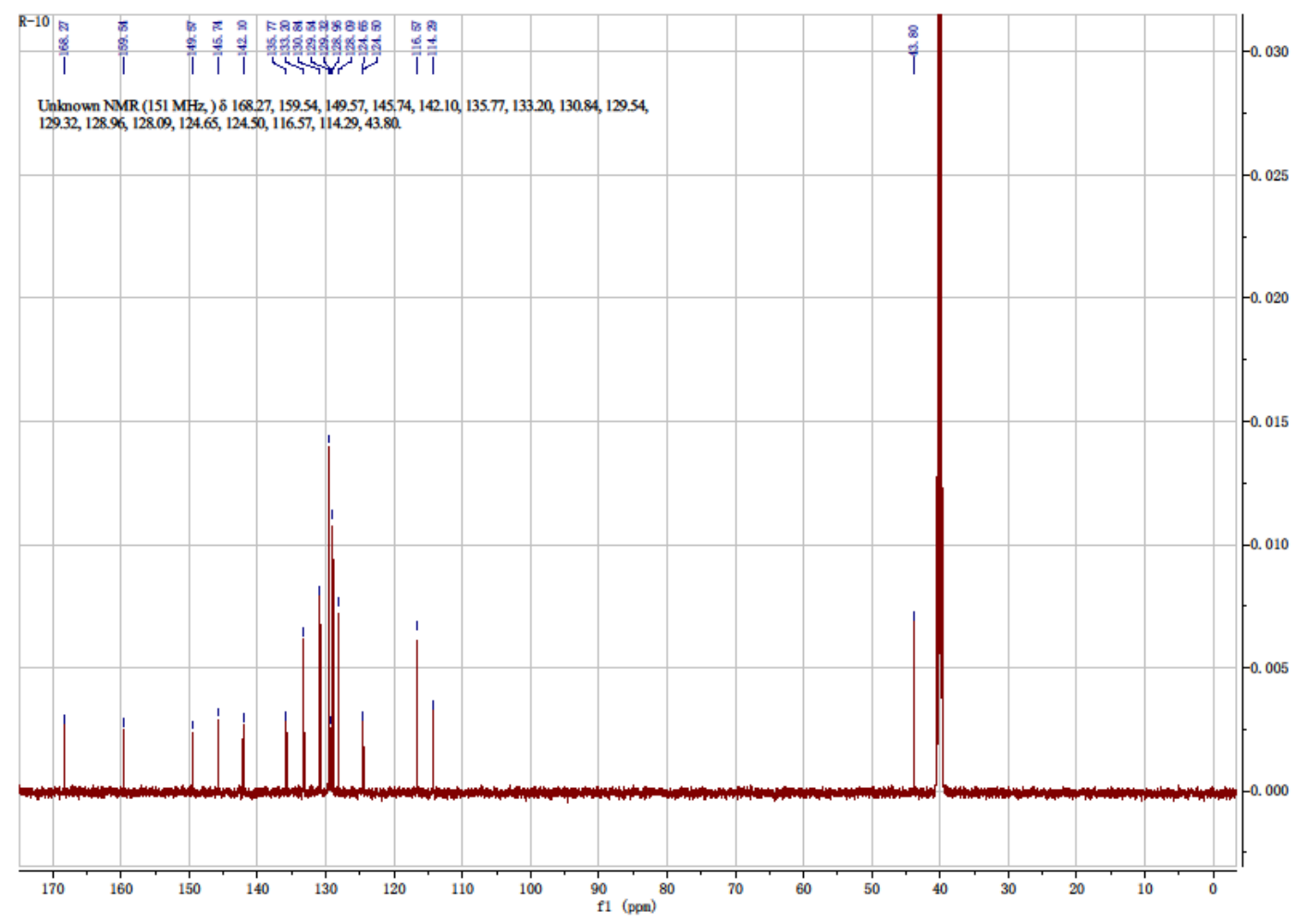


${ }^{1} \mathrm{H}-\mathrm{NMR}$ (600 MHz, DMSO-d6) for $\mathbf{2 a} 7$

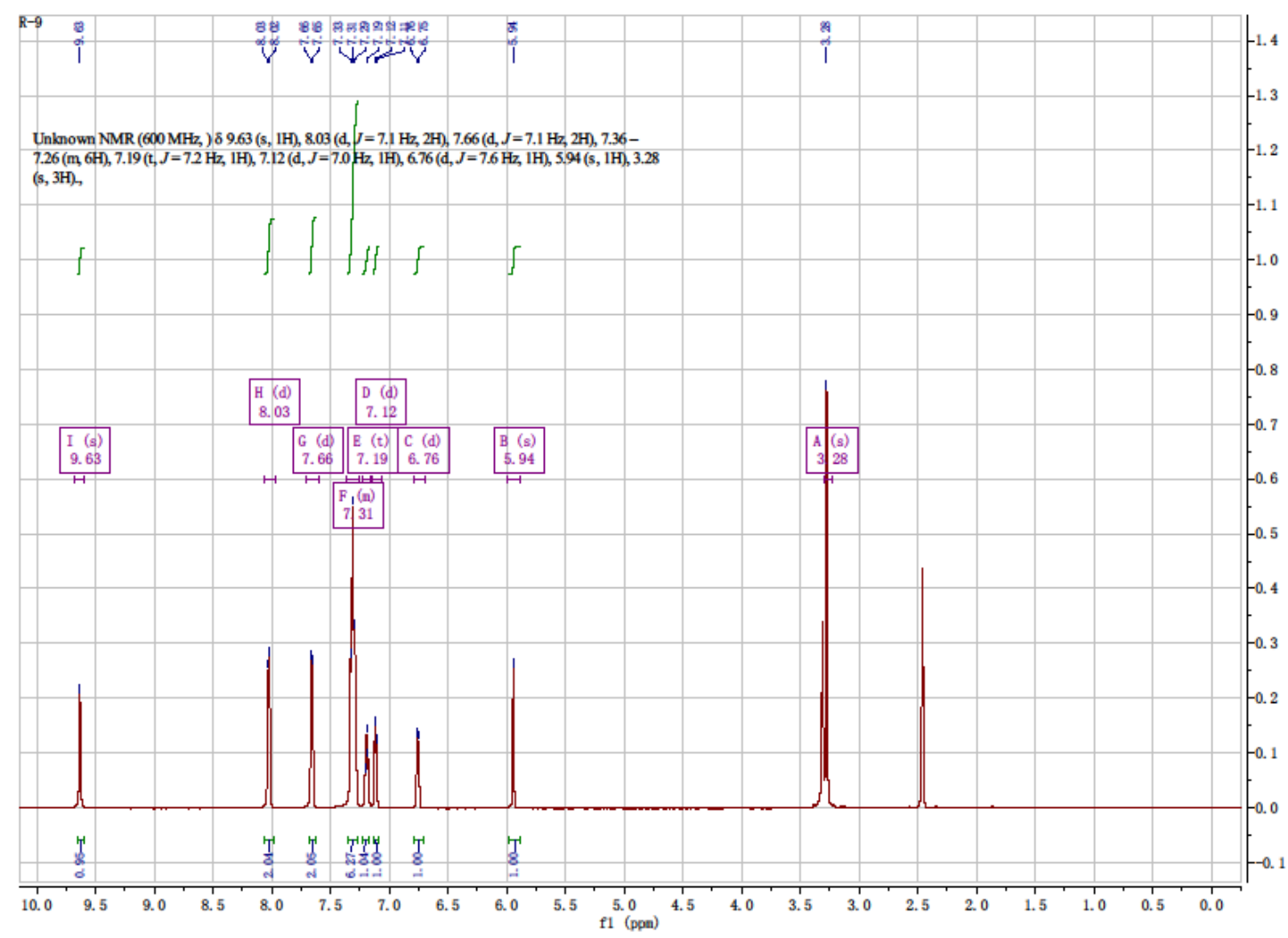

${ }^{13} \mathrm{C}-\mathrm{NMR}$ (151 MHz, DMSO-d6) for $\mathbf{2 a} 7$

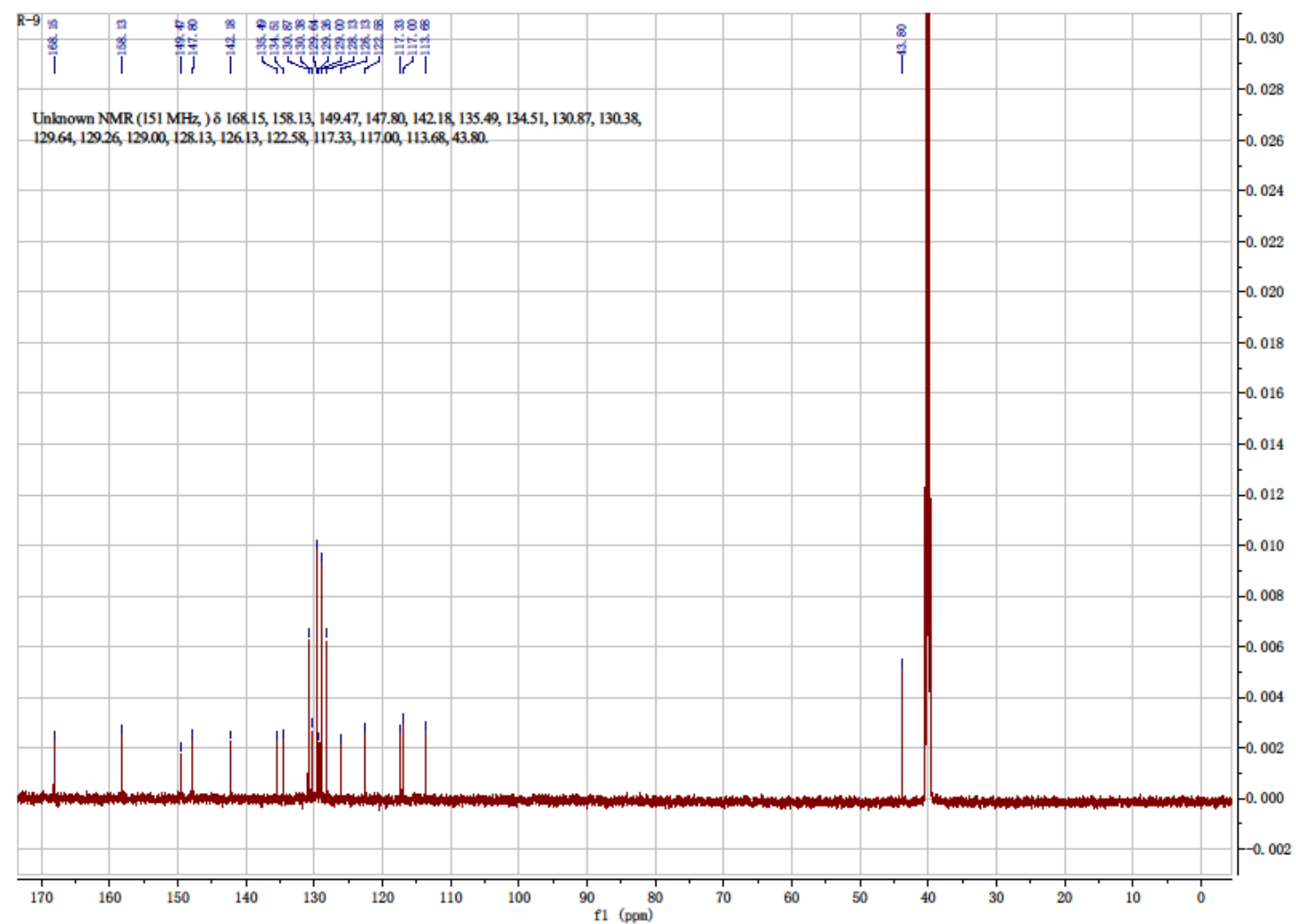


${ }^{1} \mathrm{H}-\mathrm{NMR}$ (600 MHz, DMSO-d6) for $\mathbf{2 a 8}$

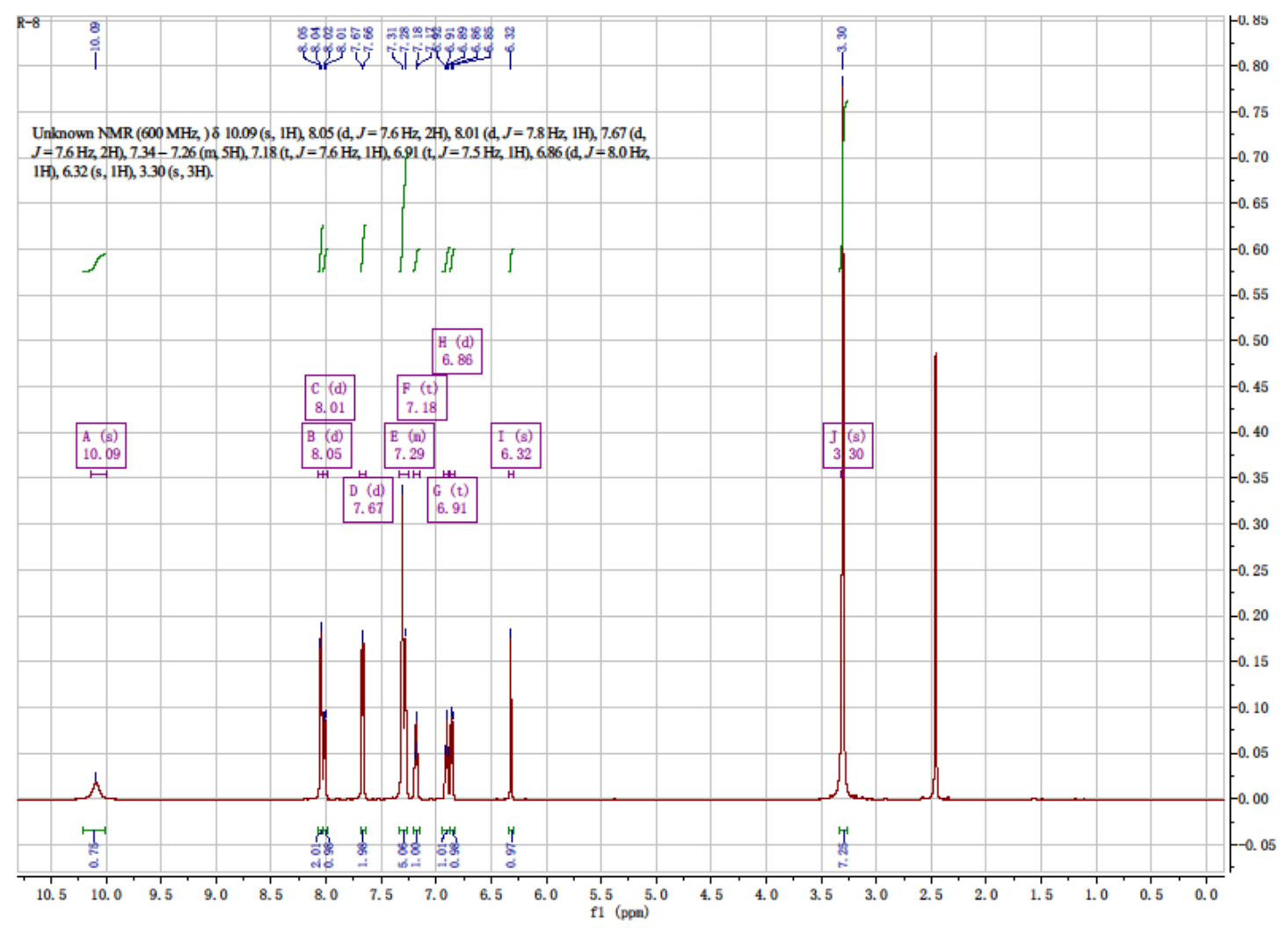

${ }^{13} \mathrm{C}-\mathrm{NMR}$ (151 MHz, DMSO-d6) for $\mathbf{2 a 8}$

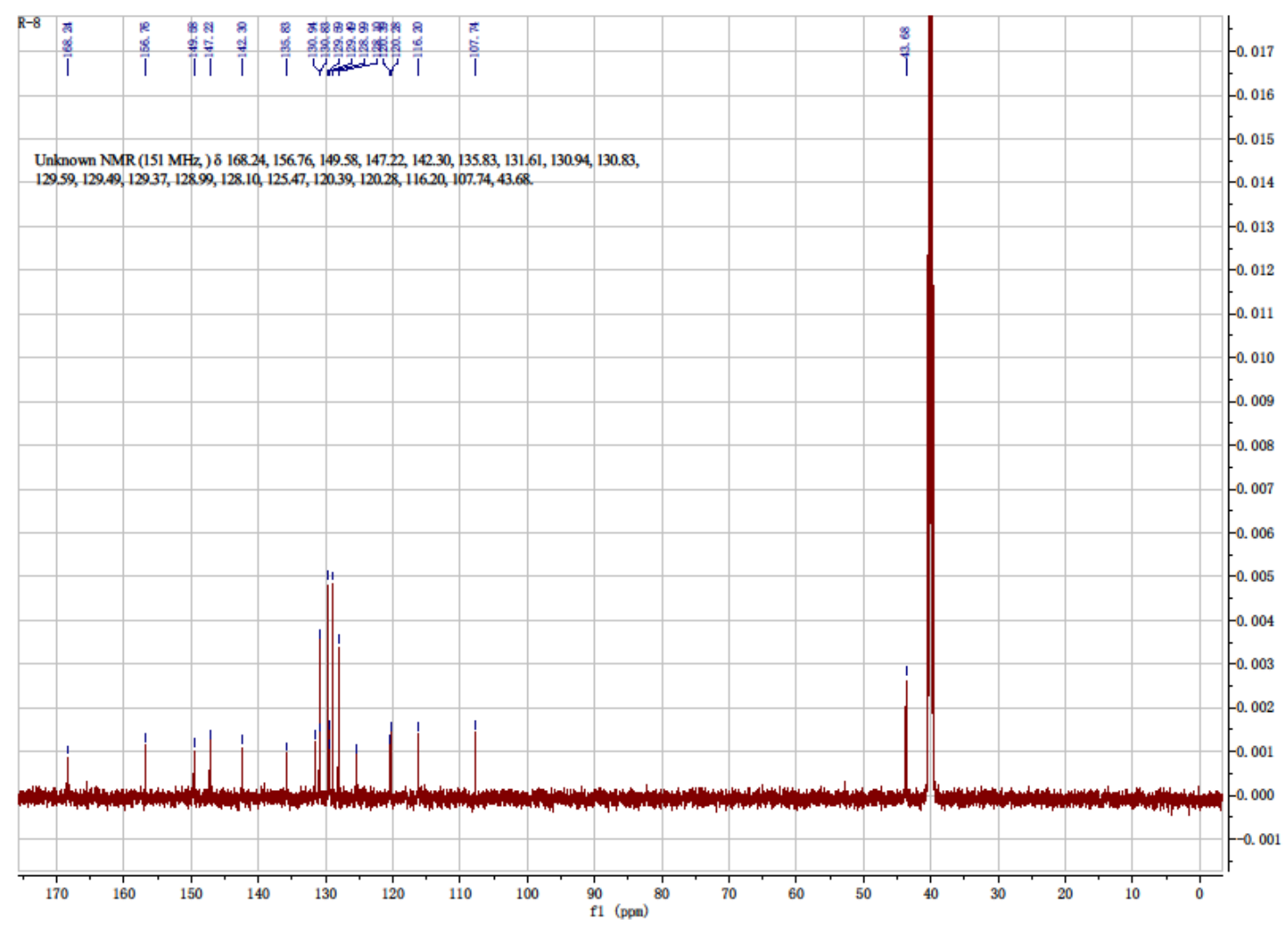


${ }^{1} \mathrm{H}-\mathrm{NMR}$ (600 MHz, DMSO-d6) for $\mathbf{2 a 9}$

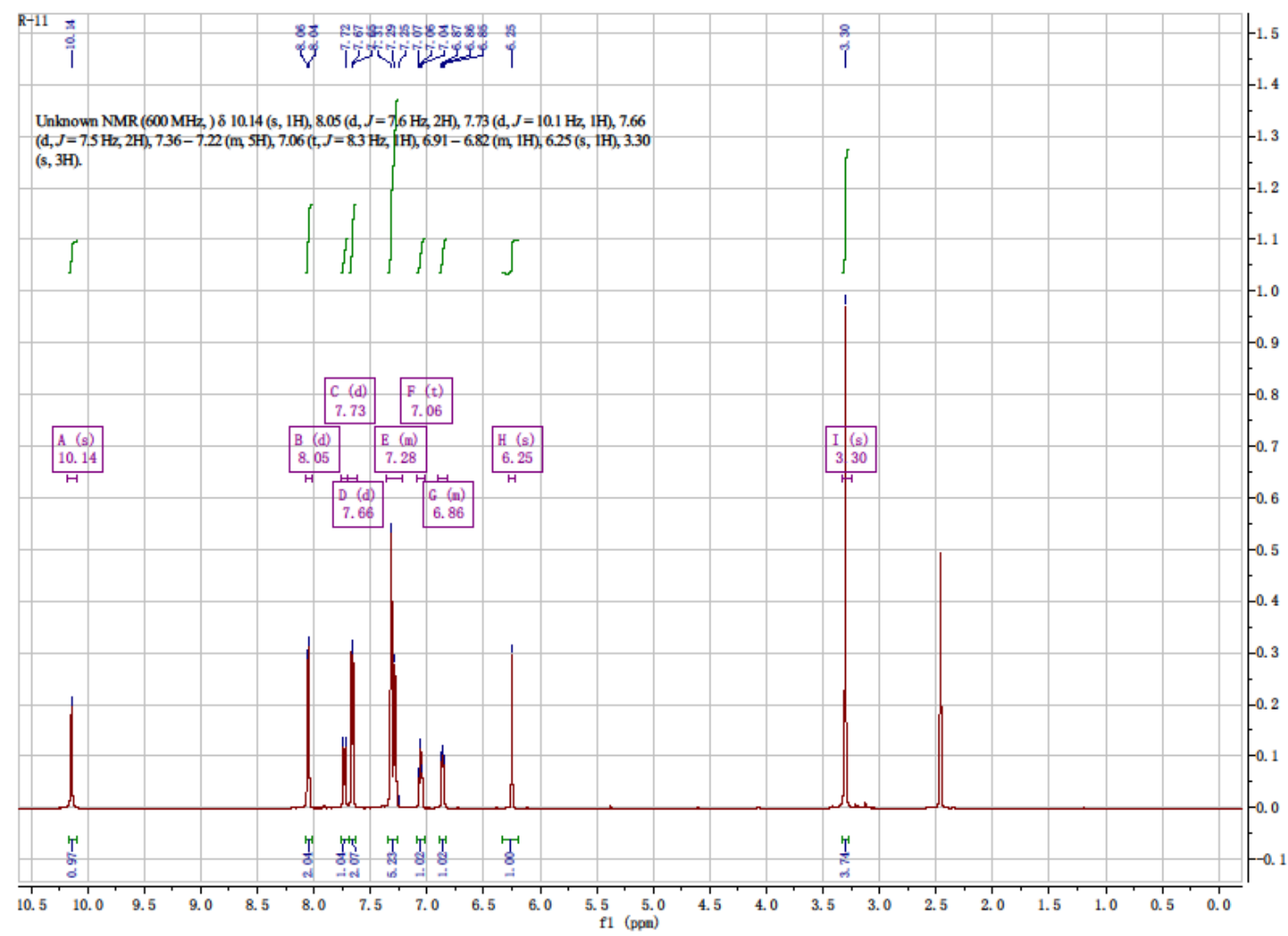

${ }^{13} \mathrm{C}-\mathrm{NMR}$ (151 MHz, DMSO-d6) for $\mathbf{2 a 9}$

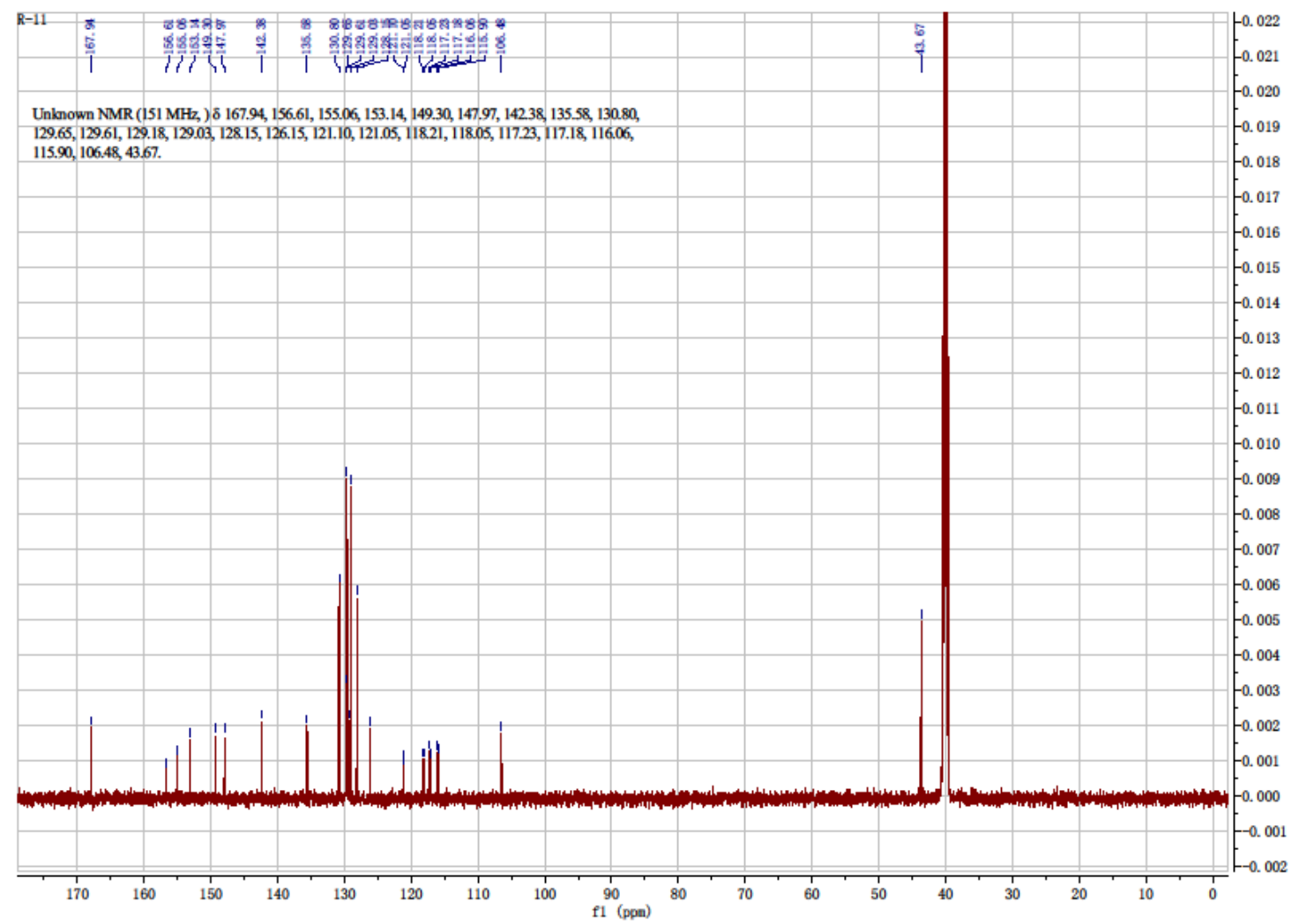


${ }^{1} \mathrm{H}-\mathrm{NMR}$ (600 MHz, DMSO-d6) for $\mathbf{2 a 1 0}$

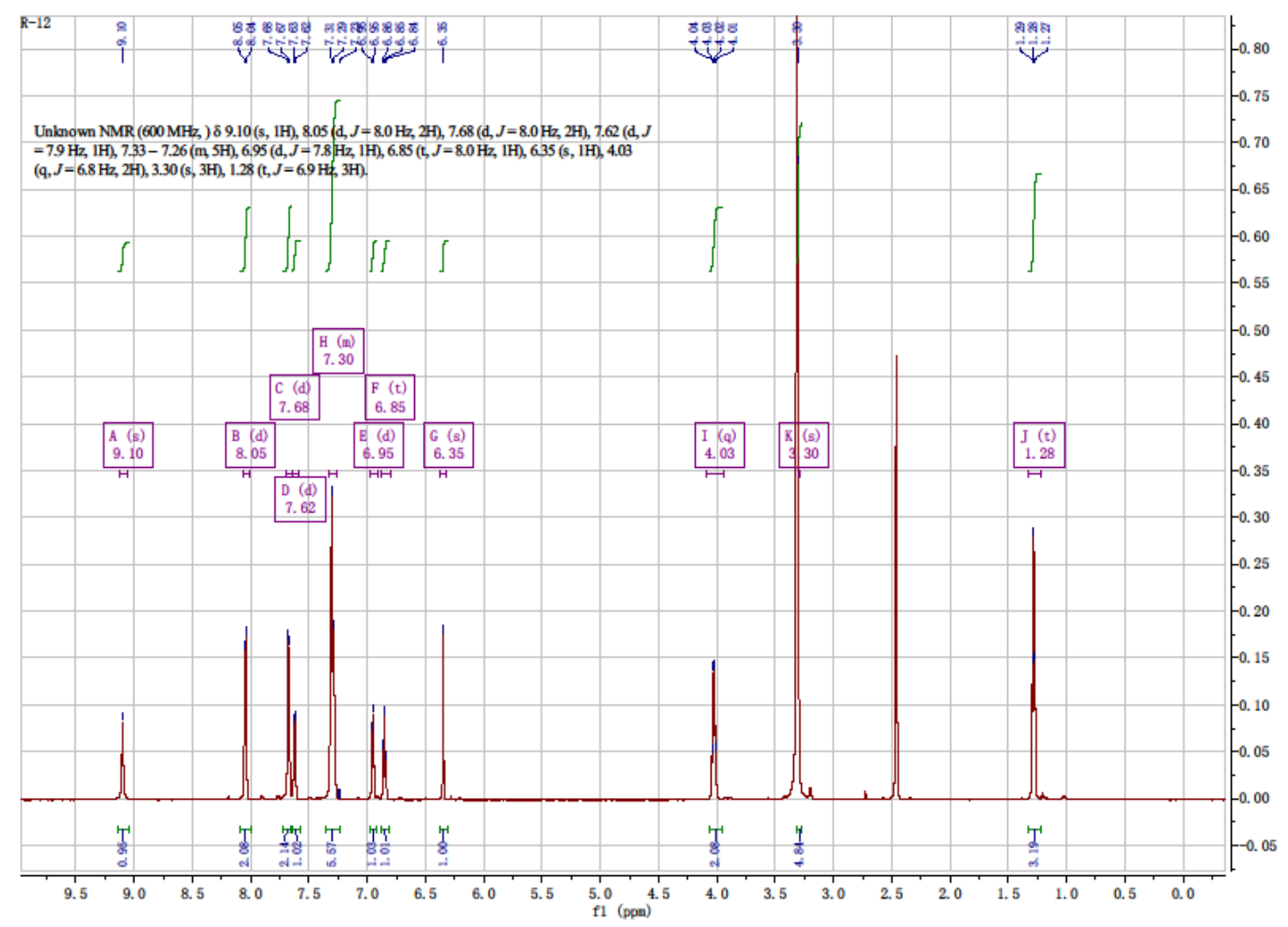

${ }^{13} \mathrm{C}-\mathrm{NMR}$ (151 MHz, DMSO-d6) for $\mathbf{2 a 1 0}$

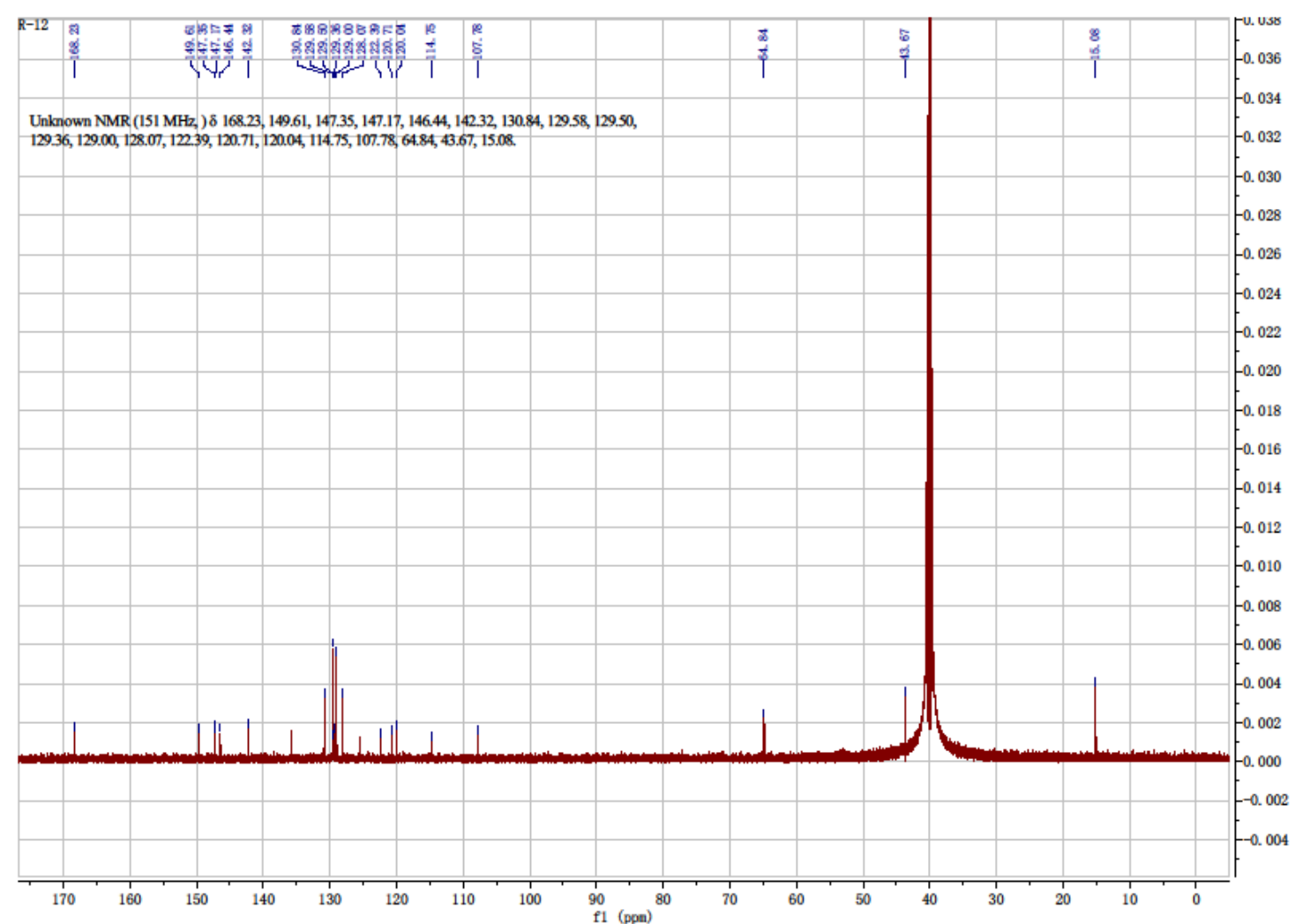


${ }^{1} \mathrm{H}-\mathrm{NMR}$ (600 MHz, DMSO-d6) for $\mathbf{2 a 1 1}$

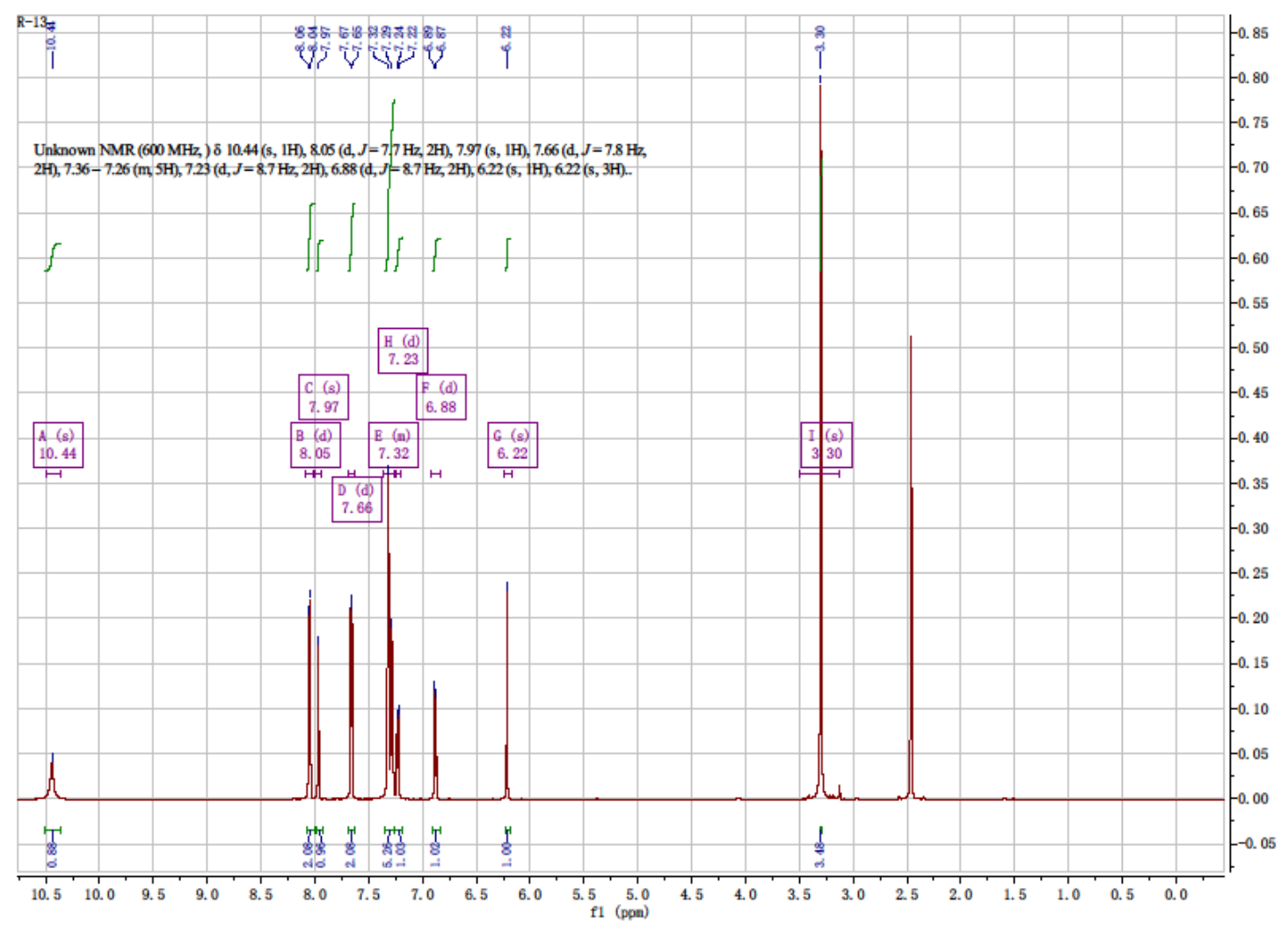

${ }^{13} \mathrm{C}-\mathrm{NMR}$ (151 MHz, DMSO-d6) for $\mathbf{2 a 1 1}$

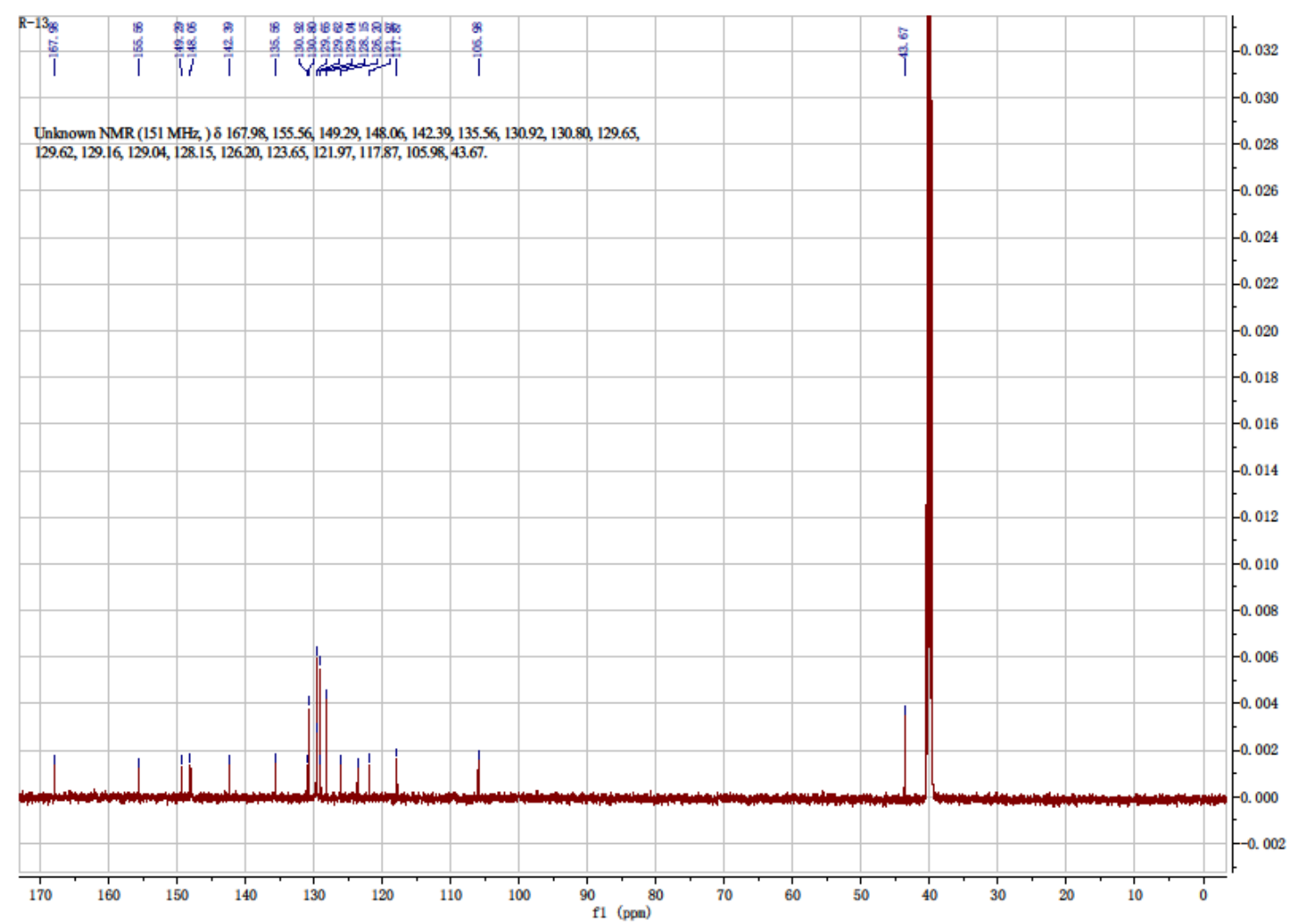


${ }^{1} \mathrm{H}-\mathrm{NMR}$ (600 MHz, DMSO-d6) for $\mathbf{2 a 1 2}$

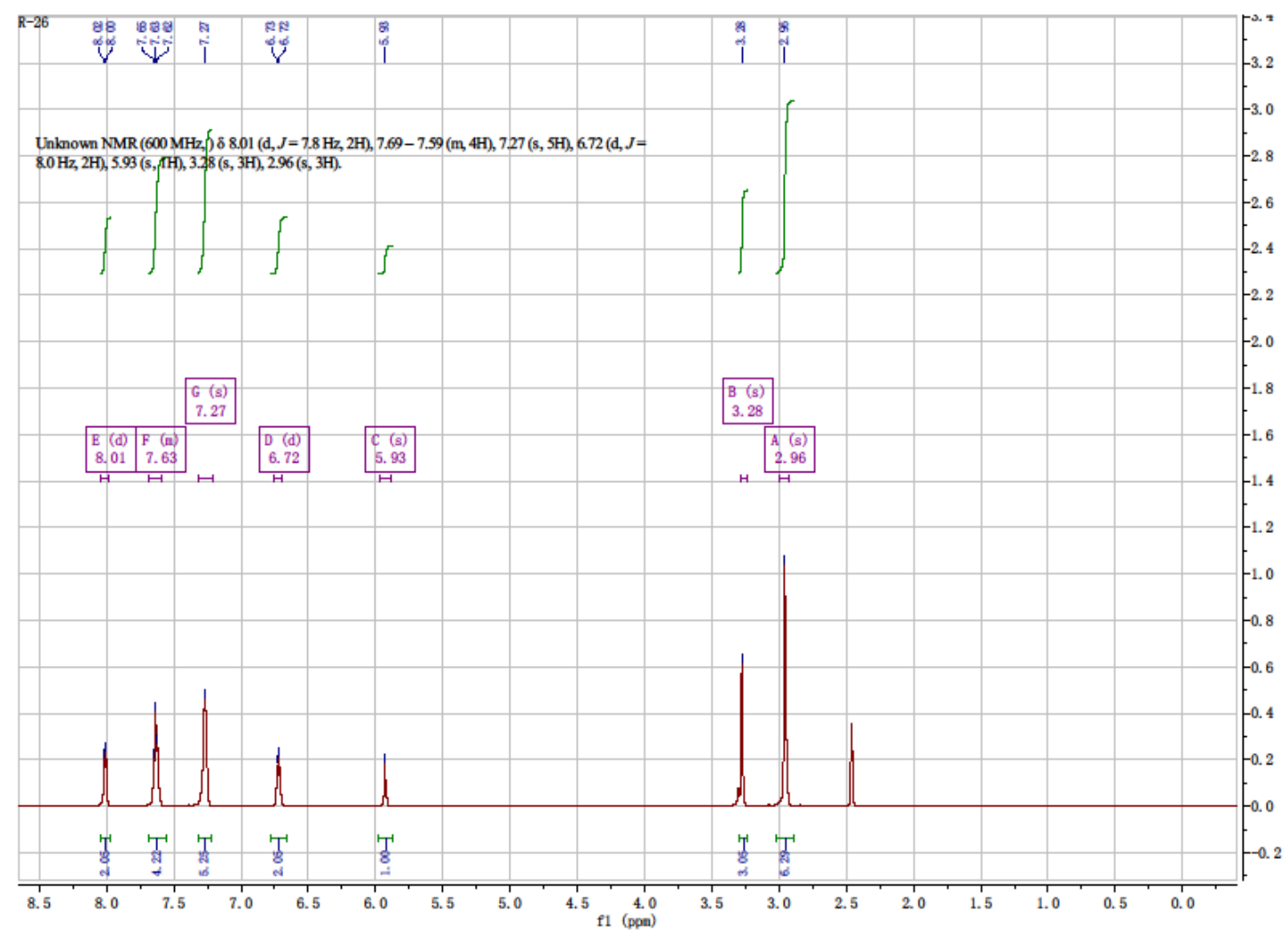

${ }^{13} \mathrm{C}-\mathrm{NMR}$ (151 MHz, DMSO-d6) for $\mathbf{2 a 1 2}$

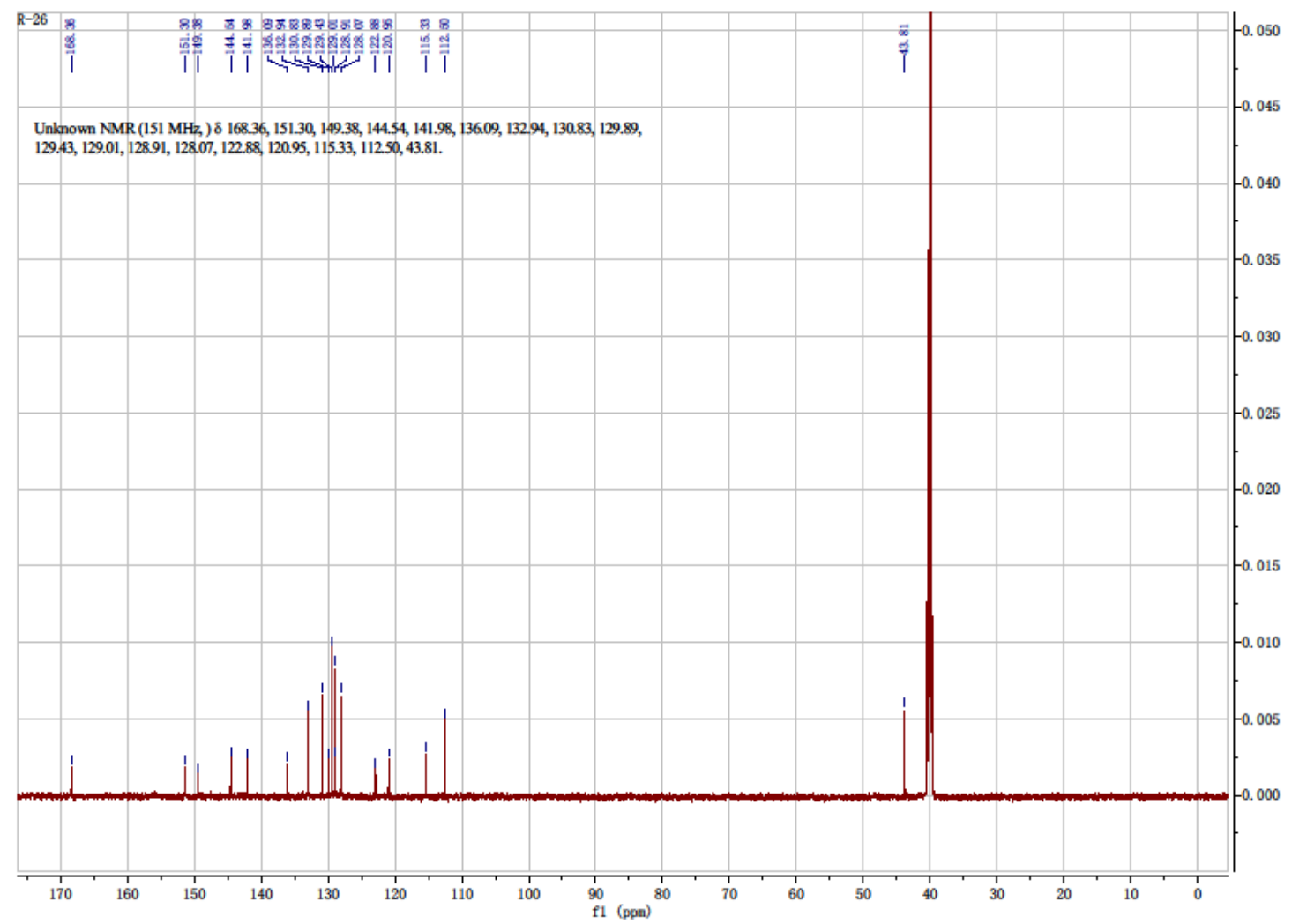


${ }^{1} \mathrm{H}-\mathrm{NMR}$ (600 MHz, DMSO-d6) for $\mathbf{2 a 1 3}$

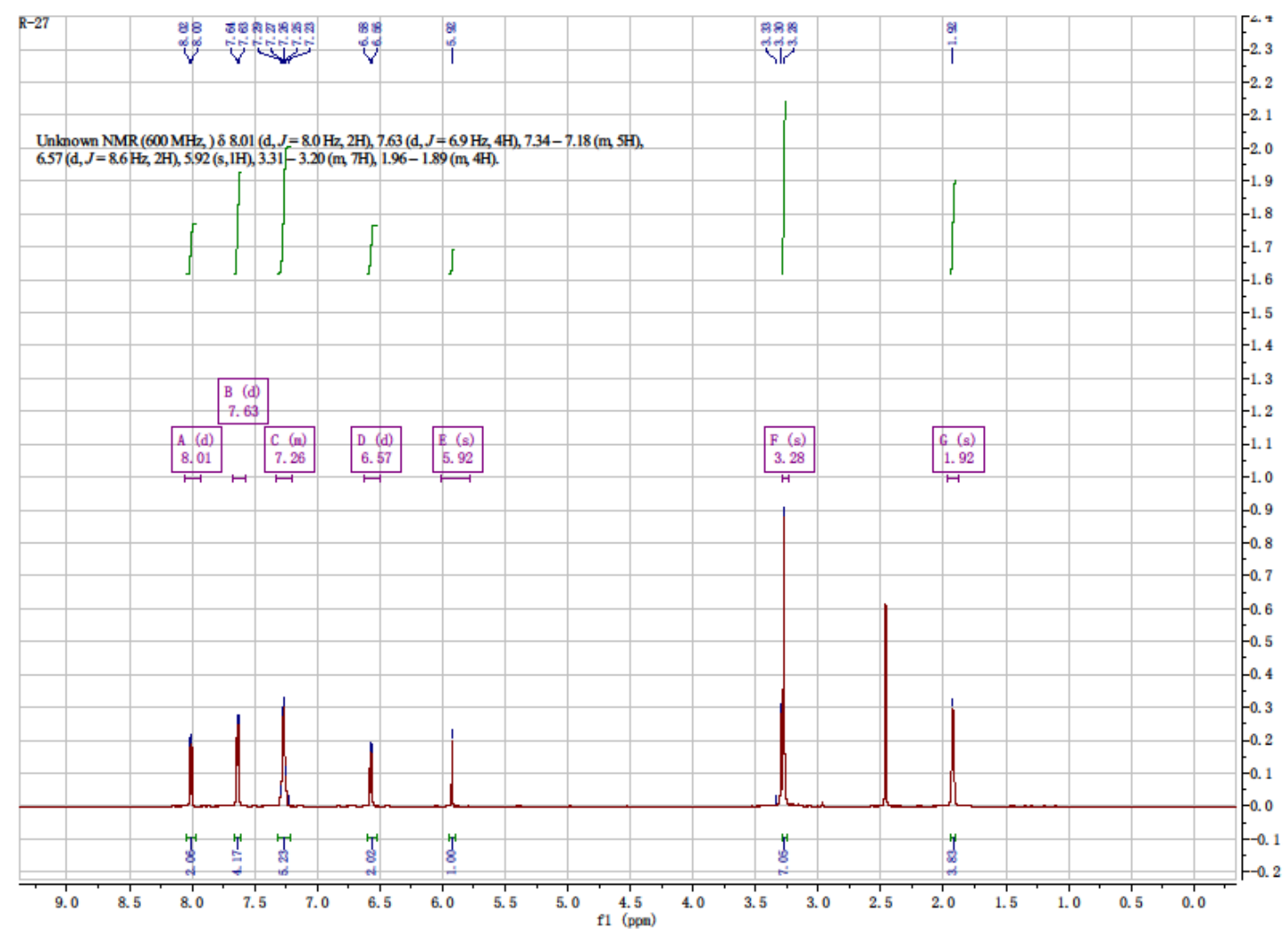

${ }^{13} \mathrm{C}-\mathrm{NMR}$ (151 MHz, DMSO-d6) for $\mathbf{2 a 1 3}$

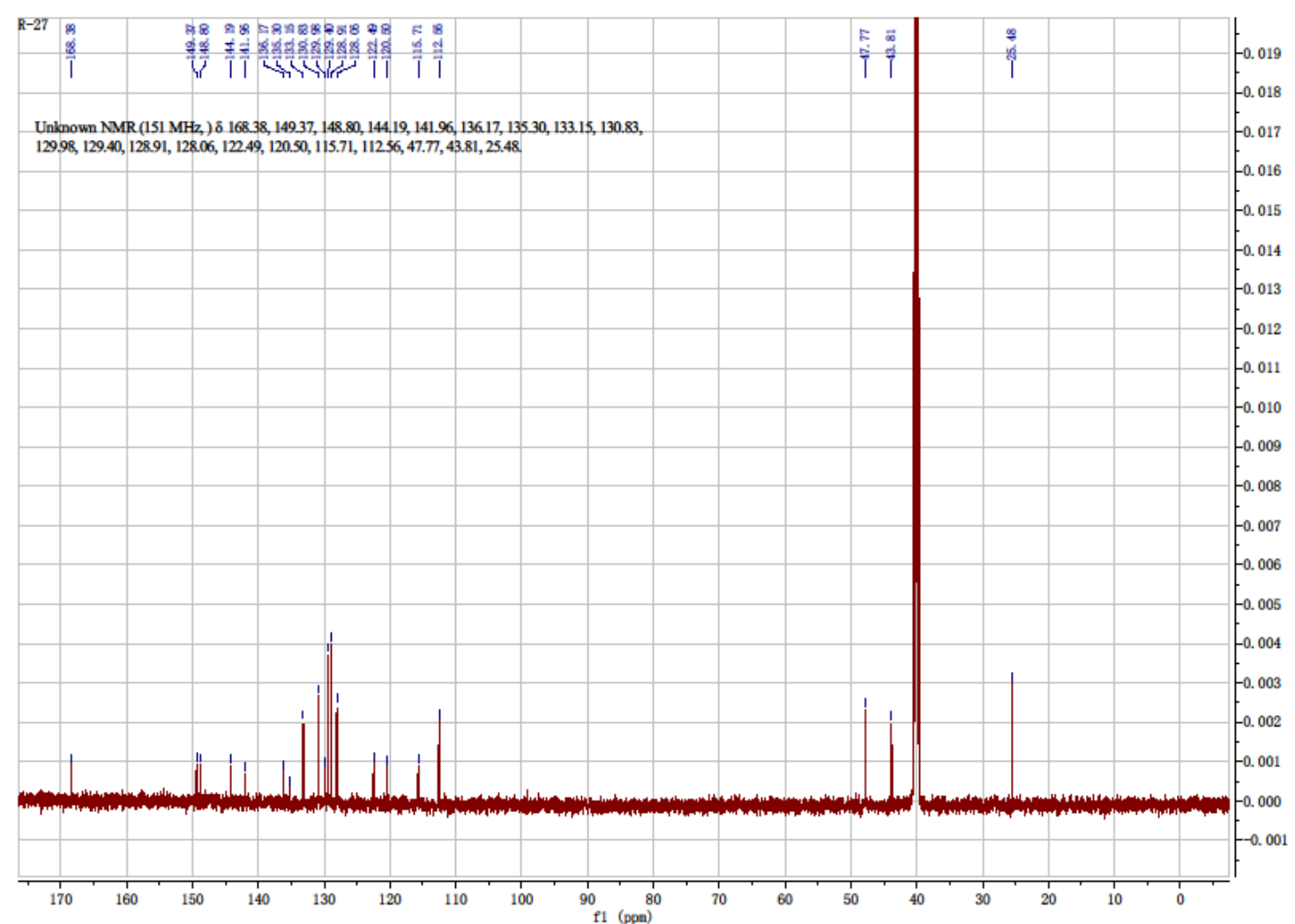


${ }^{1} \mathrm{H}-\mathrm{NMR}$ (600 MHz, DMSO-d6) for $\mathbf{2 a 1 4}$

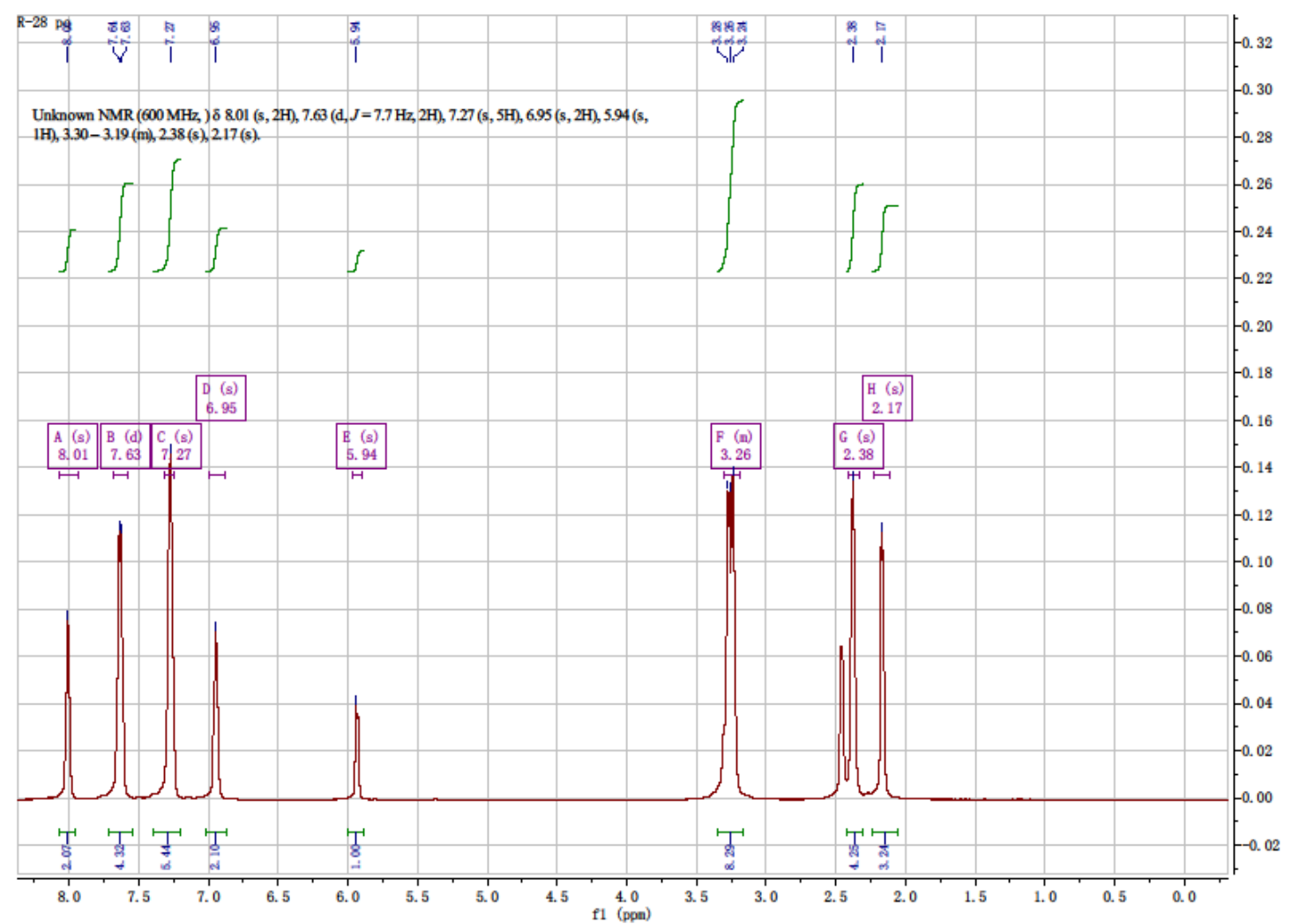

${ }^{13} \mathrm{C}-\mathrm{NMR}$ (151 MHz, DMSO-d6) for $\mathbf{2 a 1 4}$

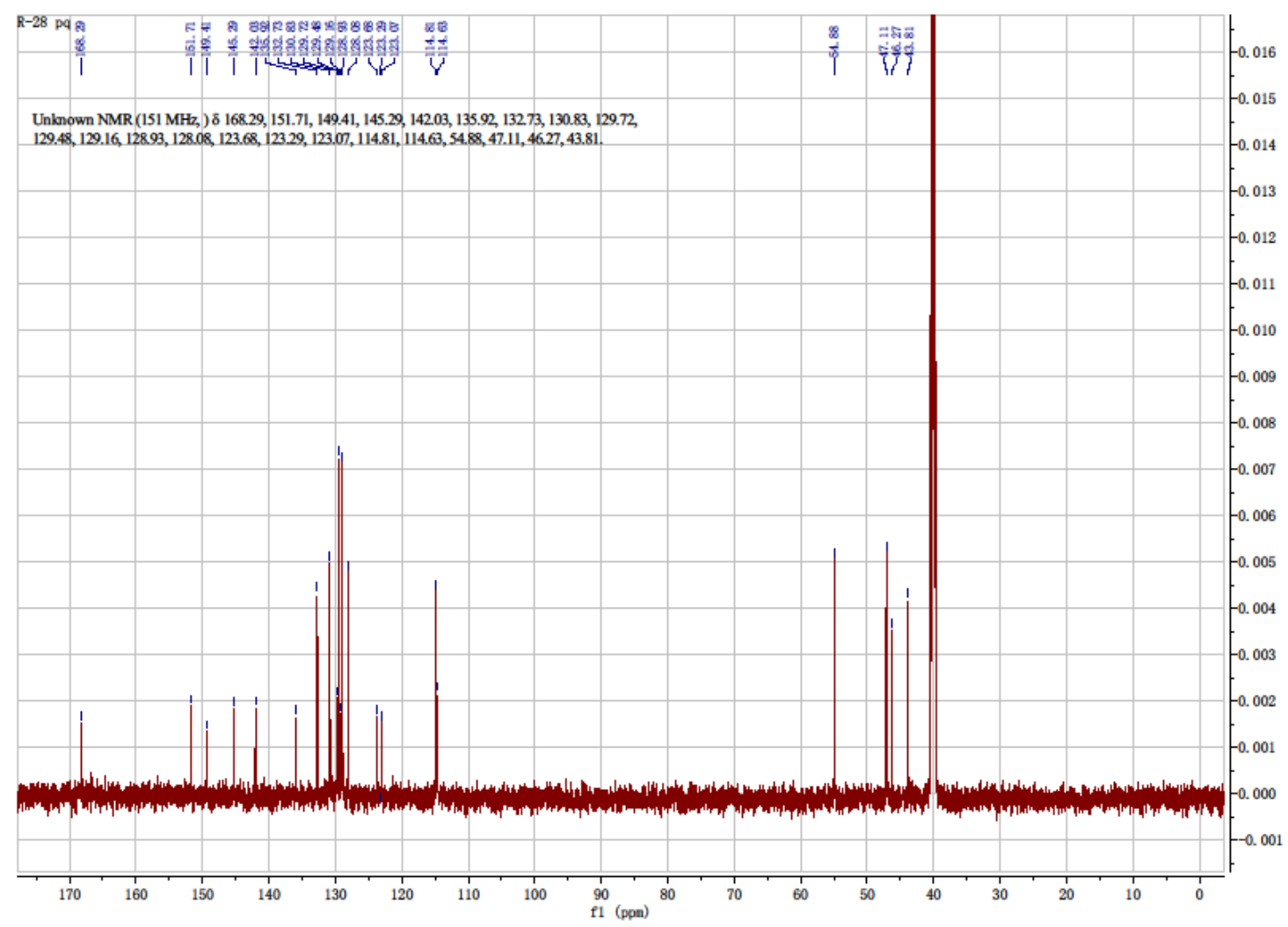


${ }^{1} \mathrm{H}-\mathrm{NMR}$ (600 MHz, DMSO-d6) for $\mathbf{2 a 1 5}$

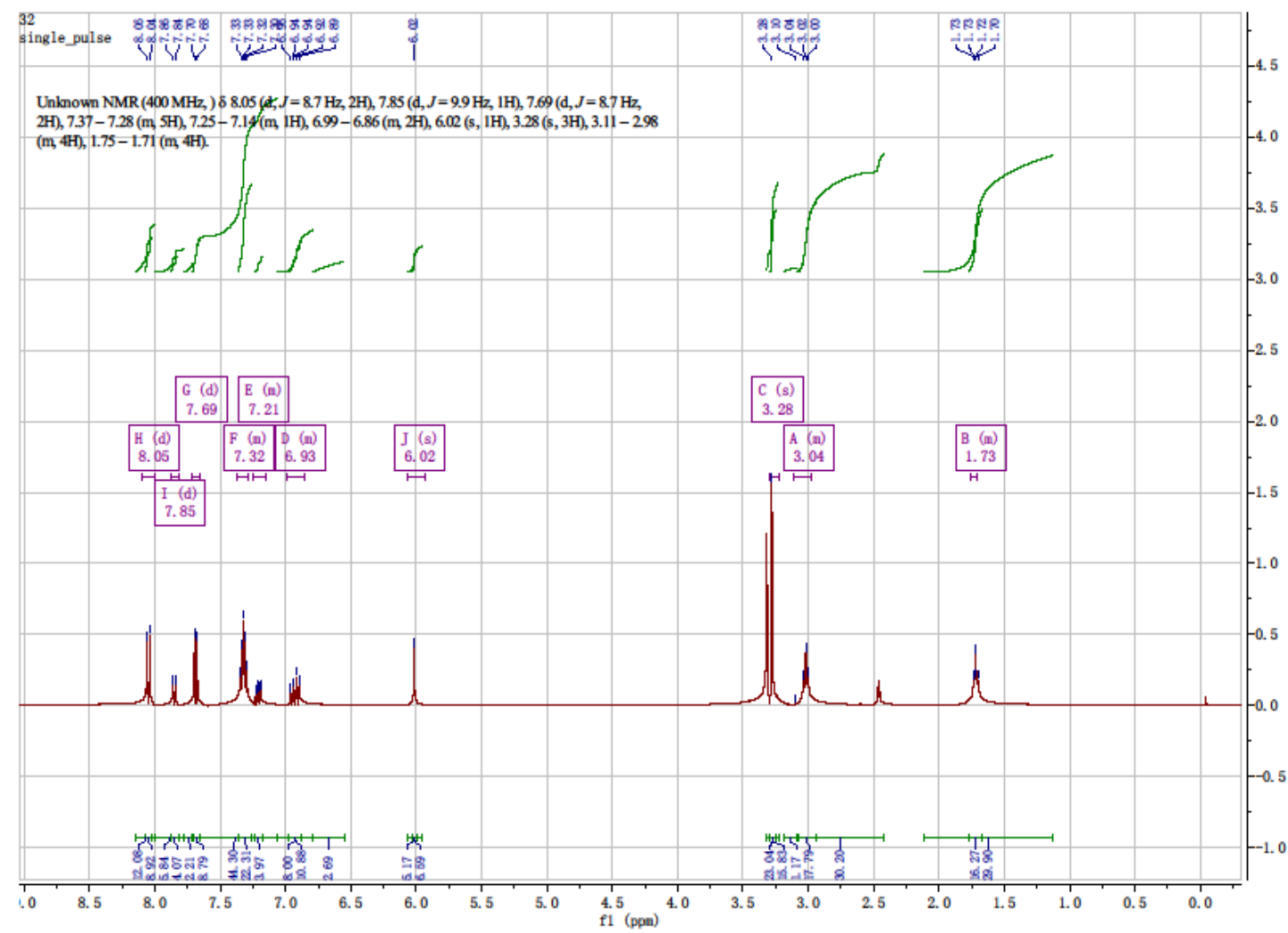

${ }^{13} \mathrm{C}-\mathrm{NMR}$ (151 MHz, DMSO-d6) for $\mathbf{2 a 1 5}$

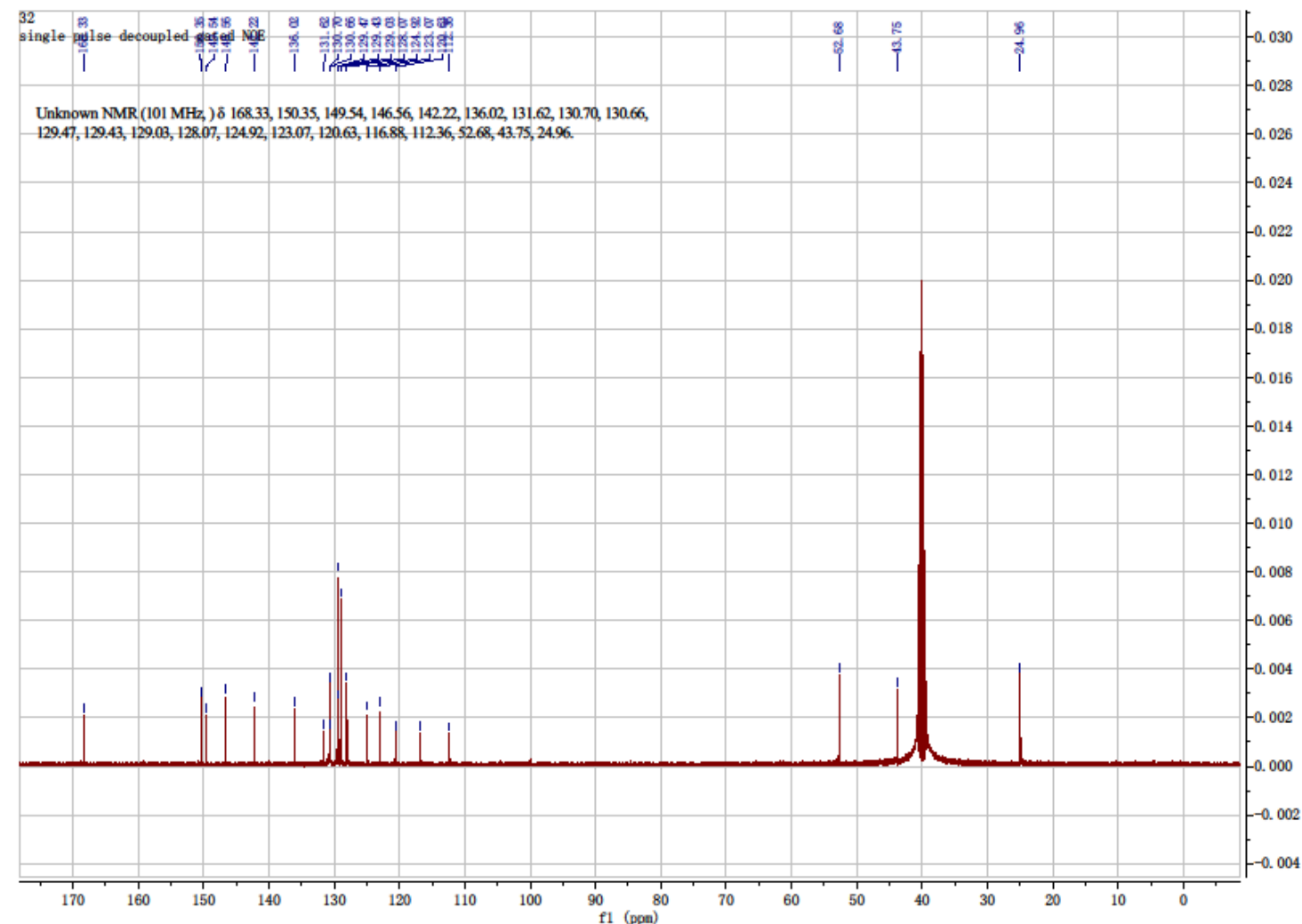


${ }^{1} \mathrm{H}-\mathrm{NMR}$ (600 MHz, DMSO-d6) for $\mathbf{2 a 1 6}$

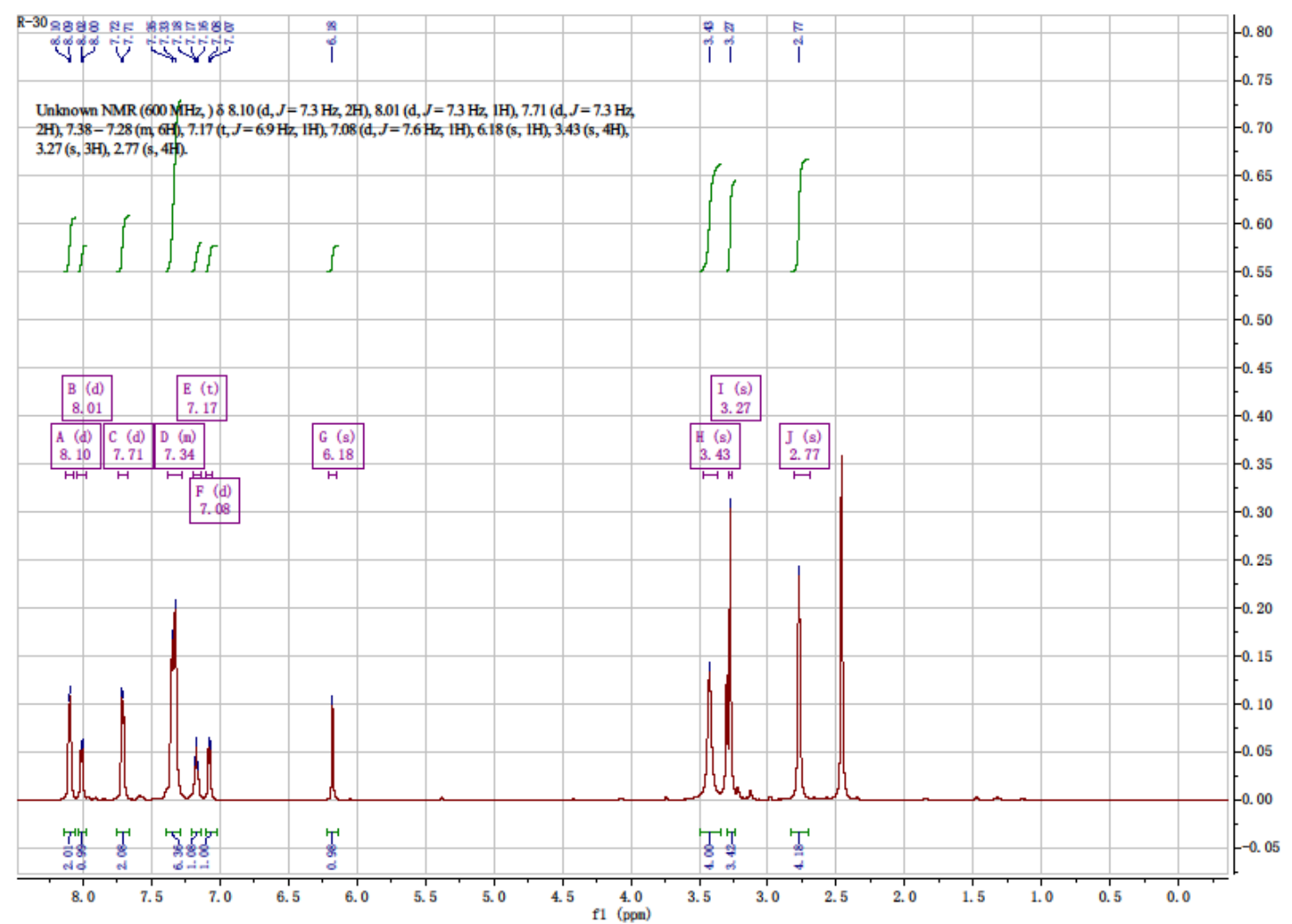

${ }^{13} \mathrm{C}-\mathrm{NMR}$ (151 MHz, DMSO-d6) for $\mathbf{2 a 1 6}$

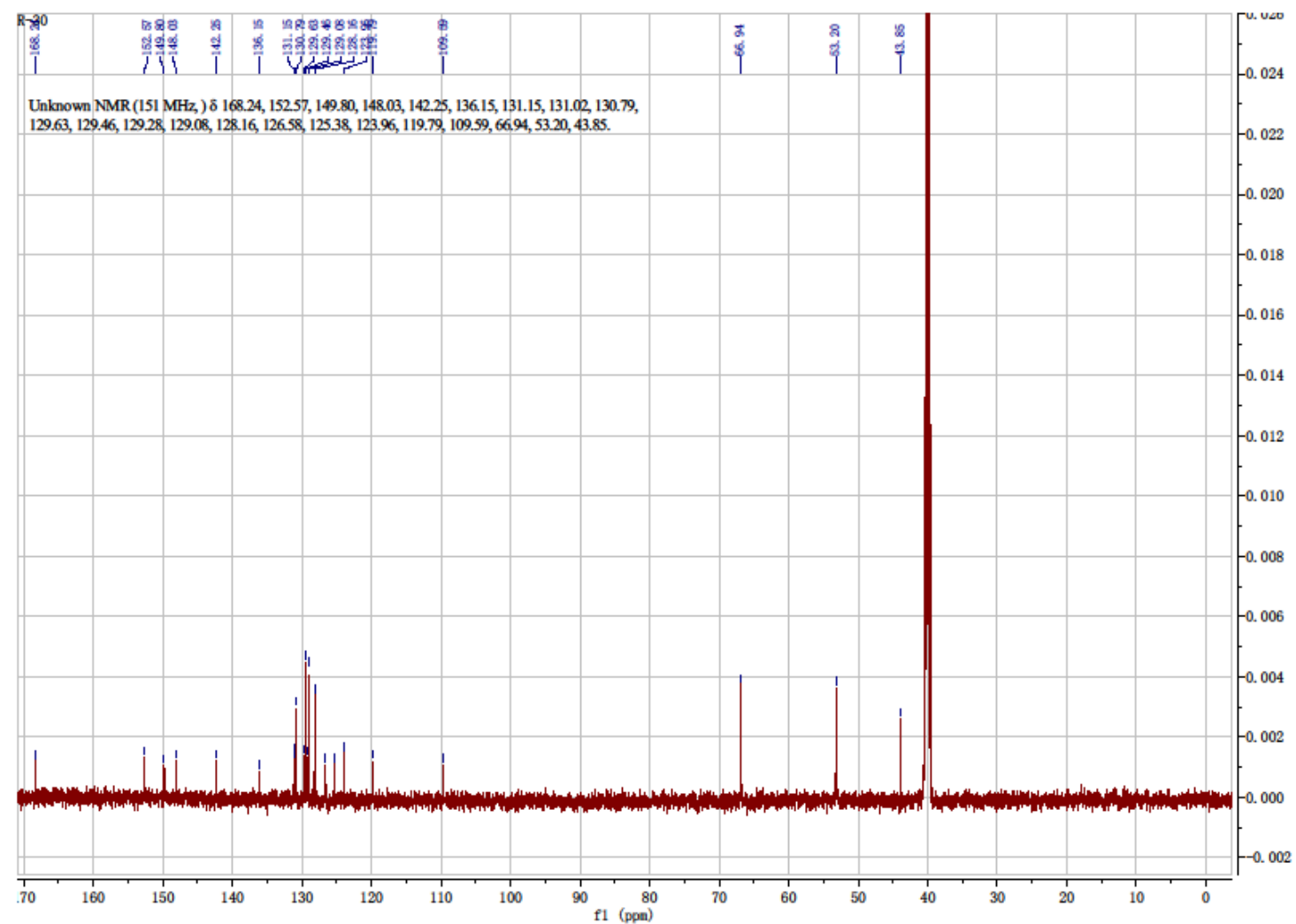


${ }^{1} \mathrm{H}-\mathrm{NMR}$ (600 MHz, DMSO-d6) for $\mathbf{2 a 1 7}$

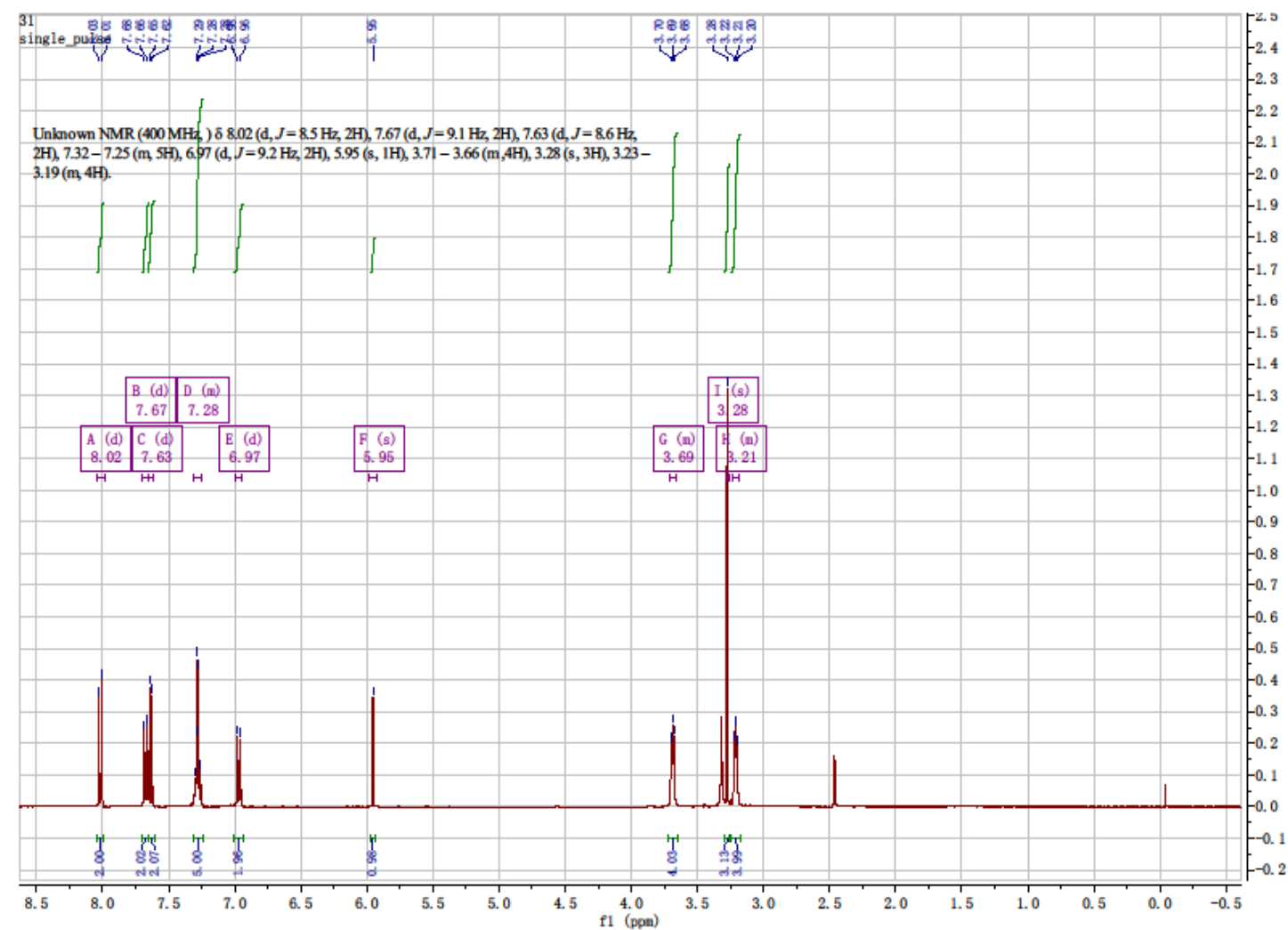

${ }^{13} \mathrm{C}-\mathrm{NMR}$ (151 MHz, DMSO-d6) for $\mathbf{2 a 1 7}$

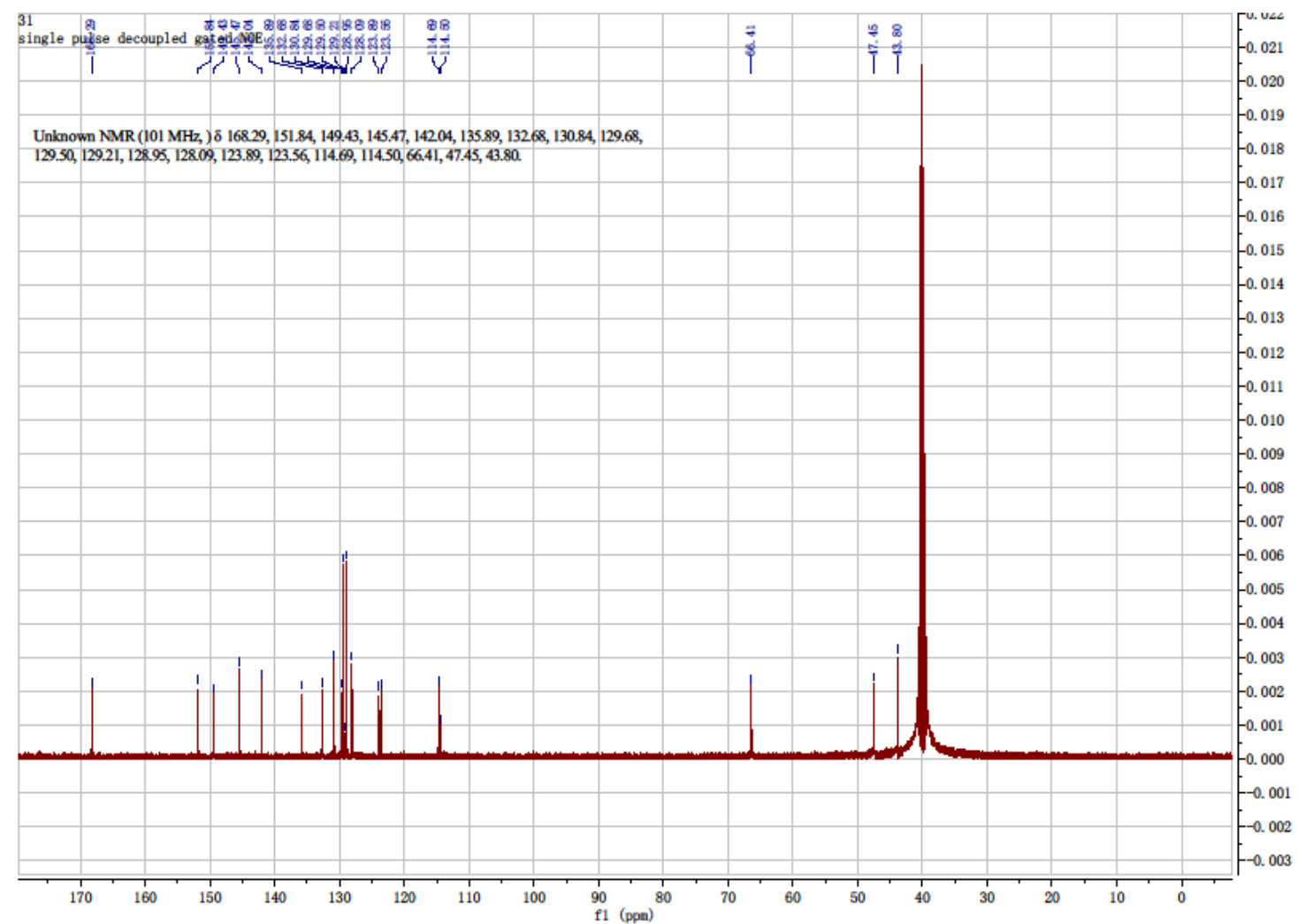


${ }^{1} \mathrm{H}-\mathrm{NMR}$ (600 MHz, DMSO-d6) for $\mathbf{2 b 1}$

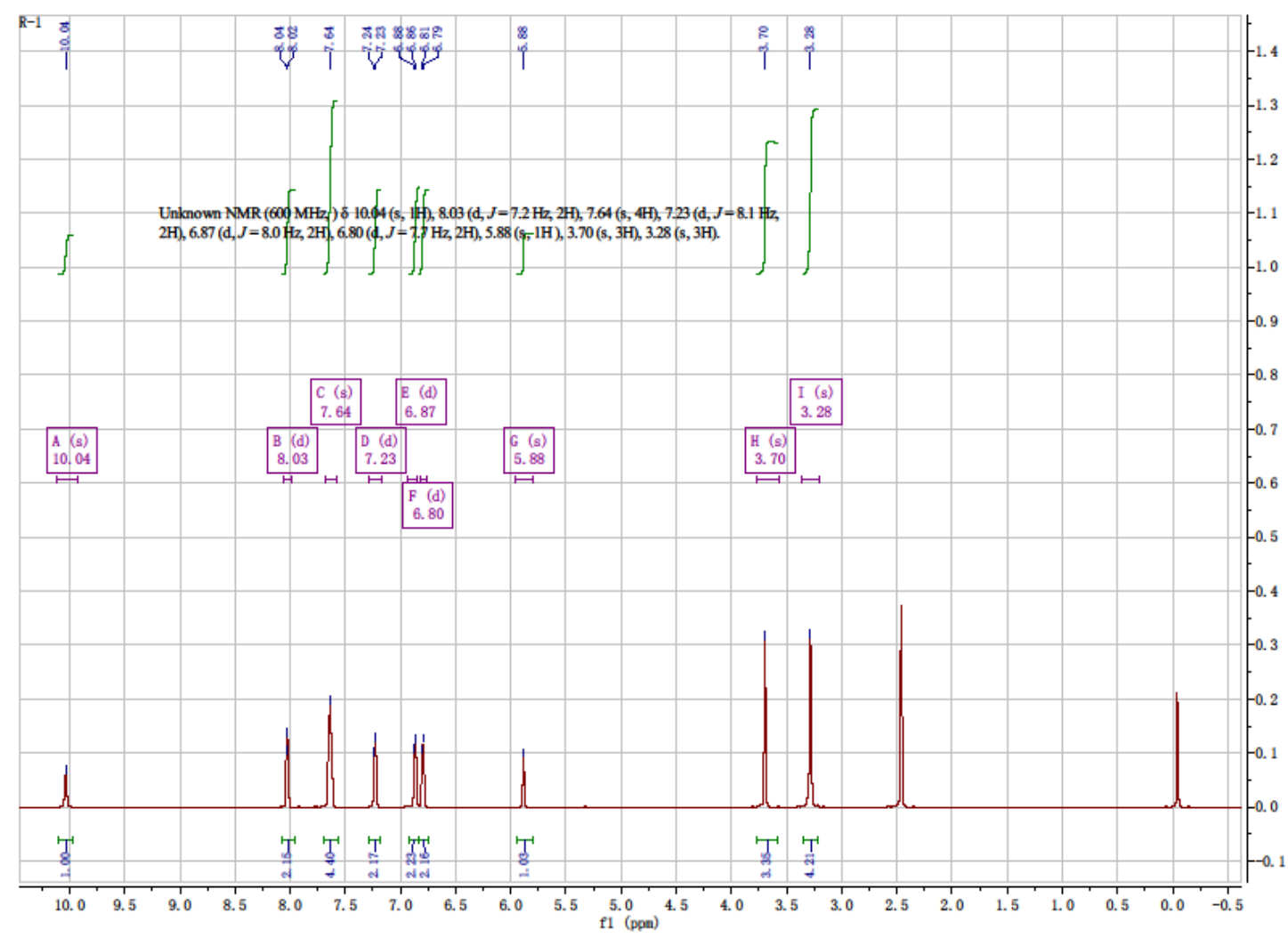

${ }^{13} \mathrm{C}-\mathrm{NMR}$ (151 MHz, DMSO-d6) for $\mathbf{2 b 1}$

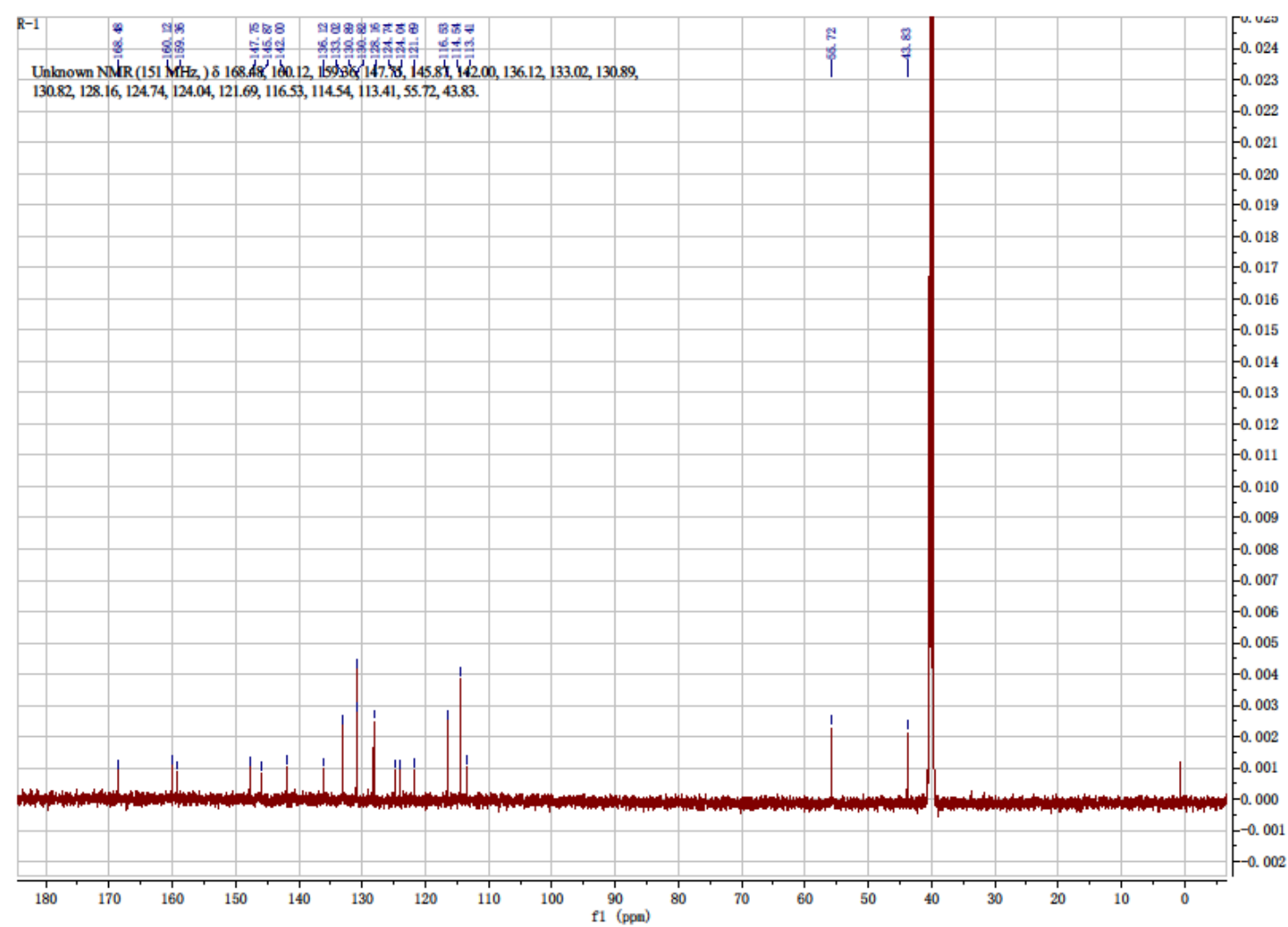


${ }^{1} \mathrm{H}-\mathrm{NMR}$ (600 MHz, DMSO-d6) for $\mathbf{2 b 2}$

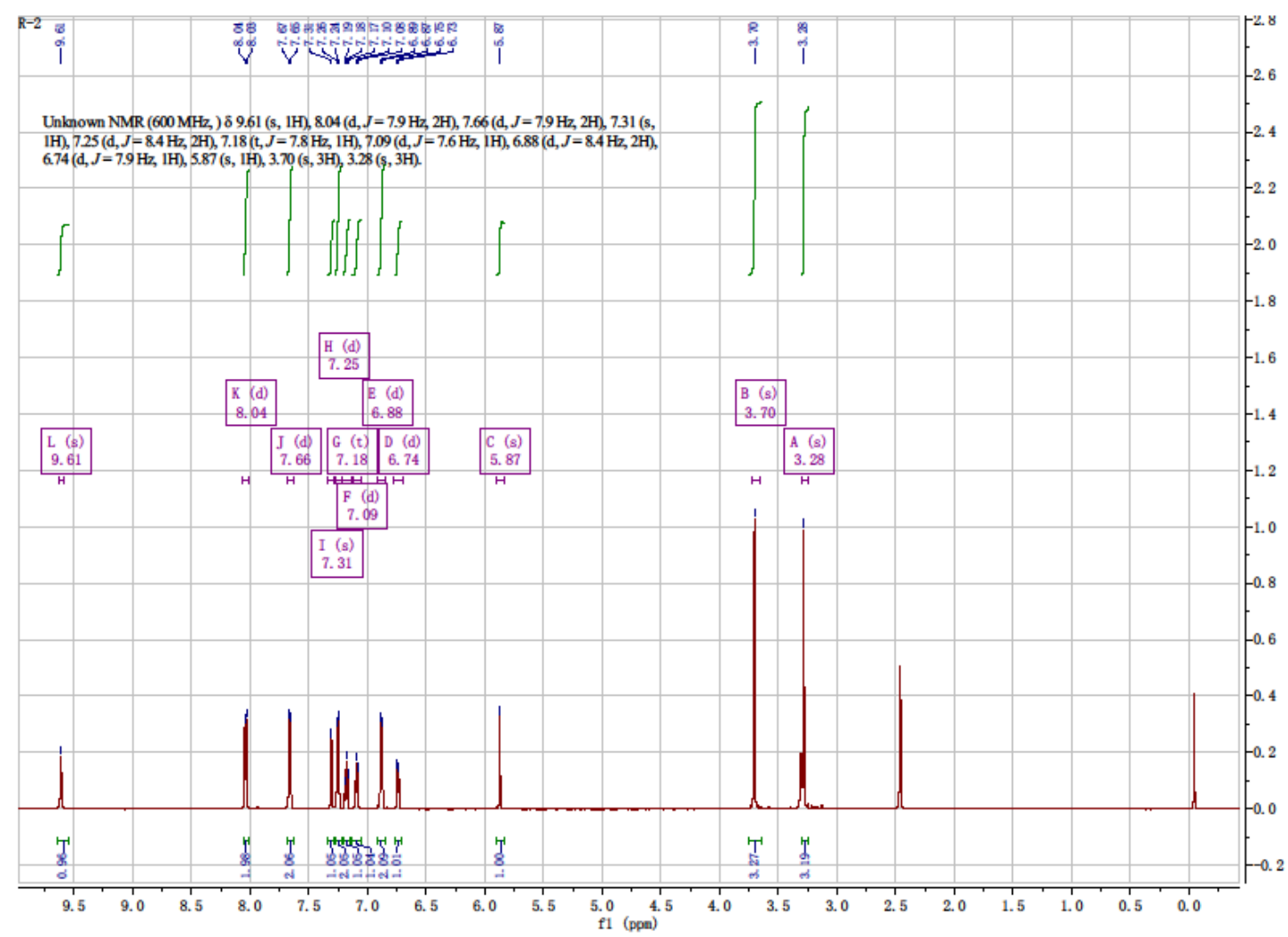

${ }^{13} \mathrm{C}-\mathrm{NMR}$ (151 MHz, DMSO-d6) for $\mathbf{2 b 2}$

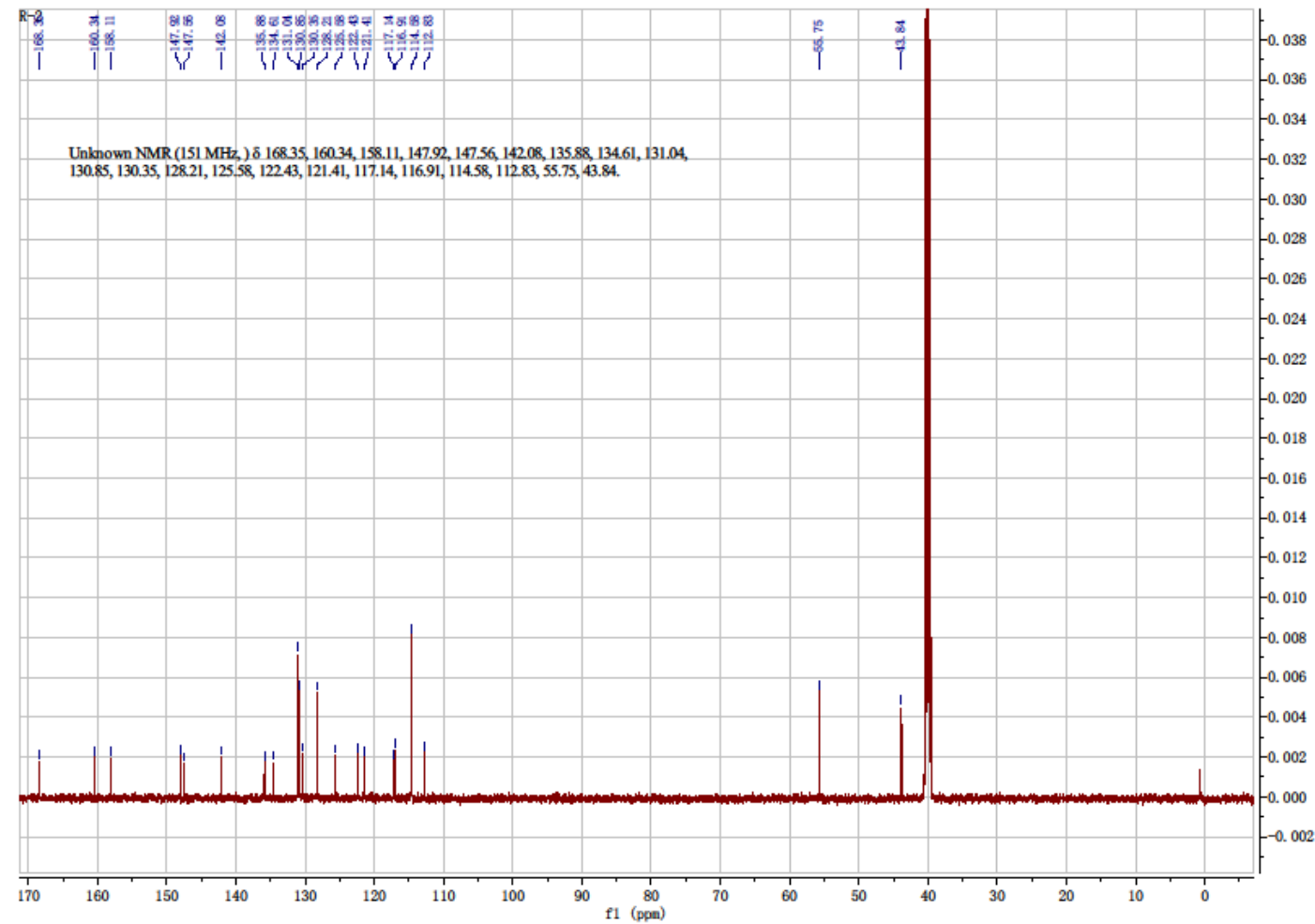


${ }^{1} \mathrm{H}-\mathrm{NMR}$ (600 MHz, DMSO-d6) for $\mathbf{2 b 3}$

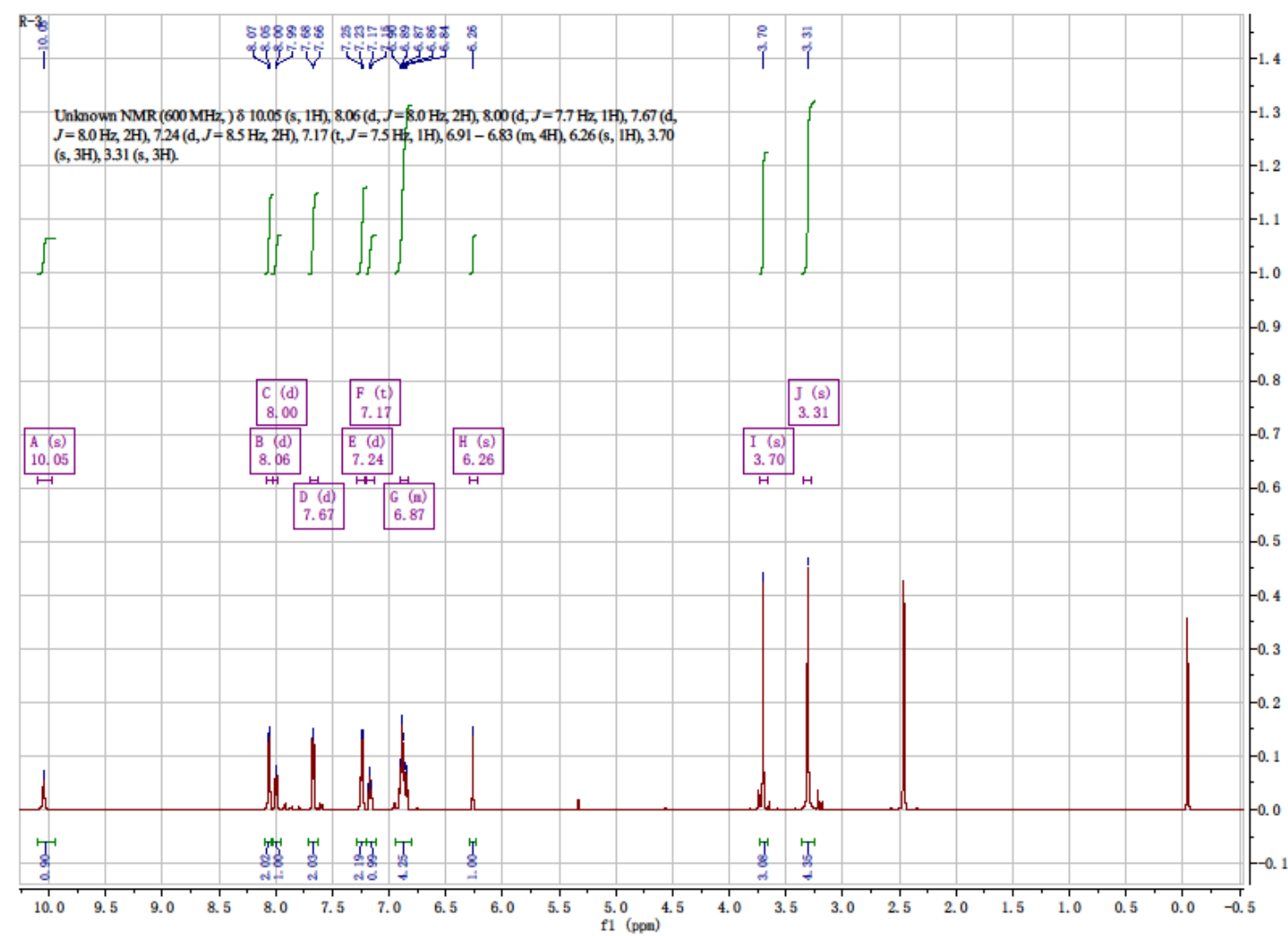

${ }^{13} \mathrm{C}-\mathrm{NMR}$ (151 MHz, DMSO-d6) for $\mathbf{2 b 3}$

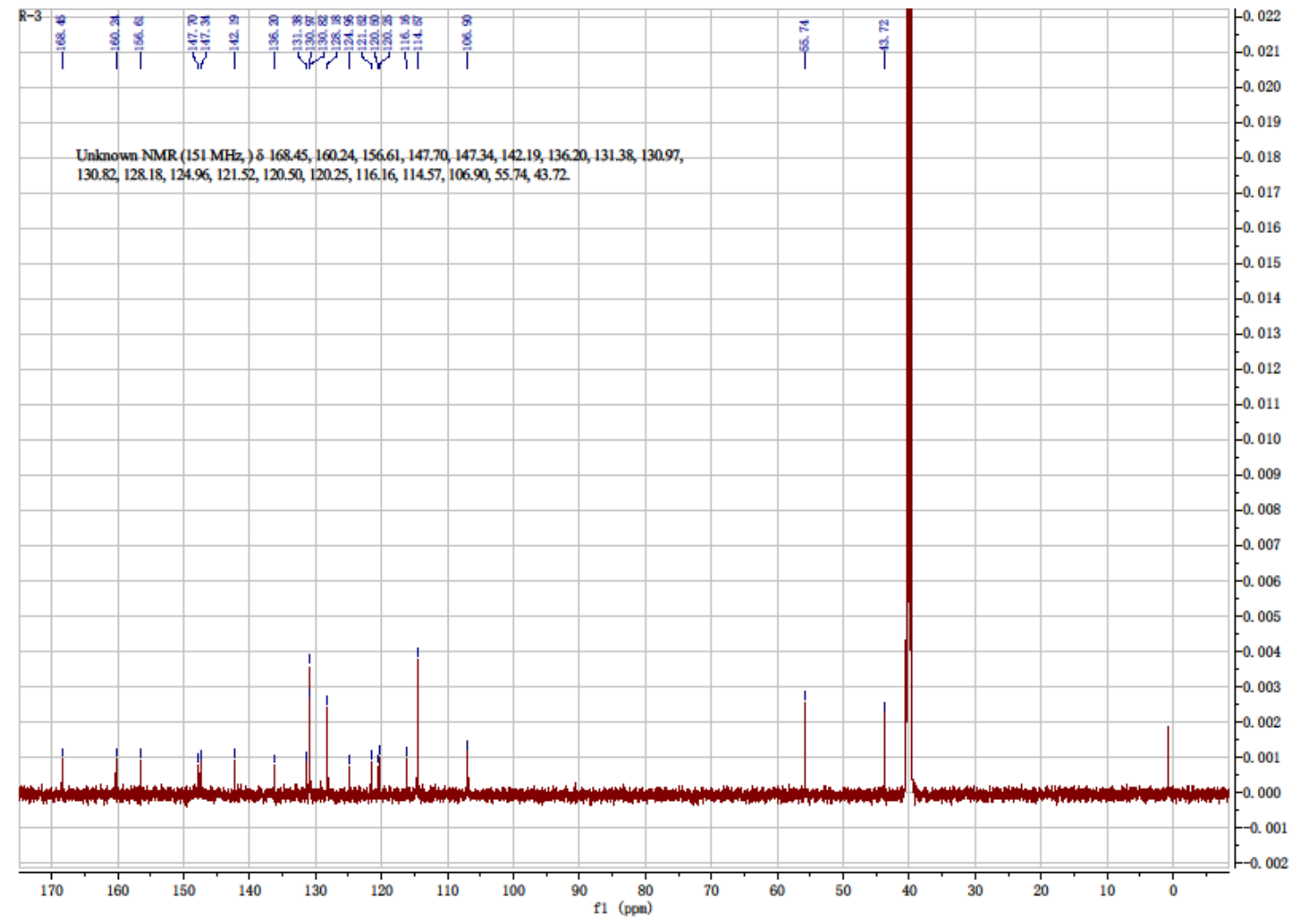




\section{References}

(1) Gaussian 09, Revision D.01, M. J. Frisch, G. W. Trucks, H. B. Schlegel, G. E. Scuseria, M. A. Robb, J. R. Cheeseman, G. Scalmani, V. Barone, B. Mennucci, G. A. Petersson, H. Nakatsuji, M. Caricato, X. Li, H. P. Hratchian, A. F. Izmaylov, J. Bloino, G. Zheng, J. L. Sonnenberg, M. Hada, M. Ehara, K. Toyota, R. Fukuda, J. Hasegawa, M. Ishida, T. Nakajima, Y. Honda, O. Kitao, H. Nakai, T. Vreven, J. A. Montgomery, Jr., J. E. Peralta, F. Ogliaro, M. Bearpark, J. J. Heyd, E. Brothers, K. N. Kudin, V. N. Staroverov, T. Keith, R. Kobayashi, J. Normand, K. Raghavachari, A. Rendell, J. C. Burant, S. S. Iyengar, J. Tomasi, M. Cossi, N. Rega, J. M. Millam, M. Klene, J. E. Knox, J. B. Cross, V. Bakken, C. Adamo, J. Jaramillo, R. Gomperts, R. E. Stratmann, O. Yazyev, A. J. Austin, R. Cammi, C. Pomelli, J. W. Ochterski, R. L. Martin, K. Morokuma, V. G. Zakrzewski, G. A. Voth, P. Salvador, J. J. Dannenberg, S. Dapprich, A. D. Daniels, O. Farkas, J. B. Foresman, J. V. Ortiz, J. Cioslowski, and D. J. Fox, Gaussian, Inc., Wallingford CT, 2013. 